Andrews University

Digital Commons @ Andrews University

1994

\title{
Premarital Education: A Model for the Toronto Perth Avenue Seventh-day Adventist Church
}

Steve David Cassimy

Andrews University

Follow this and additional works at: https://digitalcommons.andrews.edu/dmin

Part of the Practical Theology Commons

\section{Recommended Citation}

Cassimy, Steve David, "Premarital Education: A Model for the Toronto Perth Avenue Seventh-day Adventist Church" (1994). Professional Dissertations DMin. 158.

https://dx.doi.org/10.32597/dmin/158

https://digitalcommons.andrews.edu/dmin/158

This Project Report is brought to you for free and open access by the Graduate Research at Digital Commons @ Andrews University. It has been accepted for inclusion in Professional Dissertations DMin by an authorized administrator of Digital Commons @ Andrews University. For more information, please contact repository@andrews.edu. 


\section{Andrews \$university}

Seek Knowledge. Affirm Faith. Change the World.

Thank you for your interest in the

\section{Andrews University Digital Library of Dissertations and Theses.}

Please honor the copyright of this document by not duplicating or distributing additional copies in any form without the author's express written permission. Thanks for your cooperation. 


\section{INFORMATION TO USERS}

This manuscript has been reproduced from the microfilm master. UMI films the text directly from the original or copy submitted. Thus, some thesis and dissertation copies are in typewriter face, while others may be from any type of computer printer.

The quality of this reproduction is dependent upon the quality of the copy submitted. Broken or indistinct print, colored or poor quality illustrations and photographs, print bleedthrough. substandard margins, and improper alignment can adversely affect reproduction.

In the unlikely event that the author did not send UMI a complete manuscript and there are missing pages, these will be noted. Also, if unauthorized copyright material had to be removed, a note will indicate the deletion.

Oversize materials (e.g., maps, drawings, charts) are reproduced by sectioning the original, beginning at the upper left-hand comer and continuing from left to right in equal sections with small overlaps.

ProQuest Information and Learning 300 North Zeeb Road, Ann Arbor, Ml 48106-1346 USA 800-521-06C0

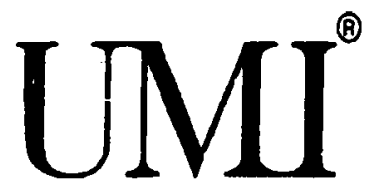


Reproduced with permission of the copyright owner. Further reproduction prohibited without permission. 


\begin{abstract}
PREMARITAL EDUCATION: A MODEL FOR THE TORONTO PERTH AVENUE SEVENTH-DAY ADVENTIST

CHURCH
\end{abstract}

\author{
by
}

Steve David Cassimy

Adviser: Dr. James J. North, Jr. 


\section{ABSTRACT OF GRADUATE STUDENT RESEARCH}

A Project Report

Andrews University Seventh-day Adventist Theological Seminary

Title: PREMARITAL EDUCATION: A MODEL FOR THE TORONTO PERTH AVENUE SEVENTH-DAY ADVENTIST CHURCH

Name of researcher: Steve David Cassimy

Name and degree of faculty adviser: James J. North, Jr., D.Min.

Date completed: June 1994

Statement of Project

Every pastor is involved in performing marriages.

Pastors are also spending a considerable amount of time in post-marital counseling. This project sought to design and implement a Premarital Education program to help prepare couples for marriage and to reduce the number of hours pastors spend with post-marital care.

The sessions in the model may prepare couples for life's challenges as they learn to develop communication and coping skills. It is hoped the sessions will aid the couple in handling marital adjustment and in dealing with conflict. 


\section{Method}

This project report explores a brief history of Premarital Education in the Seventh-day Adventist Church and then examines the current status. Ten metropolitan Toronto church pastors helped in gathering this data.

With the aid of biblical resources and the spirit of Prophecy, a theological base is set forth in the context of Premarital Education.

At the conclusion of the project, a model is presented as a program for the Toronto Perth Avenue Seventh-day Adventist Church. It is hoped that pastors will use this model as a springboard for developing their own models.

\section{Conclusion}

Preparation is an obvious theme in scripture. The pastor/shepherd must follow this motif as he/she prepares couples for a lifelong covenant. The results of the evaluation confirm the theory that pastors must use a proven and tried premarital program before marrying a couple. The evaluation also suggests that a premarital program may be a contributing factor in resolving some of the problems in dysfunctional marriages. The couples of the Pertr: Avenue Seventh-day Adventist Church who received premarital education have benefitted enormously from this project. 


\author{
Andrews University \\ Seventh-day Adventist Theological Seminary
}

\author{
PREMARITAL EDUCATION: A MODEL FOR \\ THE TORONTO PERTH AVENUE \\ SEVENTH-DAY ADVENTIST \\ CHURCH
}

\author{
A Project Report \\ Presented in Partial Fulfillment \\ of the Requirements for the Degree \\ Doctor of Ministry
}

by

Steve David Cassimy

June 1994

Reproduced with permission of the copyright owner. Further reproduction prohibited without permission. 
UMI Number: 3096436

\section{$\mathrm{UMI}$}

UMI Microform 3096436

Copyright 2003 by ProQuest Information and Learning Company.

All rights reserved. This microform edition is protected against unauthorized copying under Title 17, United States Code.

\section{ProQuest Information and Learning Company 300 North Zeeb Road \\ P.O. Box 1346 \\ Ann Arbor, Ml 48106-1346}




\title{
PREMARITAL EDUCATION: A MODEL FOR THE TORONTO PERTH AVENUE SEVENTH-DAY ADVENTIST CHURCH
}

\begin{abstract}
A project report
presented in partial fulfillment of the requirements for the degree Doctor of Ministry
\end{abstract}

by

Steve David Cassimy

APPROVAL BY THE COMMITTEE:
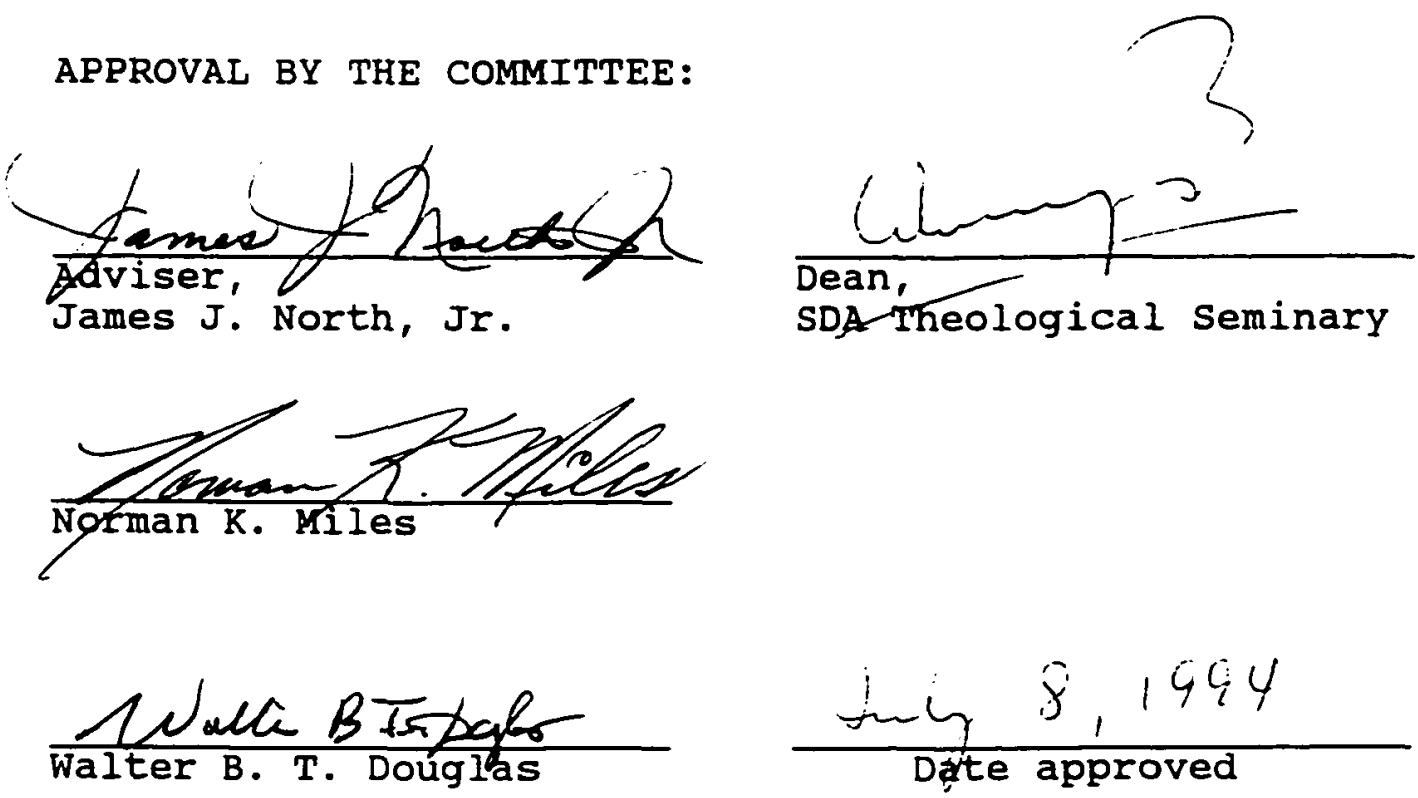


\section{ACKNOWLEDGEMENTS}

This project would have been impossible to complete without the love, understanding, and care of my dearest wife, Marilyn. I also express appreciation to David and Lavona, who for many months saw Dad only on the weekends but did not complain. The Toronto Perth Avenue Seventh-day Adventist Church family has been a strong source of support, and I express thanks to every member. The ontario Conference of Seventh-day Adventists has been a strong supporter during this project.

I wish to express thanks to the following individuals: My associates in ministry, especially Vincent Lue, Ishmael Ali, and Winston Simpson; Elders Orville Parchment and Rick Bacchus; Dr. James J. North, Jr., my chairman, Dr. Norman K. Miles, and Dr. Walter B. T. Douglas, who not only gave their time but also their support; to Jan Higgins, whose encouragement was outstanding; to Bonnie Beres, Marilyn Cassimy, Paulette McLean, Judy Burgin-Hall, Heather Dunkley, and Hillary Beckford for their secretarial input.

But best of all, I thank God by whose grace and blessed assurance this project was completed. 
TABLE OF CONTENTS

ACKNOWLEDGEMENTS . . . . . . . . . . . . . . . . . i

Chapter

I. INTRODUCTION . . . . . . . . . . . . . . . . . 1

Purpose of the Project... . . . . . . . . . 1

Justification of the Project. . . . . . . . . 1

Limitation of the Project . . . . . . . . . . 9

Definition of Terms . . . . . . . . . . 10

II. BRIEF HISTORY AND CURRENT STATUS OF PREMARITAL

EDUCATION IN THE SEVENTH-DAY ADVENTIST

DENOMINATION IN HISTORICAL SEQUENCE . . . . . . 11

Dr. Colin Standish . . . . . . . . . . . 11

General Conference in Vienna, $1975 . . . . .212$

Adventist Engaged Encounter . . . . . . . . 18

Pat Morrison's Open-ended Questionnaire . . . 20

General Conference Committee Actions . . . . . 21

Togetherness, Oneness, Joy . . . . . . . . . 21

245-84NG Premarriage Education .. . . . . . . 22

An Alphabetical Listing of Current

Non-Seventh-day Adventist Premarriage

Education . . . . . . . . . . . . . 23

Before You Say I Do............. 23

The Prepare-Enrich Program . . . . . . . . 24

Sixteen Personality Factors . . . . . . . 26

Sex Knowledge Inventory . . . . . . . . . 26

Taylor-Johnson Temperament Analysis . . . 27

H. Norman Wright . . . . . . . . . . 27

What Is Being Done by Ten Churches in the

The Questionnaire . . . . . . . . . . . 30

Summary of the Questionnaire . . . . . . . . 33

III. TOWARD A THEOLOGY OF MARRIAGE AND MARRIAGE

PREPARATION . . . . . . . . . . . . . . . . . . 34

A Biblical Definition of Marriage . . . . . 34

Brief Overview of the Church's Involvement

in Premarital Education ......... 37

Premarital Education Before

World War II....... . . . . 37

ii

Reproduced with permission of the copyright owner. Further reproduction prohibited without permission. 
Premarital Education After

World War II . . . . . . . . . . . . . 42

Biblical Principles ..... . . . . . . . . 43

Three Reasons for Marriage . . . . . . . . . . 45

The Permanency of Marriage .. . . . . . . . . 46

Shepherding in the context of

Premarital Education . . . . . . . . . . 48

Saving Time in the context of

Premarital Education .......... 51

Understanding Responsibilities in . . . . 52

The Importance of Preparation . . . . . . . 54

Spirit of Prophecy Support for

Preparation ............. 62

IV. THE MODEL . . . . . . . . . . . . . . 69

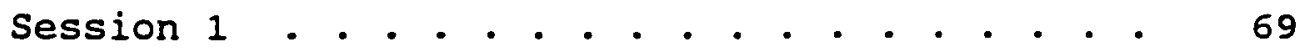

Marriage Information Sheet . . . . . . . 69

Guidelines for Wedding Ceremony . . . . . . 72

Session 2 . . . . . . . . . . . . . . . . . . 74

Session 3 . . . . . . . . . . . . . . . . . . 77

Before You Say I Do... . . . . . . . . . 77

Session 4 . . . . . . . . . . . . . . . . . 78

Reading Assignments . . . . . . . . . . . 78

Guidelines for Planning Your Wedding . . . 80

The Bride's Calendar . . . . . . . . . . . 83

The Groom's Checklist . . . . . . . . . . . 83

Sessions 5-8 (Individual Sessions) . . . . . . 84

Preparing for Marriage Inventory . . . . . 84

Temperament Inventory . . . . . . . . . . 85

Fears of Marriage Worksheet . . . . . . . 87

Remarriage Worksheet . . . . . . . . . 87

Marriage License . . . . . . . . . . . 88

Session 9 . . . . . . . . . . . . . . . . . 89

Rehearsal . . . . . . . . . . . . 89

Session 10 (Group--Post-Marital) . . . . . . . 92

Video - After You SaY I Do . . . . . . . . 92

Session 11 (Group--Post-Marital) . . . . . . . 93

The Model . . . . . . . . . . . . . . . . 94

Toronto Perth Avenue Premarital

Education Evaluation . . . . . . . . 95

Statement 1 . . . . . . . . . . . . 95

Statement 2 . . . . . . . . . . . . . . 96

Statement 3 . . . . . . . . . . . . . . 96

Statement 4 . . . . . . . . . . . . . . 96

Statement 5 . . . . . . . . . . . 96

Statement 6 . . . . . . . . . . . . . 96

Statement 7 . . . . . . . . . . . 97

Statement 8 . . . . . . . . . . . 97

Statement 9 . . . . . . . . . . . 97

iii 


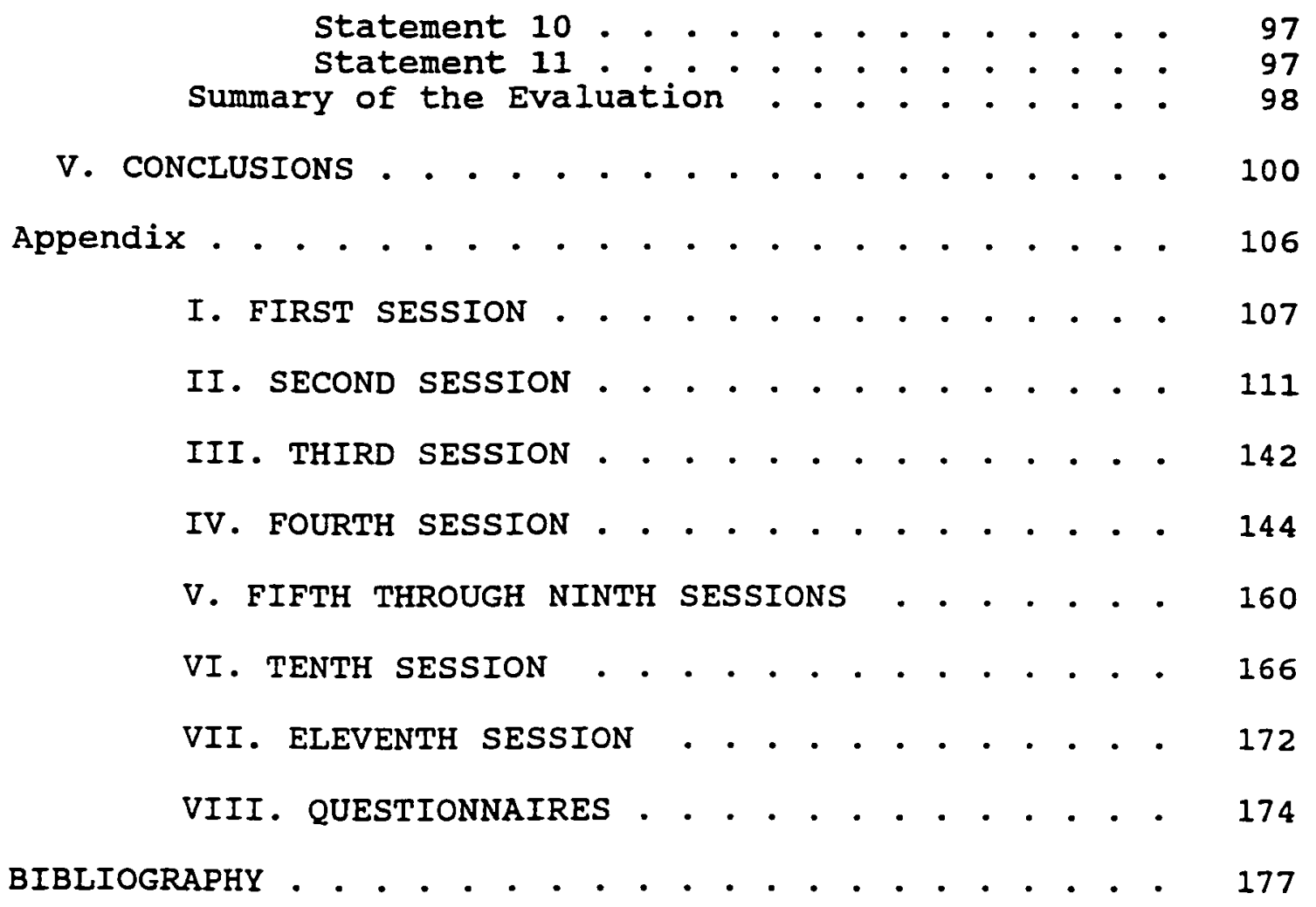


CHAPTER 1

INTRODUCTION

\section{Purpose of the Project}

The purpose of this project was to develop a program of premarital education to prepare couples engaged to be married in the Perth Avenue Seventh-day Adventist (SDA) Church.

\section{Justification for the Project}

Traditionally, the Toronto Perth Avenue SDA Church has not offered any specific program for premarital education. our church is a large metropolitan congregation and the annual weddings average about ten.

From all indications, it seems that the institution of marriage, as was established in the Garden of Eden, will continue to exist, and the service of the ministry, in providing marital education, will continue to be a necessity.

During my past sixteen years of pastoral ministry, I have tried to develop a program that has been very useful in my ministry. I am concerned that many couples have had no preparation for marriage, thus my commitment to premarital education. 
Although I have not decided to specialize in a counseling ministry, I believe that the Toronto Perth Avenue SDA Church should have an educational tool for all couples contemplating marriage.

As engaged couples enter my office for the very first time, I often get the impression that most of them are simply obsessed with the possibility of getting married. They are oblivious to educational tools for couples contemplating marriage. They are unaware of the process, the cost, the preparation, and the execution. Gerald Hill says it accurately when he quotes from the Pastor's Manual for Premarital Counseling:

The majority of couples who come to the minister to plan for the wedding are in a star-studded, romantic obsession. They are planning to undertake the complex and delicate matters of marriage with a deplorable lack of realism and understanding. ${ }^{1}$

This is where I envision the effectiveness of a premarital education program. When a couple approaches a pastor, he can alleviate their fears and at the same time place them on a course that will help them to begin laying the foundation for a solid Christian home. "The job for the pastorcounselor is to encourage such couples to do some realistic thinking." 2

'Gerald Kingsbury Hill, "Premarital Counseling Practices and Attitudes Among Ministers of the Methodist Church," (Ed.D. dissertation, Columbia University, 1969), 4 .

${ }^{2}$ Ibid. 
Then Hill gives the pastor-counselor three areas of focus upon which he can help the couple to begin building a solid foundation:

(1) to realize that they are taking with them into their new home, and to recognize the many new problems and situations that will confront them as they undertake this complete change in their established way of living; (2) to gain information about many facts, principles, ideals, and practical adjustments that are necessary to a successful marriage; and (3) to dedicate themselves to an objective that is far more than their own comfort and security, far greater and bigger than their own lives; the building of a new unit in the present and eternal Kingdom of God, because a christian home is no less this.'

I have observed that over the past ten years a couple preparing for marriage is willing to listen to counsel from anyone in authority. I have also observed that when it comes to premarital education, the couple's first choice has always been their resident minister or a minister closest to that couple. This is a point in their lives when they are most open to receiving pastoral counsel. Eyrich in his premarital counseling manual expressed it this way:

There will be few other times in any given couple's life when they will be as highly motivated to respond to guidance as when they are anticipating marriage. ${ }^{2}$

I have noticed that as we begin to spend these next few months together, the couple becomes energized and charged as

IIbid., 4-5.

${ }^{2}$ Howard A. Eyrich, "A Premarital Counseling Manual" (D.Min. project, Western Conservative Baptist Seminary, 1976), 10 . 
they begin to envision the possibility of a wedding day and a life together. This is one of the best times in the life of a young couple that the pastor can have a significant impact upon their lives.

These facts have sensitized me to prepare myself by pooling together educational information for couples contemplating marriage. Most of the information is not original. However, I feel that when couples are exposed to an educator to whom they can relate and to a relevant program, they can be instructed to develop skills in dealing with married life. In addition, they are also assured that there is someone to whom they can turn when questions and difficult times arise.

Since the pastor is the shepherd of the flock, it would seem natural that he/she would facilitate all the marriages of their couples with a premarital program. This is not the case in most churches. The truth is that the church has done little for premarital education and much for postmarital treatment. Even though we know this is a fact, nothing significant in the area of premarital education has been spearheaded by the church.

No wonder non-church groups are tapping in on the church's gold mine. In the S.D.A. Minister's Manual little or no space is given to premarital education. The S.D.A. Church Manual makes one important statement:

Let those who are contemplating marriage weigh every sentiment and watch every development of 
character in the one with whom they think to unite their life destiny. Let every step toward a marriage alliance be characterized by modesty, simplicity, sincerity, an earnest purpose to please and honour God. Marriage affects the after Iife both in this world and in the world to come. A sincere Christian will make no plans that God cannot approve.'

There is nothing said about a specific premarital educational process.

Ellen $G$. White, one of the SDA Church's most prolific writers, wrote much about marriage but so little on premarital preparation. In one of the few statements where she alludes to some kind of preparation, she expresses it in terms of preparation for "duties" and "burdens." she says,

Before assuming the responsibilities involved in marriage, young men and young women should have such an experience in practical life as will prepare them for its duties and burdens.2

Non-church institutions are expressing concerns about the absence of premarital education in the church and society. One such person is Aaron L. Rutledge (1966), who is the head of the counseling and psychotherapy program of the Merrill-Palmer Institute in Detroit, Michigan. Rutledge feels that the time spent with a couple in premarital counseling "is one of the greatest teachable moments or

'Seventh-day Adventist Church Manual (Washington, DC: General Conference of Seventh-day Adventists, 1990), 148, 149 .

${ }^{2}$ Ellen G. White, Ministry of Healing (Mountain View, CA: Pacific Press Pub. Assn., 1942), 358. 
opportunities for learning."' Rutledge believes that the premarital educator does not need to give the couple a wealth of information. He states that

a minimum of skilled help at this time can affect changes in personality that would take years to accomplish later, and basic ways of handling relationship problems can be developed for a meaningful interaction. ${ }^{2}$

The premarital educational experience provides a unique opportunity to create an atmosphere for the couple's growth and future development.

Premarital counseling is the greatest educational and clinical opportunity in the life of a person because there is still time to affect adult personality changes and at the same time invest in the soon-to-be born children; a chance to influence both the chicken and the egg. ${ }^{3}$

Thus, it has become very evident to me that if marriages are to succeed there has to be much more focus on premarital education. Couples in our church are spending a lot of time in preparation for their wedding day, and in the process they are robbing themselves of an education they so badly need to help them with life after the wedding. Eyrich gives support to this idea when he states that "premarital counseling can be effectively used to clarify to every young

\footnotetext{
'Aaron L. Rutledge, Premarital Counseling (Cambridge, MA: Schenkman, 1966), xiii.

${ }^{2}$ Ibid.

${ }^{3}$ Ibid.
} 
couple that the nature of $\operatorname{men}^{1}$ is not changed by a wedding ceremony."2 Premarital education presents a natural opportunity for a pastor to develop within the minds of a couple coping skills that can minimize conflicts which are created because of the presence of $\sin$.

From my observation, premarital education is effective enough to suggest that it becomes a requirement for marriage. English and Pearson made a very appropriate comment when they wrote,

If the atmosphere of the home, school, church and doctor's offices were geared to the importance of marriage and its attending phenomena, there would be little need for last-minute counseling prior to marriage. But we find ourselves pushing premarital counseling in an effort to compensate for the fact that nearly everyone in the psychosexual growth process is shirking his job.

I am therefore convinced that an adequate premarital educational program can significantly lessen the need for post-marital counseling for any couple.

Stahmann and Heibert have put into focus what the church indirectly is saying to its pastors since the birth of the era of pastoral counseling:

Since the advent of the pastoral counseling movement and the switch in the emphasis of pastoral ministry from simply and explicitly

"I would change "men" to "humanity," since neither the woman or man are changed by the ceremony.

2Eyrich, 6 .

${ }^{3}$ O. Spurgeon English and Gerald H. J. Pearson, Emotional Problems of Living (New York: W. W. Norton, 1955), 400 . 
religious and/or ritualistic, the clergy have been expected, particularly through pastoral counseling courses in seminary, to take responsibility for meeting the personal and counseling needs of parishioners. Publishing handbooks on premarital counseling and book and booklets for couples to read in preparation for their marriage are other ways in which denominations encourage the idea that the pastor is to provide premarital counseling.'

Whether qualified or not, the pastor will be approached for premarital education.

Arthur $M$. Tingue, in a very moving article about the minister's role in marriage preparation and premarital counseling wrote,

I believe that the nature and extent of that counseling will depend upon the accessibility of the minister as a "helping" person. There are certain personality traits that unite with uncompromising theological attitudes to create barriers between the person seeking help and the pastoral counselor. Nevertheless, there are persons who seem to need authoritarian direction and these people often turn to the minister for help. Therefore, the pastor finds himself in counseling relationships regardless of his suitability for counseling or willingness to be a counselor. It is then essential for the minister to prepare himself to deal with marriage counseling and education since these functions are included in his pastoral role. ${ }^{2}$

As a pastor I need to be satisfied that a couple seeking marriage has been adequately instructed from a premarital program that has been tested and proven.

'Robert F. Stahmann and William J. Heibert, Premarital Counseling (Lexington, MA: Lexington Books, D. C. Heath and Company, 1980), 400.

'Arthur M. Tingue, "The Minister's Role in Marriage Preparation and Premarital Counseling," Marriage and Family Living 20 (February 1958): 11. 
In addition to this concern, recent increases in marital difficulties in the Toronto Perth Avenue SDA Church have caused me to become more sensitive to the need for an adequate premarital education program. "There is one divorce for every two new marriages." This high divorce rate does not in any way lessen the desirability of the marriage institution. The church must provide an instructive program for couples preparing for marriage in order to counteract the destructive trends.

When I began pastoring the Toronto Perth Avenue SDA Church, I noticed that almost all of the married couples who were experiencing postmarital difficulties had not received any premarital education. This observation substantiated my decision to become more active and efficient in preparing couples for marriage. I was further convinced that marriage is a major responsibility of the church. As a result, I was challenged to meet the need for a premarital education program.

\section{Limitation of the Project}

This project was limited to a maximum of ten couples of the Toronto Perth Avenue SDA Church. This project dealt strictly with premarital education and not marital counseling.

'Barry K. Estadt, Premarital counseling (Englewood Cliffs, NJ: Prentice-Hal1, 1983), 153. 


\section{Definition of Terms}

Premarital education: I chose this term to identify the pastoral role. However, when quoting, the term premarital counseling is quoted to mean the same.

The program: A shortened term for this Premarital Education Program project. 
CHAPTER 2

\section{BRIEF HISTORY AND CURRENT STATUS OF PREMARITAL EDUCATION IN THE SDA DENOMINATION \\ IN HISTORICAL SEQUENCE}

\section{Dr. Colin Standish}

The history of premarital education in the SDA denomination is very brief and Iimited. The first written document on file at the Family Services Ministries of the General Conference of Seventh-day Adventists is an article written by Dr. Colin D. Standish for Ministry magazine in March 1976. At that time Dr. Standish was the President of Columbia Union college and he entitled the article, "The Pastor and Premarital Counseling."

In his article, Dr. Standish emphasizes the importance of the minister in spending a considerable amount of time as he guides and counsels the couple for marriage. He even made an analogy between marriage and baptism. "The preparation of young people for marriage should be as thoroughly undertaken as the preparation for baptism."l

It was obvious from this article that Dr. Standish was concerned about many of the college students who were

${ }^{1}$ Colin D. Standish, "The Pastor and Premarital Counseling," unpublished manuscript, 2. Cf., idem, "The Pastor and Premarital Counseling," Ministry, March 1976, 18. 
getting married during their college years. Not only did he seem concerned about the marriages, but he showed a similar concern regarding the lack of pre-marital counseling.

Too many of those who marry during their college education are forced into undue strain because of financial responsibilities. Frequently young people are forced away from their Christian education training into worldly schools and colleges and in so doing they are not only restricting their own development, but they are limiting the work that God can do through them in the finishing of His Work.'

In suggesting that ministers should be much more diligent in the preparation of couples for the second most important decision in their lives, Dr. Standish's only suggestion was to introduce the couple to the book the Adventist Home. ${ }^{2}$ It was important to observe that in this article the only references cited were The Adventist Home, Messages to Young People (both by Ellen G. White), and the Bible.

General Conference in Vienna, 1975

In 1975, at the General Conference session in Vienna, Dr. D. W. Holbrook and Mrs. Betty Holbrook were elected to serve the world field in a newly organized department called Home and Family Service. This department had no counterparts on any of the other church levels, thus placing the Holbrooks in virgin territory. The Holbrooks saw the

\footnotetext{
${ }^{1}$ Ibid. , 4 .

${ }^{2}$ Ibid., 6.
} 
need and put on their mantles as they stimulated interest in the family through articles, seminars, workshops, campmeetings, workers' meetings, and other influential forums.

Bill Quigley, then president of the Columbia Union Conference, gave good support to the Holbrooks and their vision and aided them in the establishment of the Metro Washington Family Life Council, an organization in the Washington, D.C., area which spanned three conferences: Allegheny East, Chesapeake, and Potomac.

Ron Flowers, pastor of the Capital Memorial Seventh-day Adventist Church in Washington, D.C., further summarized the Council's history. ${ }^{1}$ The Metro Washington Family Life Council, with a number of pastors and lay family professionals as members, flourished for several years and undertook a number of projects encouraged by the Holbrooks. One of these projects was the preparation of premarital guidance materials for the Seventh-day Adventist Church. A task force was assembled including J. L. Butler, Chaplain and Public Relations Director of Hadley Memorial Hospital in Washington, D.C.; Ron Flowers, pastor of the Capital Memorial Seventh-day Adventist Church in Washington, D.C.; Karen Flowers, homemaker and editorial secretary for Insight

\footnotetext{
'The rest of this section is taken directly from Ron Flowers' unpublished manuscript, Department of Church Ministries, Silver Spring, MD, January 1994, which he sent to me in January of 1994 .
} 
magazine; Jack E. Gibbons, R.N., M.S., Lieutenant-Colonel in the United States Nurse Corps and Chief of Nursing Education and Training Service at the walter Reed Army Medical Center in Washington, D.C.; Nancy Gibbons, homemaker and Periodical Department supervisor at the Review and Herald Publishing Association, Washington, D.C.; Alberta Mazat, Chairperson of the Department of Marriage and Family Counseling at Loma Linda University, Loma Linda, California; Lennox Westney, M.D., Associate Professor of Obstetrics and Gynecology at the College of Medicine, Washington D.C.; and Ouida Westney, Ph.D., Associate Professor of Human Development in the School of Human Ecology at Howard University, Washington, D.C.

Ron Flowers was named as this Marriage Education project task force chair and the group worked for nearly two years in the preparation of a pre-marital education kit. These materials included a three-ring binder with three cassettes and such components as the Marriage Prediction Schedule by Ernest Burgess and resource materials for seven sessions with a couple, six to be done premaritally and one after the wedding. This Seventh-day Adventist approach drew upon the insights of well-known Christian author and counselor H. Norman Wright, who had lectured at the Family Life Workshop at Andrews University in 1977. It also took into consideration the research of Dr. Claude Gulder in 1971, and the work of Edward Bader in Toronto at 
approximately the same period which indicated that, although the premarital period was not a very teachable moment for couples,' through carefully designed approaches which encouraged the couple to discuss with each other a variety of issues, some helpful premarriage preparation could come about.

Accordingly, Marriage Education, as the inventory was first called, puts a heavy emphasis on the use of a special questionnaire called the "Preparing for Marriage Inventory." This ten-part questionnaire covers the topics of selecting a life partner, values and goals, love and feelings, religious beliefs and expectations, roles and responsibilities in marriage, communication and conflict resolution, finances, in-laws, sexuality and family planning, health and habits. It not only gives the individual couple a tremendous amount of insight into each other, but it also provides dialogue material for the couple in the presence of the pastor/counselor during the course of the sessions. In addition, the package provides a large number of exercises and assignments which the couples are to complete between sessions. Additional resources are included--some short essays for reading, recommended selections of readings from

\footnotetext{
'I believe that this is a very teachable time. There are two schools of thought on this matter. Howard Eyrich's Premarital Counseling Manual, 10, paragraph 1, supports this theory.
} 
Spirit of Prophecy books, and other popular christian books on marriage and related issues.

Cassette tapes were included for use by the pastor/ counselor and for loan to the couple. These tapes augmented the other assignments that were given to the couple. Someone estimated that if a couple worked on all the exercises and attended all the sessions as recommended in the package, they would have about 125 hours invested in this premarital guidance. The intent has never been to require couples to give this much time; rather, what has been provided here is some resource material which could be used by pastors and others engaged in helping couples get ready for marriage--materials that can be tailored to suit the individual needs of the couples.

Because of the thoroughness of the curriculum the 1984 Annual Council of the Seventh-day Adventist Church took an action to adopt Marriage Education as a denominationally sponsored plan for premarriage education.

Marriage Education went through three printings for a total of about 1500 copies sold in the early 80s. At the same time as Marriage Education was produced, it was felt that it would be useful to have a companion notebook available for the couples as a workbook. Togetherness, oneness, Joy was developed. It included segments from the Marriage Education notebook with the exercises and assignments included in such a way as to provide a workbook 
for the couples. The latter was translated into Spanish as Education para el Matrimonio, the former as Compañerismo Unión Gozo.

At the beginning of 1980, Ron and Karen Flowers joined the Home and Family Service team at the General Conference of Seventh-day Adventists, and continued to work in the preparation of family life education materials for the church. Both the Holbrooks and the Flowers utilized the Marriage Education materials in workshops and seminars in North America and in other divisions of the Church. Encouraging responses came in about the premarital guidance materials. It was evident, however, that there were some aspects that needed strengthening. Thus, revisions of the material were begun. About 20 percent of the material from Marriage Education was revised based on input from the field, and some additions were made. In 1985 the revised edition was published as preparing for Marriage. The "Preparing for Marriage Inventory" was expanded to include family of origin material and also preparation for remarriage. No further revisions of the material have been done to date.

It should be noted also that the General Conference action of 1984 stimulated wide interest in the use of these materials in other divisions. In 1991 preparation au Mariage, a French translation of Preparing for Marriage, by Roland and Josette Buyck was published in the Franco-Belgian 
Union of the Euro-Africa Division. In 1987 the South Pacific Division produced its own premarital guidance material called Beginnings.

\section{Adventist Engaged Encounter}

While attending a Marriage Encounter session in Harrisburg, Pennsylvania, in 1975, Don and Sue Murray, both assistant professors at Andrews University, decided to use their marriage as a basis for ministry to engaged couples. They started a weekend program called Adventist Engaged Encounter (AEE) in the spring of 1978 at Andrews University. By June 1992, 49 programs had been held with 987 couples attending.

The program is experiential in nature, including a minimum of 6.5 hours of team presentation time along with three hours of individual reflection time and three hours of shared dialogue time for each couple.

Although AEE is designed significantly for engaged couples, recently married couples who are desirous of a growing christ-centered marriage have benefitted significantly from this program.

AEE has five main goals:

1. To encourage a healthy look at one's relationship

2. To provide a structure that promotes spiritual decision-making and commitment

3. To provide a model for communication and conflict resolution 
4. To provide a forum for a couple to look realistically at their own expectations

5. To promote a greater level of acceptance, trust and confidence among couples.'

What makes AEE unique is that group work is confined only to the participating engaged couple. In an article in Insight magazine, Don was quoted as saying:

The encounter is private. There are no structured group dynamics. It is neither premarital counseling nor an informal curriculum. We encourage couples to make a deep spiritual commitment to each other and to the Lord. We do not use gimmicky psychology; the potency is in the Holy Spirit. ${ }^{2}$

AEE is not intended to take the place of premarital education. AEE is intended to augment premarital education by enriching the engaged couple. The Murrays have suggested that the Encounter experience be followed with the Premarital Education program.

During the weekend the couple is taught coping skills, communication skills, commitment, and acceptance. The couple also learns how to commit themselves to growth after the wedding. Conflict skills and other basic skills engaged couples take for granted are given great emphasis.

'Don Murray and Sue Murray, "Witnessing Projects and Their Resources Seminar," unpublished manuscript, Andrews University, June 1992.

${ }^{2}$ Don Murray, "Adventist Engaged Encounter Continues at Andrews," Insight, September 1981, 10. 


\section{Pat Morrison's open-ended ouestionnaire}

Pat Morrison is a campus chaplain at Andrews University. He began his premarital education in 1979 with a basic questionnaire which Dr. Daniel Augsburger used in the early 1970s. Morrison introduced Prepare-Enrich to his program some time later.

Morrison's program is basically for young adult couples, and thus a campus such as Andrews University provides an open field. The couples are expected to attend six 45-minute to one-hour sessions. He chooses supplementary materials from Prepare-Enrich.

The program has six sections, each used as a discussion stimulator. This springboard method, as Morrison calls it, is like a starting point to pick up on their strengths and weaknesses. The sections are:

1. Do you know each other?

2. Do you accept each other?

3. Can you communicate with each other?

4. Are you in love with each other?

5. Are you realistic about your married life?

6. Are you preparing for your marriage?

Under each section are several leading questions. Morrison says there is nothing magical about any of the forty-two questions. He uses this program because he is very familiar with it, he thinks it is as comfortable as a pair of old shoes, and it works. 


\section{General Conference Committee Actions}

In the General Conference Annual Council Meeting in 1978, the members saw the need to develop a worldwide program for premarriage education. The following action is recorded.

To authorize as a pilot program until Annual Council 1979 a program of premarriage education for couples to be married by Seventh-day Adventist pastors. The General Conference Home and Family Service has sponsored the development of this program of premarriage education designed to be used by the pastor officiating at the wedding or by his designate. The program includes cassettes, background reading material, tests, outlines of subject matter and suggested special topics, and is initially available through the Home and Family Service of the General Conference. ${ }^{1}$

\section{Togetherness, Oneness, Joy}

In Ron Flowers' summary of the history of premarital education in the SDA denomination, it was noted that along with Marriage Education, another document was being considered. This document became a companion notebook and served as a couples" workbook. "Togetherness, Oneness, Joy" was developed. Although it included parts from the Marriage Education notebook, they were incorporated in crucial areas so as to provide enrichment for the couples.

This educational kit was designed especially for the engaged couple. It covers a variety of subjects strongly emphasizing the development of a healthy marriage. This

'General Conference of Seventh-day Adventists (Washington, DC), Minutes of Meetings of Annual Council Committee, October, 1978. 
package can be used by a pastor along with a couple in premarital education.

The emphasis is "on the need for you to examine your beliefs and feelings on a wide range of topics and then compare them with that of your partner."1

The involvement entails:

1. Reading of books

2. Cassette tapes

3. Bible study

4. Worksheets

5. Other written assignments

6. A test which the pastor/counselor interprets to help couples discover the kind of persons they are and how they complement each other. ${ }^{2}$

\section{5-84NG Premarriage Education}

The last action taken in 1984 by the North American Division during 1984 Annual Council relates to ministers in the SDA Church and Premarriage Education. The following is the action.

Voted, To adopt this plan for premarriage education: That Seventh-day Adventist ministers provide premarital guidance to couples requesting to be married. Where possible, this premarriage preparation of the couple should consist of several counselling sessions conducted by the minister who is to perform the service or by another qualified individual. For a suggested

\footnotetext{
'Ron Flowers, "Togetherness, Oneness, Joy," Insight, June 1979, 11.

${ }^{2}$ Ibid. , 12 .
} 
method of approach to such premarital guidance, as well as material to share with couples for self-study in instances where personal pastoral guidance is not possible, the General Conference Home and Family Service has prepared Marriage Education, a program which includes study guides, cassettes, background reading material, tests and other pertinent information.'

That is the historical background as it relates to premarital education in the SDA denomination. Several other notable names have emerged when the topic of premarital education surfaces; however, none of them have made any written contributions in that field. These include the following marriage enrichment facilitators: John and Millie Youngberg, family life facilitators; Roger and Peggy Dudley, marriage enrichment facilitators; Peter Swanson, marriage counselor; and James North, marriage counselor.

\section{An Alphabetical Listing of Current Non-SDA} Premarriage Education

$$
\text { Before You Say I Do }
$$

"Before You Say I Do" boasts of being the finest in premarital and early marital counseling. This three-videocassette program with a leader's guide and a couple's workbook is a publication of Evangelical Films, Garland, Texas.

"Before You Say I Do" deals with four general areas of Iife that include:

${ }^{1}$ North American Division of Seventh-day Adventists (Washington, DC), Minutes of Meetings of the North American Division Committee, 1984, 55. 
1. Communications

2. Conflict resolution

3. Money management

4. Sexual intimacy.

Couples are encouraged to first view the videos and then together study the materials. Each person is advised to secure a workbook so that answers can be compared.

The facilitators for each section are:

1. Dr. H. Norman Wright, Communications and Conflict Resolution, who is currently director of Christian Marriage Enrichment (Dr. Wright has authored over forty-five books) .

2. Mr. Larry Burkett, Money Management, founder and president of Christian Financial concepts, a non-profit organization created to minister to christians in the area of finances (Mr. Burkett has authored three books).

3. Dr. Tim and Bev LaHaye, Sexual Intimacy, who have been in the field of counseling for many years. Tim has pastored extensively, and with his wife has authored many books.

The Prepare-Enrich Program

Prepare-Enrich is a pre-marital program which has been distilled from the longer Prepare for Marriage and Enrich for Marriage Enrichment. It has three inventories:

1. Prepare for Marriage

2. Prepare-MC (Marriage with Children)

3. Enrich your marriage. 
All three inventories contain similar content categories and each inventory has 125 items specifically directed to each section. According to the Counselor's Manual, "each inventory is intended to provide a comprehensive picture of relevant issues for premarital or married couples."'

The Counselor's Manual suggests seven invaluable reasons for Prepare-Enrich.

1. It will increase the couple's awareness of areas of weakness.

2. It will create stimulation for couple's discussion.

3. The couple will receive a profile of important relationship issues.

4. The couple will understand the value of open and honored communication.

5. The couple will develop skills which will serve as preventative tools in strengthening their relationship.

6. Prepare-MC will help a couple to discuss issues relating to existing children.

7. Enrich is a premarriage tool.2

For clergy and counselors there are four values:

1. The diagnostic profile provides instant information for the facilitator.

'David H. Olson, David G. Fournier, Joan M. Druckman, Prepare Enrich Counselor's Manual (Minneapolis, MN: Prepare-Enrich, 1982), 1.

${ }^{2}$ Ibid. , 3 . 
2. Because of its clinical value, the facilitator is able to gain greater insights as he analyzes the couple.

3. The counselor is therefore able to give effective advice to relevant issues.

4. Prepare-Enrich is designed to help identify strengths and weaknesses in the relationship. ${ }^{1}$

\section{Sixteen Personality Factors}

The Sixteen Personality Factors Questionnaire, commonly known as $16 \mathrm{PF}$, is a clinical psychological instrument for which professional training is needed in order to administer it and to interpret the data. One must be over sixteen years of age to derive maximum benefit from this questionnaire. 16PF has been around since 1949 with several major revisions. Unless trained to administer this test, pastors should choose another instrument.

\section{Sex Knowledge Inventory}

The Sex knowledge Inventory (SKI) does not require any credentials to administer. A pastor can obtain the Inventory by contacting the Family Life Publications, Inc., Salude, NC.

It would seem wise that the one administering the Inventory becomes very familiar with its contents since sexuality is such a delicate and personal topic. Further, I believe that it is most advisable for the one administering

\footnotetext{
${ }^{1}$ Ibid.
} 
the Inventory to have completed it oneself, and to have carefully processed the results as a learning tool.

Since sexuality is such a sensitive issue, the manual suggests that the counselees circle questions which they would like to explore further with the counselor.

This Inventory is popular but limited to only one area of need. It should be combined with some other marriage education tools. If the topic of sexuality is covered adequately in other inventories, a pastor does not need the SKI.

Taylor-Johnson Temperament Analysis

The Taylor-Johnson Temperament Analysis (T-J.TA) test requires minimal training to administer. The ten-hour training program is available to most pastors by contacting the distributors in Los Angeles, California.

Any pastor will gain excellent insights from the results of this test since the purpose of the exercise is to show the concept of oneself and one's partner. What one thinks of one's partner and then expects from that partner becomes very insightful.

H. Norman wright

H. Norman Wright is a marriage and family life counselor and has authored several books. He has concluded 
that no couple should be married without the benefit of a thorough premarriage educational program. ${ }^{1}$

His book, Premarital Counseling, A Guide for the Counselor, is arguably one of the best in the field. He gives guidelines for the counselor to take the couple through a four- to six-session program. The following is his suggested outline for the sessions:

1. Session one
a. Getting acquainted
b. Marriage defined
c. Family backgrounds
d. Dating background
e. Sexual understanding
f. Preparation for marriage
g. Attitudes toward marriage
h. Spiritual maturity
i. Love defined
$j$. Indications and reasons
$k$. The future of their marriage
1. Homework assignments

2. Session Two
a. Taylor-Johnson test
b. Anticipation of marriage

3. Sessions Three and Four

\footnotetext{
'H. Norman Wright, Premarital Counseling: A Guide for the counselor, rev. ed. (Chicago: Moody Press, 1982), jacket cover.
} 

a. Test results
b. Discussion of homework assignment
c. Sex, the honeymoon, and children
d. In-laws and parents
e. Communication
f. Assign homework

4. Session Five
a. Marital adjustment
b. Friendship
c. Budget
d. Homework assignment
e. Wedding plans
f. Post-marital counseling plans.'

Wright has excellent information, but it may be too concentrated for five sessions. I believe it is more digestible spread out over a longer period or some of the information assigned as compulsory reading.

\section{What Is Being Done by Ten Churches in the Metro-Toronto Area}

Although all this material is available to ministers, as I have dialogued with pastors in Toronto, I have learned that only a few are making use of these rich resources. About four years ago I conducted a mini-workshop on premarital education for SDA pastors in the metro-Toronto area. I was shocked to discover that many of the pastors

\footnotetext{
'Ibid.
} 
were unfamiliar with the model from the General Conference, and they then requested copies of all the documents.

I believe that, generally, pastors are afraid of being labeled as counselors, teachers, evangelists, administrators, etc. This issue becomes most sensitive as it relates to counseling. That is one of the reasons why I consciously selected as my topic, premarital Education. I feel that this title is less intimidating to the average pastor.

As I have communicated with pastors in the metro Toronto area, I have discovered that there is no particular model that is used by the few who are involved in premarital education. The following is a brief study of this situation.

\section{The Questionnaire}

The completed questionnaire that I developed ${ }^{1}$ was administered to ten metro-Toronto SDA pastors. All the information from the questionnaire was tabulated by myself. The results are given in the following summary.

Question 1: About how many weddings do you perform yearly? The average per pastor was four.

Question 2: Do you have a definite marriage preparation program for your congregation? One pastor

'The questionnaire was approved by Dr. Roger Dudley, who is a research specialist. 
responded by saying Yes and No. Four pastors said Yes. Five pastors said No.

Most pastors who responded "Yes" did not have a formal program for their couples. The pastors said that they were expected to administer counseling, so they engaged the couples in a type of free and open-ended discussion.

Question 3: When do you begin your marriage preparation? One pastor responded "Not at all." The five pastors who said that they had no program responded that they began two months before. The four pastors who said "Yes" started six months before.

Question 4: How many interviews do you conduct before the marriage? Those who responded "Yes" averaged seven interviews.

Question 5: How much time do you spend in each of the marriage preparation interviews? The average time among all the pastors was one hour.

Question 6: Do you feel that the church has a definite responsibility in preparing people for marriage? All the respondents checked yes.

Question 7: Do you feel it is necessary as a pastor that you conduct a program of premarital education? All the pastors said that it was necessary to conduct their own premarital program. 
Question 8: What do you consider as the most important topics to be discussed in the interview? The seventeen topics are:

1. Selecting a life partner

2. Values

3. Love

4. Religious beliefs

5. Roles and responsibilities in marriage

6. Communication

7. Conflict resolution

8. Goals

9. Feelings

10. Expectations

11. In-laws

12. Finances

13. Sexuality

14. Family planning

15. Health and habits

16. Family background

17. Remarriage

out of the seventeen topics considered to be discussed in the interviews, six out of the ten pastors said that all of them were absolutely vital. 
Summary of the Questionnaire

From the pastors' perspective, the questions were understandable and answerable. Each pastor completed the entire questionnaire.

The questionnaire gave a clear indication that pastors need an intentional program, not an open-ended discussion that is called a program.

The results were positive since the questionnaire allowed each pastor to evaluate himself and reflect on his program. 


\section{CHAPTER 3}

\section{TOWARD A THEOLOGY OF MARRIAGE \\ AND MARRIAGE PREPARATION}

As I think about the nature of marriage, I believe that the most immediate concern should be an understanding of the authorship of marriage. When the theological foundations of marriage are articulated in its proper perspective, the nature of marriage will be clearly revealed. The true nature of marriage is clearly evident when it is viewed in its theological context.

In this chapter I endeavor to reflect on three theological implications of marriage and marriage preparation:

1. The biblical origins of marriage

2. Scripture and Spirit of Prophecy support

3. The importance of preparation for marriage. But before this is done, let me define a Christian marriage.

\section{A Biblical Definition of Marriage}

The Bible suggests a concise definition when it states, "Therefore a man leaves his father and his mother and cleaves to his wife and they become one flesh" (Gen 2:24). A man and a woman are joined together to become a blessing 
to one another. "One in purpose, one in pursuit of goals, and one harmonious unit is God's desire for us."' "And the Lord God said, It is not good that man should be alone; I will make him a help meet for him" (Gen 2:18). It was God who made the observation that man should not be alone, and He took the initiative in dealing with his aloneness. So God created a mate suitable for the man.

The man must leave parents and cleave to his wife so they can become one flesh. He is no longer responsible to his parents; instead he is responsible to his wife. Oneness is a total commitment of the man and the woman. "As the couple share themselves intellectually, emotionally, and spiritually they become as one. This oneness that God intends is between man and wife and excludes a third person." 2

This initiative by God is so important that it must not be broken by any initiative of men. So God said in His word, "What God hath joined together, let not man put asunder" (Matt 19:6).

In two of his books, Kenneth Morris shares two different definitions of a Christian marriage. He writes,

\footnotetext{
${ }^{1}$ Elliot Osborne, "Development of a Coping Mechanism Seminar for Single Parents Within a Seventh-day Adventist Context" (D.Min. project report, Andrews University, 1989), 22 .

'David H. White, "Development of the Participant's Manual for a Divorce Recovery Seminar" (D.Min. project report, Andrews University, 1986), 11.
} 
Christian marriage is a lifelong union of a man and a woman with the complete sharing of body, mind and spirit as it is set forth in the Bible. It is for the purpose of mutual fellowship, encouragement, and understanding; for the procreation (if it may be) of children and their physical and spiritual nurture, for the safeguarding and benefit of society.'

A little earlier in 1960, Morris gave what I consider to be a more accurate definition. A little longer, but with more depth and breadth, he penned:

We may define a Christian marriage as one involving a Christian man and woman, each dedicated to his understanding of God's purpose for him and to helping his spouse and their children to achieve the measure of the fullness of the stature of christ. In a marriage that is truly Christian, both the husband and the wife will respect the developing personality of the other, aid its enhancement, strengthen it wherever weak, encourage it in its goodness--anticipating old age when both may present themselves to each other, without spot of blemish, even as christ presents the church, His Spouse, to Himself. ${ }^{2}$

Now that we have a biblical and two other definitions of marriage before us, we can begin to appreciate the farreaching implications of this sacred institution and the part of the pastor and the church in its involvement.

In speaking on the subject of marriage, Ellen G. White suggests that it "links the destinies of the two individuals with bonds which naught but the hand of death should sever."3 Ellen White believed that "marriage is a step

'J. Kenneth Morris, Marriage counseling, A Manual for Ministers (Englewood Cliffs, NJ: Prentice-Hall, 1965), 9.

${ }^{2}$ Ibid., 4.

${ }^{3}$ White, Adventist Home (Washington, DC: Review \& Herald Pub. Assn., 1980), 340 . 
taken for life."I It was instituted by God because it was to serve as a blessing for humanity. "That which the eternal Father Himself had pronounced good was the law of highest blessing and development for man." Ellen G. White's views on preparation for marriage are fully developed in a subsequent section.

\section{Brief overview of the Church's Involvement in Premarital Education}

Although there is little written about the church's involvement in premarital education, a search in the literature divided the subject into two major sections: premarital education before World War II and (2) premarital education after World War II.

\section{Premarital Education Before World War II}

The early Christian Church did not involve itself with marriage because it respected the notion of privacy. At that time marriages involved the prospective partners, the parents, and the families involved. Marriages were arranged "with the consent of parents and without the need for priestly or civil authorities." ${ }^{3}$ Parents had complete autonomy over their children's destiny and no one challenged that power. "The power of parents to control the lives of

\footnotetext{
${ }^{1}$ Ibid.

IIbid., 341 .

${ }^{3}$ Stahmann and Hiebert, 6 .
} 
unmarried children was unsurpassed. Since children in essence did not have any standing in terms of legal entity or power under the common law of the day, the control of parents was absolute."1

Since marriage was an affair for the family, it would seem reasonable to assume that the only help a couple would receive was parental model, and admonition and instruction from significant others.

The clergy began to see the issue of permission not only as a parental responsibility, but also ecclesiastical. So several of the church fathers, including Ignatius and Polycarp, "began urging that permission to marry be received not only from parents but also from the bishops." 2 This they hoped would help to ensure spiritual compatibility with the couples. In writing to Polycarp, the martyr and bishop of Smyrna, Ignatius wrote, "It becomes both men and women who marry to form their union with the approval of the bishop, that their marriage may be according to the Lord, and not after their own lust." ${ }^{3}$

The first aspect of the church's involvement in marriage was through a priestly benediction. "By 398 A.D.,

\footnotetext{
'Ibid.

${ }^{2}$ Ibid.

${ }^{3} \mathrm{H}$. T. Christensen, Handbook of Marriage and the Family (Chicago: Rand-McNally, 1964), 443.
} 
the synod of Carthage had already assumed the use of a priestly benediction in the ceremony."l A blessing was being said in a service that was otherwise a civil ceremony. Between the fourth and the tenth centuries the church gained further control by introducing new rules and regulations hinging on its priestly benediction. One such rule stated that "in view of this benediction, virginity should be maintained on the wedding night." 2 Later the church added that "the couple should abstain from any relations for three days and three nights."13 But as time went on, the church revised its policy for monetary gain and "allowed the newlyweds to have coitus on the first night after marriage, as long as they paid a fee to the church."

The period between the fourth and the tenth centuries saw the church making its greatest inroads into the once civil ceremony. During this time, "ecclesiastical control was further reinforced by means of the bridal mass." 5 This mass became the foundation to the pomp and circumstance of succeeding generations and has left its legacy on the church's services even today. "After the tenth century,

\footnotetext{
${ }^{1}$ Stahmann and Hiebert, 6 .

${ }^{2}$ Christensen, 443 .

${ }^{3}$ Ibid.

${ }^{4}$ Ibid.

SIbid.
} 
marriages usually took place in church, under the direction of the clergy."l "By the year 1164, the church had officially established marriage as a sacrament." 2

since the sacramentalization of marriage, the church developed a pattern to instruct couples for this rite as they would for other initiatory sacraments, as it pertains to the life of the church. "Clergy soon began teaching people about the meaning of the sacrament prior to their receiving it." 3 "Thus clergy began seeing couples prior to the wedding."4 The premarital education focused on "the nature and the meaning of the rite itself: the christian nature of marriage, the place of religion in the home, and the rehearsal of the wedding rite."

The Puritans were the first to separate the church from what it perceived as a civil association. This was completed by the Civil-Marriage Act of 1653. "This complete severance of marriage from religion was revoked with the Restoration, when the conditions that prevailed prior to the Commonwealth were restored. 16

'Ibid.

'Stahmann and Hiebert, 7.

${ }^{3}$ Ibid.

${ }^{4}$ Ibid.

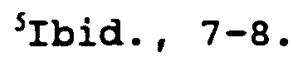

${ }^{6}$ Andrew G. Truxel and Francis E. Merrill, Marriage and the Family in American Culture (New York: prentice-Hall, 1953), 54 . 
For most of the seventeenth century, the New England colonies kept marriage as a civil contract and denied the church any association with marriage. It was the Separatists and Puritans who nailed the final blow in the Massachusetts statute of 1646: "No person whatsoever in this jurisdiction shall joyne any persons together in Marriage, but the Magistrate, or such other as the General Court, or Court of Assistants shall Authorize in such place, where no Magistrate is near."l

Forty-six years later in the statute of 1692 , ministers were allowed to perform weddings. In Rhode Island, however, it took until 1733 until "the settled and ordained ministers and elders of every society and denomination of Christians were permitted to join persons in Marriage. "2 Not much has changed since. "From that time to the present day, it has been the practice in American society to recognize the validity of marriage performed either under the auspices of the church or the civil authorities." ${ }^{3}$ The church therefore found itself giving general instructions on the duties of marriage and family living.

I'Ibid. , 54-55.

${ }^{2}$ Ibid. , 55 .

${ }^{3}$ Ibid. 


\section{Premarital Education After}

World War II

After World War II there was a series of developments in the psychological field which had a dramatic effect on pastoral ministry. "In the 1940 s and the 1950s, a new concern developed in the field of psychology in general and in clinical practice in particular."1 In the 1940 s and 1950s "came a concern with the behavioral problems of children which brought with it a focus on the parent-child relationship." 2 This brought on a new era of concern, "about what was transpiring between people as well as about what was going on inside people." ${ }^{3}$

Some clergy became interested in psychology to enhance their skills in performing ministry. The foremost clergy who developed this new thirst combined psychology and theology, initiating "a movement that we generally recognize by the name of pastoral counseling." 4

In the 1950s and 1960 s the pastor was seen "as being responsible for a marriage's continuing growth." At this period, the pastor was also perceived as the one who examined the couple as to "the emotional readiness of a

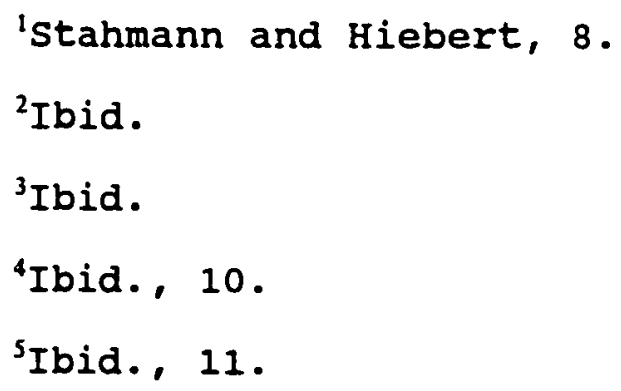


couple for marriage." ${ }^{\prime}$ Thus, a shift took place in seminaries and educational institutions as the new emphasis on premarital education and preparation took rise to meet this new trend. So the pastor's task was being redefined since the clergy was now expected to "examine the emotional and psychological readiness of the couple for marriage."2

From this overview one can better understand why the clergy is still expected to play such a significant role in marriage education. The statistics point out that the clergy is still involved in the majority of premarital education and wedding performances. Shenick's study discloses that "of 4000 couples who applied for married licenses, 2,745 (68 percent) had used the clergy for premarital counseling." ${ }^{3}$

\section{Biblical Principles}

Whenever we touch on the nature of marriage, we automatically find ourselves examining the biblical principles for marriage.

The Bible is clear that marriage is God's plan for the race. When God completed His creation He expressed His satisfaction by declaring that, "it is very good" (Gen

'Ibid.

${ }^{2}$ Ibid.

${ }^{3}$ Ibid., 4 . 
1:31). Part of the goodness was the creation of a woman to be man's companion.

Marriage is not an alternative lifestyle to celibacy or homosexuality. God intended that the man and the woman would enhance each other. Celibacy is a special gift given to those with extraordinary assignments (1 Cor 7:7). Homosexuality is a departure from the natural order of God's design for humans (Rom 1:26-27).

The relationship that God instituted for Adam and Eve was to become a model for humanity. There must always be a leaving; cleaving involves a fusion that results in one flesh. God speaks of the marriage affiliation as a covenant. In the books of Proverbs $(2: 17)$ and Malachi (2:14), God speaks of the marriage relationship as a covenant.

Since marriage is a permanent institution, a covenant, and a lifelong relationship which God designed, the pastor should be held responsible for educating his congregation about matters relating to premarital education. I think even more critically that God will hold the pastor accountable if this duty is neglected. "Therefore when a man takes a wife and a woman takes a husband, they voluntarily commit themselves to each other and enter this covenant relationship before God with all its rights, 
privileges, and responsibilities."' The unique nature of marriage embodies an emotional and a sexual intimacy. "One flesh refers to sexual union. It may refer to more, but its foremost idea is sexual union."2

Because the first couple sinned and fell, their relationship to God and to each other was severely affected (Gen 3:10, 16, 17). Therefore, all subsequent marriages are compromised of the joining of two imperfect individuals. Consequently, every marriage needs pre-nuptial nurture so that it can be cradled and grow in an atmosphere of Christian love. However, the pastor must assure his congregation that God's desire is that both husband and wife find "a good thing" (Prov 18:22).

In conclusion, it was God who originated the institution of marriage (Gen $2: 24$ ). He officiated at the first wedding ceremony in the Garden (Gen 1:28). Because of God's involvement in this process, marriage has been identified as a divine institution (Gen 2:22).

\section{Three Reasons for Marriage}

It would seem to me from the Genesis account that God had three main reasons for instituting marriage. First, when God brought all the animals before Adam and paraded them, it was His way of suggesting to Adam that he was

${ }^{1}$ Eyrich, 2.

${ }^{2}$ Ibid., 3 . 
different. When they passed by in pairs Adam would certainly identify his aloneness. He was without a companion. It was then that God declared, "It is not good for man to be alone. I will make him a helper fit for him" (Gen $2: 18$, RSV). God's first purpose, therefore, was companionship.

Second, sexual intimacy is suggested in Gen 2:24 when it refers to becoming one flesh. A detailed biblical study of sexual intimacy no doubt reveals that sexual intimacy is to be confined to marriage.

Third, God designed marriage for procreation. Through sexual contact they were to be "fruitful and multiply and fill the earth" (Gen 1:28).

\section{The Permanency of Marriage}

In both the old and New Testaments, it is very clear that marriage is to be permanent. The writer of the book of the beginnings wrote, "Therefore shall a man leave his father and his mother and cleave to his wife and they shall become one flesh" (Gen 2:24). Then Matthew, under the inspiration of the Holy spirit, recalled the Genesis passage and added for our edification, "What therefore God has joined together, let no man put asunder" (Matt 19:6)--a clear indication from both Testaments that God intended marriages to be permanent. 
No wonder when the marriage vows are being taken the phrase "till death do us part"l is included. This is surely a reminder to all candidates for marriage that the desired state of marriage is for life; it is permanent.

In addition, Paul, writing to the corinthian church, emphasized that God's ideal is that "the wife should not separate from her husband" (1 Cor 7:10). However, if there has to be any kind of separation, "she should remain single or else be reconciled to her husband" (1 Cor 7:11). Paul continued his counsel to the husband. His counsel is consistent with all biblical counsel in regard to marriage. "The husband should not divorce his wife" (1 Cor 7:11).

The Gospels of Matthew and Mark both record an incident where Jesus was being tested by the Pharisees. "Master, is it lawful to divorce one's wife for any cause?" The Pharisees knew the law; they knew what Moses had said, but they wanted to see if Jesus would contradict Moses so they could accuse Him.

Jesus' answer directed their minds back to the beginning when God made His declaration about a man leaving, cleaving, and becoming one flesh (Gen 2:24). He highlighted God's ideal that any two who were joined by God should never be separated. The Pharisees had not completed their testing and now decided to see if Jesus would contradict Moses,

\footnotetext{
${ }^{\prime}$ Seventh-day Adventist Manual for Ministers (Washington, DC: Review and Herald Publishing Assn., 1977), 143.
} 
their forefather and prophet. So they asked Him this trick question, "Why then did Moses command one to give a certificate of divorce and to put her away?" (Matt 19:7). The Pharisees were hoping that Jesus would try to nullify what Moses did in order to lay some charge on Him. Jesus counteracted their intent by telling them Moses' only reason for allowing a divorce, "For your hardness of heart Moses allowed you to divorce your wives, but from the beginning it was not so" (Matt 19:8). Jesus reminded them of God's ideal for the race. God wanted every marriage to be permanent. Moses, in Deut 24:1, allowed for divorce, but that did not intimate divine sanction of divorce.

\section{Shepherding in the context of Premarital Education}

In scripture, the pastor is compared to a shepherd. The shepherd's sole responsibility is the safety and comfort of all of the sheep. In Isaiah, the prophet records, "He will feed his flock like a shepherd, he will gather the lambs in his arms, he will carry them in his bosom, and gently lead those that are with young" (Isa 40:11, RSV). This figure of God and His people is to become a model for the pastor and his spiritual flock.

When Paul addressed the leaders in Ephesus he said, "Take heed to yourselves and to all the flock, in which the Holy Spirit has made you overseers, to care for the church of God which he obtained with the blood of His own Son" 
(Acts 20:28, RSV). The Bible is clear that the pastor's total responsibility is the caring and nurturing of the sheep, especially the young sheep. Eyrich states, "Does not such shepherding require the pastor to be involved in premarital counseling?"I Premarital education is a time when bonding can occur between the shepherd and two special sheep. "Premarital counseling is one of the most important opportunities for ministry."2

Not only will the shepherd build a bonding relationship during the premarital experience, but "the rapport established now will make it easier to be involved in the excitement of the couple's marriage in years ahead." 3

In the context of the shepherd and the sheep, the pastor provides correction for the couple, "correction of faulty information concerning marriage relationship, the communication process, finances, in-laws, sex and so on."4 The fact is that premarital education may be the only forum for a couple to receive this corrective. As the sheep respond positively to the shepherd's voice, so too will the couple respond to the pastor. "Couples will look forward to

\footnotetext{
${ }^{1}$ Eyrich, 8.

${ }^{2}$ Wright, 45 .

${ }^{3}$ Ibid. , 38-39.

${ }^{4}$ Ibid. , 39.
} 
each session as a unique learning experience and value it highly."I

The United States Air Force Academy boasts of the lowest divorce rate among the population as a whole. "Between the years of 1959, when the first class graduated, and 1970, only 21 of the 4,500 Air Force Academy graduates (.004 percent) were divorced." 2 These statistics take on invaluable significance when one understands that a premarital counseling program is conducted by the chaplaincy for the couples. "Cadets and their fiancees are given intensive preparation for marriage which takes place after graduation from the academy." ${ }^{3}$

As the Good Shepherd relates to the sheep, so the pastor is to relate to his people, his couples. Eyrich summarizes it by saying,

If the Chief shepherd is concerned to guide his sheep in 'paths of righteousness,' then as His undershepherds we dare not desire or do less. Just as He leads towards a goal, i.e., green grass and still waters (in that picturesque language of Psalm 23), so premarital counseling aims at overcoming the potential to wander by establishing goals and objectives and teaching couples how to reach them. Shepherding produces flocking among sheep. The pastor should be interested in seeing newlyweds flock."

\section{${ }^{1}$ Ibid.}

'Ibid., 41. The statistics given are 24 years old but more recent figures are unavailable.

${ }^{3}$ Ibid.

${ }^{4}$ Eyrich, 9. 
The shepherd's duty is to equip all the saints, including those desirous of marriage, so that the body of Christ can be healthy, firm, and strong.

\section{Saving Time in the context of Premarital Education}

A pastor's responsibility is to equip a young couple with coping skills so they can receive the best returns from the limited time they have allotted to them. If after he educates a couple in the wise distribution of the time the Lord gave to them, that couple fails to administer it intelligently, they will have to answer to the Lord. Premarital counseling affords the minister, at least in part, a means of teaching communication skills. "This encounter of seven to twelve hours can lay a foundation for the continual building of a productive life by the couple."1

There is such a high demand on the pastor's time that anything the pastor can do to alleviate this high demand becomes a blessing. I have found that the more preparation couples receive, the less post-marital counseling is required. Wright states, "The findings reinforced the conviction that premarital counseling is a valuable means of offering primary prevention about sommon problems, responsibilities, and satisfactions of marriage. 12

\footnotetext{
'Ibid., 10.

${ }^{2}$ Wright, 38 .
} 
I am convinced that pastors can save invaluable time in their future ministry, but they must be willing to invest those several hours into a premarriage program. Eyrich's conclusion gives support to this when he states, "MY personal experience in marital counseling has convinced me that the average pastor could add untold hours to his future ministry through a proper program of such counseling."l

\section{Understanding Responsibilities in Marriage}

The couple preparing for marriage should be counseled as to their responsibilities in the new union, that this partnership involves total commitment in every aspect of life. They must be guided so as not to have unrealistic expectations of each other in all aspects of marriage.

The picture of Christ and the church must be presented to every couple as a model for marriage. Paul declared first to the women, "Wives, be subject to your husbands, as to the Lord" (Eph 5:22). This is a responsibility which cannot be overlooked or taken lightly. There need not be any intimidation in accepting this responsibility since paul also declared in the previous verse that both husband and wife were "subject to one another out of reverence for Christ" (Eph 5:21).

Then Paul commands the husband to love: "Husbands love your wives, as christ loved the church and gave himself for

\footnotetext{
'Eyrich, 11.
} 
her" (Eph 5:25). What wife will not accept her responsibility in marriage of being subject to a husband who loves her and is willing to die for her? And what husband will not die for a wife who is "subject to him as to the Lord"? These are biblical responsibilities that couples must grasp, concepts they must understand that bring richness and wholeness to their lives as they begin a new life together.

More specifically, because of the cultural baggage we carry, males must understand, in their premarriage preparation, their responsibility as providers. The Bible says in 1 Timothy, "If any man have not care of his own, and especially of those of his house, he hath denied the faith, and is worse than an infidel" ( 1 Tim 5:8).

Likewise with the woman, she must also understand her biblical role. I refer now to one passage as reference. Prov 31 has many responsibilities of a woman. A pastor in premarital education can assign this passage for consideration. I make reference to only two: (1) "She looks after her household" (Prov 31:27) and (2) "She opens her mouth with wisdom and the teaching of kindness is on her tongue" (Prov 31:26).

These are principles that couples need to contextualize in the twenty-first century. In most of our nuclear homes both husband and wife are income earners. Therefore couples need to discuss in premarital preparation such issues as who 
will assume the role of taking care of the laundry, looking after the cleanliness of the home, and budgeting.

In preparing a couple for marriage recently, the question of role responsibility surfaced. Since they were both gainfully employed, she a physician and he an attorney, it was gratifying to hear them say almost simultaneously, "We will do it together."

Should not a couple be made aware of these God-given responsibilities? I think that it is mandatory.

\section{The Importance of Preparation}

In this twentieth century, it seems to me that people prepare themselves for numerous life situations. But the most important of these, a lifelong commitment, requires no mandatory preparation. People take lessons in order to drive an automobile, to become skilled tradespersons, to become competitive athletes, physicians, teachers, or pilots. However, what our society has labeled as the most important institution in life--marriage, family life, child rearing--is given the least, if any, formal preparation. Morris seems like a modern-day prophet because what he wrote thirty-four years ago is absolutely relevant now. "The family is of such great importance to the church and state that courses for men and women in one or more of these fields should be required." are presently offering courses in marriage preparation. 
The premise of this section is that a married couple has a better chance of succeeding if they have been through an adequate, proven, and tested premarital program. Norman Wright summed up the potential outcome of couples who are not exposed to a preparation program when he said, "Too many couples today are committing marital suicide because of lack of preparation." 2

Morris states that "the dire need for adequate preparation for marriage begins early in the school years." 3 I disagree with Morris since most of the literature or child guidance supports the fact that children learn their most important lessons during their formative years--before they begin school. Ellen G. White, a Christian author who wrote on many subjects including child guidance, wrote, "From babyhood the character of the child is to be molded and fashioned in accordance with the divine plan. Virtues are to be instilled into his opened mind. The parents' work must begin with the child in its infancy, that it may

\footnotetext{
${ }^{1}$ Morris, 38 .

${ }^{2}$ Wright, 39 .

${ }^{3}$ Morris, 3 .
} 
receive the right impress of character ere the world shall place its stamp on mind and heart." 1

So the ideal situation is for parents to model the sacredness of marriage in the home. However, the statistics reveal that many of our homes are parented by single individuals--a mother, a father or a grandparent. "The census of 1980 reports 101,487 households in San Bernardino County, California, with their own children present. But one-third of these homes $(30,446)$ have no husband present. "2 clearly the children emerging from these homes should be exposed to a good premarital program.

By the time these young people are ready for marriage, they need to understand marriage in realistic and idealistic terms. They need to understand that we live in an imperfect world and the ones they have chosen are as imperfect as themselves. They need to understand that the masks they see during the dating period come crashing down like the walls of Jericho, and their nakedness appears after marriage. In The Pastor's Manual for Premarital Counseling, the authors ask, "Does the couple realize that there is no such thing as an ideal marriage, because it would take two ideal persons

\footnotetext{
'Ellen G. White, Child Guidance (Washington, DC: Review and Herald Pub. Assn., 1982), 193.

'Osborne, 1 .
} 
to make an ideal union, and such perfect specimens do not exist?"1

Couples need to understand that it takes much more than being in love to nurture a successful marriage. Couples need to be taught coping skills and other preparatory mechanisms which will enhance their abilities to deal with the marital stressors. These skills will place them in the advantageous position of being better prepared to resolve conflicts adequately.

In addition, couples need to be prepared for the inevitable adjustments in marriage. The realities of married life come upon a newlywed much sooner than anticipated. For as soon as the unity candle is blown out, the last bar of the postlude is played, the bridal gown is hung up, and the groom's tuxedo is returned to the rental agency, and they are alone. At that moment reality makes its first visit and if they have not been through a program, this is a natural place for panic to step in. This is why premarriage education is so vitally important. A program can help prepare a couple for that moment.

Every couple must be told that all marriages will have their peaks and valleys. Unless they have attained perfection, there are no exceptions. Again, the Pastor's

'Henry M. Bullock, The Pastor's Manual for Premarital Counseling (Nashville: Abingdon Press, 1958), 23. 
Manual states, "The couple must expect to have some friction and to get on each other's nerves at intervals."I

Premarital education does not train a couple to eliminate all their difficulties, conflicts and problems. Instead, the process prepares the couples to (1) identify an existing problem, (2) admit that there is a problem, and (3) decide together on an amicable way of resolving the challenge. The Pastor's Manual affirms this fact. "The danger to a marriage does not lie so much in the disagreements as in the way in which they are met and handled."2 This is certainly one of the advantages of premarital education for the Toronto Perth SDA Church.

One of the roles of the pastor as a premarital educator is to help disarm the couple of their romantic obsession. The average engaged couple experiences only the romanticism of love and never the hard realities. Such a couple must be helped so that love with all its joys and sorrows, pleasures and pain, richness and poverty, successes and failures can be encountered in some ways during the premarital process. Their plans for marriage, expectations, hopes, and dreams for the future must be placed into proper perspective. Preparation helps a couple to focus, and in some cases refocus, so they can come to grips with the realities of married life.

\footnotetext{
'Ibid., 23.

${ }^{2}$ Ibid., 24 .
} 
The media has falsified the process as it relates to courtship and marriage. In most love stories, whether it is on television or on the printed page, the producers begin with two people who are in love; they are married sometime later; and before the hour, two hours, or the book's final chapter is written, love's cycle of home and children is completed. Again, the Pastor's Manual expresses, "Too often the theme is to have the boy meet the girl, and the blandishments begin with the first few minutes. In a few more minutes they are embracing with many studied poses and passionate gestures. It is then but a step to the fairy tale ending when they get married and 'live happily ever after." "I

Preparation sensitizes couples contemplating marriage to the falseness of the notion that good marriages evolve. It helps them to prepare for a successful marriage. Romance is appropriate in marriage, but it is not sufficient to equip them for the difficult days ahead. Therefore it is my responsibility, as a pastor, to prepare couples to face marital realities. This can be accomplished to some great degree through a premarital program.

The church is as strong as the strength of its families. Morris states that "the family is an integral part of its structure."2 So the church can be strong when

\footnotetext{
${ }^{1}$ Ibid., 25.

${ }^{2}$ Morris, 3 .
} 
based on the marital fortification of its couples. Some feel that unwholesome marriages give birth to apostates. "Many defections from the Church's standards of behavior come out of 'sick' marriages."'

Many denominations have sensed the value of preparation. There is an escalating trend in some of the denominations to mandate a premarital program in their official policy. This action has given rise to a number of ministers seeking adequate training to fulfill the anticipated expectation. In addition, seminaries, colleges, and marriage educators have had to update their curriculum. Following are some excepts from a few denominational statements.

The Methodist Church:

In planning to perform the rite of matrimony the minister is advised to have an unhurried premarital conference with the parties to be married. It is strongly urged that the minister advise and instruct to the best of his ability to the end that the parties to be married become soberly aware that successful marriage is dependent on those spiritual qualities which are best nurtured and kept alive by a constant sense of loyalty to God and to God's organized Church. ${ }^{2}$

The Presbyterian Church in the United States adopted

this policy:

It shall be the responsibility of the minister who is asked to officiate at a marriage to provide adequate time for careful premarital counseling with the parties involved. Attention shall be given to all important aspects of marriage, especially those where problems

\footnotetext{
'Ibid.

I'Ibid., 23.
} 
may arise, whether they be physical, emotional, economic, social, moral or religious. In some instances the minister may deem it wise to refer the couple to a physician or other qualified person for special counseling. . . . This counseling procedure shall be followed not only for those contemplating marriage for the first time, but also for any who may be seeking remarriage. In every instance it shall be the minister's duty to assist the couple in laying firm foundations for the establishment of a christian home.'

The United Lutheran Church in America recommends:

"Each pastor should require regular counseling periods with couples before marriage. In part this may be done with groups, but private and individual conferences should also be required." 2

The Seventh-day Adventist Church adopted this statement in 1984: "That SDA ministers provide premarital guidance to couples requesting to be married." 13

In summary, it appears that preparation for marriage is increasingly recognized as essential. It helps a couple evaluate their present status and equips that couple with tools to continue building a successful relationship. In some instances, fortunately, it can help a couple decide against a commitment for life in a doomed relationship.

I believe that a good premarriage program can keep more couples focused on making their marriages work, eliminating

\footnotetext{
${ }^{1}$ Ibid., 24.

${ }^{2}$ Ibid.

${ }^{3}$ General Conference of Seventh-day Adventists (Washington, DC) , Minutes of 1984 Annual Council of the North American Division, 55.
} 
the option of a divorce. Barber is right when he states that "the big problem is not to keep people who want divorce from getting it, but to keep more people from wanting divorce."'

Marriages require skills which do not come automatically. Skills are taught. If a couple is not taught these skills before marriage, it is very difficult to unlearn bad habits after marriage.

Pastors can begin to give prominence to premarital preparation from the pulpit and other formal forums. They can also introduce this topic in less formal settings like visitation, group discussions, and question-and-answer periods. This is a sure way of informing the old of and introducing the young to the importance of premarital preparation. A pastor can certainly help in the structuring or the restructuring of this project.

\section{Spirit of Prophecy Support for Preparation}

Nowhere in the writings of Ellen $G$. White is there a program suggested for premarital education. In fact, the words premarital counseling, premarital education, marriage education, premarital preparation, and other synonyms are absent from the Index to the Writings of Ellen $G$. White. But E. G. White had much to say about marriage. A book, The Adventist Home, has been devoted to marriage and the home.

\footnotetext{
${ }^{\mathrm{I}}$ Ray E. Barber, Marriage and the Family, 2d ed. (New York: McGraw-Hill Book Co., 1953), 527.
} 
The books Messages to Young People and The Ministry of Healing have complete sections devoted to marriage and marriage preparation.

As one makes a cursory study as it relates to her teaching on marriage, one concludes immediately that what E. G. White says about marriage mandates an intentional premarital program for the church.

Although the terminology of premarital education is not mentioned specifically in the writings of Ellen G. White, I have discovered a number of significant references on the subject. She says, "If those who are contemplating marriage would not have miserable, unhappy reflections after marriage, they must make it a subject of serious, earnest reflection now."1

In warning those who were thinking about marriage, she penned, "Examine carefully to see if your married life would be happy or inharmonious and wretched."2 This is the goal of premarital education: to help couples focus on their choices. Most times a couple would be affirmed by their discovery, or in some cases, rediscovery, or in other cases, the couple would have a change of mind. She made it even clearer when she said to "weigh every sentiment, and watch

\footnotetext{
'White, 43.

Ibid., 45 .
} 
every development of character in the one with whom you think to link your life destiny."1

Although the counsel which Ellen white gave in regard to premarital education was written many decades ago, her counsels are as current as this morning's newspaper articles.

It is true that many of our couples are making wrong choices. Many are not exposed to a premarital program and are sailing into troublesome waters. On this segment she counsels, "Many are sailing in a dangerous harbor. They need a pilot; but they scorn to accept the much needed help, feeling that they are competent to guide their own bark, and not realizing that it is about to strike a hidden rock that may cause them to make shipwreck of faith and happiness." 2 Could not that pilot be the pastor with the process of premarital education?

Ellen $G$. White wrote extensively regarding the model home. Her writings suggest that one can attain this level with God's help and much preparation. When one considers the many dysfunctional homes in our society, where children receive their earliest education, one cries out that the only insurance before marriage is a marital education program. If this is not acquired, history will simply

\footnotetext{
'Ibid.

Ibid., 70-71.
} 
continue to repeat itself in the perpetuation of unhappy homes.

Many couples are misinformed regarding the requirements of a Christian home. Ellen White's ideal is that "a truly Christian home is that of peace and restfulness. Such an example will not be without effect."l In another paragraph she states that "the happiness and prosperity of the married life depend upon the unity of the parties." 2

Premarital education prepares a couple to deal with finances. Ellen $G$. White advises families to become financially independent, "to desire to bear your own weight and not to eat the bread of dependence is right." ${ }^{3}$ She criticizes extravagance, those who are spendthrifts, and families living beyond their means. "You ought to be careful that your expenses do not exceed your income. Bind about your wants." 4

Budgeting, which is a part of almost every premarital program, is given much attention in the writings of Ellen $G$. White. She stressed the importance of living within one's income and avoiding debt like a plague when she wrote, "Many, very many, have not so educated themselves that they can keep their expenditures within the limit of their

\footnotetext{
'Ibid., 450.

${ }^{2}$ Ibid., 84 .

${ }^{3}$ Ibid. , 374 .

${ }^{4}$ Ibid. , 375.
} 
income. They do not learn to adapt themselves to circumstances, and they borrow and borrow again and again and become overwhelmed in debt, and consequently they become discouraged and disheartened."I

Other topics covered in the book The Adventist Home that are taught in premarital education are:

1. Choosing the Life Partner

2. Factors That Make for Success or Failure in Marriage

3. The New Home

4. The Successful Family

5. Father--The House-Band

6. Mother--Queen of the Household

7. Children. ${ }^{2}$

There is definitely much that can be said about Ellen White's counsel in regard to premarital education, although it was not identified as such. Her writings to our youth in the book Messages to Young People are relevant today. "Satan is constantly busy to hurry inexperienced youth into a marriage alliance." 3 Who else can give these youth better guidance than the church with a solid and thorough premarital program. Again she says, "Early marriages are

'Ibid., 374 .

${ }^{2}$ Ibid., 7-10.

${ }^{3}$ Ellen G. White, Messages to Young People (Washington, DC: Review and Herald Pub. Assn., 1958), 455. 
not to be encouraged. A relation so important as marriage and so far-reaching in its results should not be entered upon hastily, without sufficient preparation, and before the mental and physical powers are well developed."l

It is significant to observe that most of the topics found in any good premarital program are included in Ellen G. White's book, Messages to Young People. The topics under Courtship and Marriage are:

1. True Love

2. Wrong Forms of Courtship

3. Engagement With Unbelievers

4. Need of Counsel and Guidance (author's emphasis)

5. Premature Marriage

6. Marriages, Wise and Unwise

7. Marrying and Giving in Marriage

8. Responsibilities of Marriage (emphasis mine)

9. Good Judgment and Self-Control in Marriage. ${ }^{2}$

Ellen G. White's above list is comparable to any modern-day premarriage educator on the subject of marriage (see H. Norman Wright's list). She emphasized preparation in the language of her day, and although her vocabulary does not contain the buzzwords of 1994, the message is the same-seek counsel; no hurried marriages; listen to the voices of reason; prepare for marriage; get instruction; marriage is

\footnotetext{
'Ibid., 438.

${ }^{2}$ Ibid., 14 .
} 
honorable; marriage is permanent so prepare for this lifelong experience. 


\section{CHAPTER 4}

THE MODEL

As soon as a couple suggests to me that they are planning to marry, I make an appointment to see them. Following is the order in which the sessions are conducted.

\section{Session 1}

During the first session, the couple is seen alone to complete:

1. Marriage Information Sheet

2. Guidelines for Wedding Ceremony, Toronto Perth Avenue SDA Church.

\section{Marriage Information Sheet}

The marriage information sheet provides as much data as is necessary for a brief look at any couple's history.

The address and telephone number tell the pastor if the couple is living together or otherwise. This data also informs the premarital educator as to their geographic location. I have counseled with couples where one lived in the city of Toronto and the other as far away as washington, D.C. We had to arrange special weekend sessions when it was 
possible for the three of us to spend a considerable amount of quality time together.

The date of birth and age is quite revealing. The educator can conclude the age difference at a glance. Recently, as I scanned a marriage information form, I observed that the young woman had recently turned eighteen and the young man had celebrated his fortieth birthday. I did not have to ask any questions, the date was staring me in the face. I was convinced that a problem existed and I was right. The young lady's single mother was not in favor of the union and the young woman had waited patiently for her eighteenth birthday to make her own decision.

There are many illegal immigrants in our large cities. People visit large thriving cities and stay without acquiring proper documents. Sometimes they may marry a citizen of that country to secure their desired status. Many times these marriages are for convenience. When a pastor realizes that one partner is illegal, he should feel uninhibited to inquire as to the motivation behind the marriage.

In an extremely cosmopolitan city like Toronto, two people may come together representing two totally different cultures. Recently I had premarital education with a couple where the young woman is of West Indian background and the young man's nationality is Nigerian. We covenanted before 
the premarital education began that they must see another counselor who specializes in cultural diversity.

Church members are oftentimes unaware of the church's policy as it relates to weddings. Occasionally a member would present him/herself along with a non-SDA requesting marriage. The marriage information sheet makes the educator aware of this problem of church affiliation.

Parents' birthplace is informative because it gives some focus as to the scope of one's geographic boundaries. Parents may originate from different countries. The child may be born in still another part of the world. Presently the family may live in a totally different country. Susan's parents lived in Jamaica. Several years after marriage they immigrated to England where Susan was born. At age four her family migrated to Canada where Susan eventually met and fell in love with A.J. who is of Lithuanian descent. We shared extensively during our sessions. They were also recommended to see another marriage counselor.

The present status of the couple may reveal important information for the pastor. Many divorced persons are unaware of the biblical requirements for remarriage. When a pastor observes that one party is divorced, he may simply ask for a copy of the final divorce papers to see the grounds under which the divorce was granted and to ensure that the divorce has actually taken place and is finalized. 
He can make intelligent decisions after making his observations.

A couple may have a proposed date for their wedding. But a pastor may already have made a commitment for that day. Neither party may be flexible, so before any further discussion, the couple may choose to find another pastor to perform the ceremony.

In summary, the marriage information sheet can act as an important data base. By keenly observing the sheet, the educator can ask pertinent questions which may save much time in the overall process.

\section{Guidelines for Wedding Ceremony}

The Guidelines for the Wedding Ceremony state very clearly that "the Perth Avenue SDA Church is dedicated exclusively to the service of God." holds dearly to the sacredness of marriage, the congregation expects that the couple's plans will be in harmony with "the guidelines set out in this form." 2

The document sets forth three sections:

1. Reverence

This is a reminder to the informed and information to the uninformed. The Perth Avenue SDA Church cautions against profanity on its property. In addition, smoking and

"Guidelines for Wedding Ceremony," unpublished Ms, Perth Avenue SDA Board, rev. ed., May 1992.

${ }^{2}$ Ibid. 
the use of any alcoholic beverage are forbidden on the church's premises.

The desecration of the church is tabooed whether it is by the throwing of rice or confetti, the wearing of inappropriate attire, or the use of inappropriate music.

In addition, the use of any kind of paraphernalia, e.g., tape, tacks, etc., "on woodwork or furniture is prohibited."'

2. Clean-Up

It is the responsibility of the couple to make the necessary arrangements for the premises to be cleaned. This may take the form of a clean-up crew or a contract with the local church janitor.

3. Financial Arrangements.

The Perth Avenue SDA Church has adopted a policy in regard to a monetary charge for the use of the church's facilities for wedding ceremonies and receptions. When nonmembers request the use of the facilities, the charge is greater than that for a member requesting use, since the member normally supports the church with tithes and offerings (see appendix).

'Ibid. 
Session 2

The second interview takes place in a three-hour group session. All the couples complete the same tasks. They must complete:

\section{Preparing for Marriage Inventory}

This inventory will be used as a basis for the individual sessions in the future. Without consulting his or her partner, each person must be as thorough as possible while completing the inventory. Ron Flowers, in his article, suggests that the inventory will

lead a couple into an evaluation of themselves, each other, and their relationship. Although inventories differ in their style and comprehensiveness, the basic format is a questionnaire that may use a variety of methods of response (short written answers, multiple choice, agree-disagree rating) to a series of questions and/or statements. Topics generally include selfconcept, love, communication, religious expectations, sex, finances, in-laws, anger and conflicting family planning, values and goals. The inventory may be used unaided or in sessions with a pastor/counselor. Such an instrument frequently opens the way for important self-disclosure on the part of the prospective bride and groom and leads to a deepening (or in some cases a terminating) of their relationship. ${ }^{1}$

The inventory is to be completed in its entirety and

discussed in later sessions.

2. Fears of Marriage Worksheet

This worksheet requires the couple to list any fears

that are being experienced as they prepare for marriage.

They are encouraged to state these fears even though they

'Ron Flowers, "Good Marriages Don't Just Happen," Ministry, March 1982, 55. 
may seem trivial or unwarranted. There are some general fears that are shared by most couples, e.g., the fear of death, the fear of illness, the fear of confusion on the day of the wedding. These are fears that almost everyone experiences. They are asked to list as many as they are experiencing. These are shared in the individual sessions. 3. Remarriage Worksheet

This simple worksheet is for anyone who has been married previously. The four sections allow divorcees or those widowed to express themselves and at the same time it is information for the partner. The four statements are:

Statement 1: Things I appreciated in my previous marriage. This is important for the new spouse to understand. We must try and appreciate our spouse's likes and dislikes. Usually, there have been at least a few things favorable in the previous relationship. If there were, they need to be noted.

statement 2: The things not appreciated in the previous marriage. The statement is dealt with in a similar fashion as with statement one.

Statement 3 relates to the failure of the marriage. I think it is expedient to hear from the divorced or widowed as to the reasons, whether objective or subjective, for the Eailure. 
The final statement for the divorced or widowed to answer in the presence of the future partner has to do with avoiding those pitfalls in the next marriage.

Couples have always found this section quite helpful because it helps the divorced or widowed to come to grips not only with the weaknesses of the previous marriage, but it brings to bear on the strengths as an asset for the new relationship. Sharing this information also helps to lay the pain of the former relationship to rest. If there is serious unresolved grief or pain, I refer this couple to another professional in the needed area.

4. Temperament Inventory

The Temperament Inventory is administered for several reasons. First, it informs the couple of the four basic temperaments in life--phlegmatic, sanguine, choleric, and melancholy. It also suggests to the individual what appears to be his or her basic temperament or a combination of temperaments. It is a self-analysis with a Christian viewpoint. It is one of several instruments to assist in understanding human behavior.

The couples complete these inventories and worksheets which are placed in a folder identified for each couple. This information is used in later sessions. 


\section{Session 3}

Before You Say I Do

Couples are asked to arrive on time for the third session, which is a three-hour session. In order to keep the attention, a series of four videos entitled "Before You Say I Do" is shown. Discussion is interspersed among the videos. Couples have repeatedly expressed their appreciation for these videos.

The following areas relating to professional services are covered after discussing the videos:

1. Photographer

2. Videographer

3. Jeweler (for wedding bands or watches)

4. Caterer

5. Florist

6. Coordinator

7. Organist

8. Clothing Designer

9. Transportation Consultant.

Each of these professional service representatives is allowed a few minutes to make a presentation and is permitted to set up a booth where the couple may visit with them. Then business cards are exchanged and possibilities are discussed at their leisure. Couples just beginning their preparation find this very educational. Those who 
are well into planning use the time to compare prices and services. The booth visits end this session.

\section{Session 4 (Individual Couples)}

Reading Assignments

In session 4, a bibliography for those engaged to be married is discussed with each couple. I emphasize that this is required reading and a one-page report must be turned in on each required book. Eight of the seventeen books are assigned reading because they cover the basic areas of love, communication, sex, finances, role distinction, and adjusting. They are:

1. The Act of Marriage. Tim and Beverly LaHaye. Grand Rapids, MI: Zondervan, 1976. 294 pp.

This book is what I call the couples' bible. The LaHayes discuss very candidly all aspects of marriage. Included in this document is an entire section about sexual concerns, along with information in answer to common questions about sexuality.

2. If Only He Knew, Gary Smalley, Grand Rapids, MI: Zondervan, 1982. $162 \mathrm{pp}$.

This is a valuable guide for each male as he continues to understand, know, and love his mate. From his research Smalley gives suggestions for each groom to become a good husband.

3. For Better or for Best, Gary Smalley, Grand Rapids, MI: Zondervan, 1979. $169 \mathrm{pp}$. 
This is the companion guide to If only He knew. It sensitizes brides to male behavioral patterns and helps her see into the mind of the groom.

4. Communication--Key to Your Marriage, H. Norman Wright, Glendale, CA: G/L Publications, 1974. 193 pp. Wright is probably the best Christian author who addresses the subject of communication. This book enlightens the reader in new ways of verbal and non-verbal communication.

5. Intended for Pleasure, Ed and Gaye Wheat, Old Tappan, NJ: Fleming H. Revell, 1977. 213 pp.

This is a reference book on human sexuality with visual aids, written by a Christian family physician and his spouse. This is sexuality from a medical standpoint. Although detailed, the reading is extremely easy.

6. The Birth Order Book, Kevin Leman, Old Tappan, NJ: Fleming H. Revell, 1985. 190 pp.

This book gives some suggestions as to how birth order influences the way we are. It deals with the four aspects of birth: first born, middle children, last born, and an only child and is an excellent christian psychological document.

7. The First Years of Forever, Ed Wheat and Gloria Okes Perkins, Grand Rapids, MI: Zondervan, 1988. 191 pp.

The first years of marriage are crucial to a couple's marital survival. These years can make or break a potential 
lifelong relationship. This book sensitizes any couple to the pitfalls of the first years of life together.

8. Answers to Your Family's Financial Questions, Larry Burkett, Pamona, CA: Focus on the Family Publications, 1987. $215 \mathrm{pp}$.

Burkett has made this book very attractive with a question-and-answer format. He covers a wide range of topics as he shares pertinent and valuable information.

I recommend these books listed; however, I make it clear that my recommendation does not endorse every statement, concept, and view made by the authors.

\section{Guidelines for Planning Your Wedding}

The Guidelines for Planning Your Wedding' help equip the couple with additional resources for the planning of the wedding service. I lead the couple through the resource materials, reminding them that the vows and the wedding prayers are optional.

Section 1 furnishes the couple with a variety of written prayers, termed traditional and non-traditional. In addition, there are a number of vows from which the couple may make a selection. These include:

1. Traditional vows

2. A variation of traditional vows

3. Non-traditional vows

'The origin of this document is unknown to the author. 
4. Vows to be said to each other.

It includes wedding information specifically for the minister which has been extremely significant for me. This is my guide on the wedding day.

1. The wedding coordinator's name and phone number is available to the pastor.

2. The audience stands during bridal processional: Many couples take it for granted that the audience stands only at the bride's entrance. However, many modern-day brides and grooms are requesting that the audience stand during the whole bridal procession. Prior discussion of this topic can save undue embarrassment.

3. Minister's clothes and wedding colors: In some churches the ministerial robe is worn when conducting a wedding ceremony. This is never forced upon the couple. They may prefer a suit. At times they may rent a tuxedo for the minister. These matters must be discussed in advance. In addition, I have seen minister's suits and ties clash with the wedding colors. This information form can prevent that mishap.

5. The "Who gives" response: The traditional question asked by the pastor is "Who gives this woman to be married to this man?" In the past decade, the responses have varied drastically from, "I do" to "Her mother and I do," "We, her parents, do," and "We all do." This response needs to be decided so that the minister is not left in shock. 
6. Vows: If the couple has chosen a vow, the minister needs to know. In addition, it is imperative to know how these vows will be exchanged and by whom.

7. Unity candle ceremony: The unity candle ceremony brings much symbolism with it. The candlestick holds three candles. Before the wedding party enters, the two outer candles are lit, representing the lives of the two individuals as they enter the place of the ceremony. At the end of the service the couple takes those two candles and together they light the middle candle, representing the joining of the two lives. The two outer candles can either be left lit as a symbol of the two individuals or they are blown out to focus on the joining of the two lives. When couples understand the significance of the unity candle, they usually make it a part of their service.

8. Introduction: Many couples wish that their parents also be introduced to the entire audience during the ceremony. Plans can be made to have this done at the time requested by the couple.

9. Prayer: The couple chooses a prayer and informs the pastor.

10. Announcement of reception: There may be changes in the original plans. At times there are late guests or other unexpected problems. If it pertains to the time or location of the reception, an announcement is appropriate. 
Promptness in attending the reception can be important to emphasize.

The Bride's Calendar

Many couples begin to panic very early because they feel that some items are overlooked and others forgotten. The bride's calendar takes that stress away since everything a bride needs to remember is in this document. She is given detailed information in the following sequence:

1. Six months before

2. Three months before

3. One month before

4. Two weeks before

5. One week before.

\section{The Groom's Checklist}

The groom is given a checklist detailing information similarly:

1. Six months before

2. Three months before

3. One month before

4. Two weeks before

5. One week before.

In addition, there is a guide for the couple explaining which family traditionally pays for specific services. I have noticed, however, that young couples are increasingly responsible for their own expenses. 
The final page is a checklist of other general items, e.g., the cake, the baker, the hall, etc.

\section{Sessions 5-8 (Individual Sessions) \\ Preparing for Marriage Inventory}

The Preparing for Marriage Inventory was prepared by the Home and Family service of the General Conference of Seventh-day Adventists, as previously stated in chapter 2 . since the inventory was completed during the second session, the pastor is now able to guide the couple as they exchange answers on all of the statements. During these sessions the pastor must pick up on key words or phrases which can facilitate meaningful dialogue between the couple.

For example, in one session with a couple we were discussing sexuality and family planning. The question for discussion was, "Do you plan to have children?" The young man circled Yes and the young woman circled Yes, No and Uncertain. That caught my attention. As we dialogued it became evident that the young woman wanted to have children but feared that the pain would be too excruciating. As we further developed the concept of bearing pain, she revealed to us that very early in her childhood she developed a phobia towards pain. She had not overcome this anxiety. I recommended a good family counselor to them and a few weeks later she was healed of her fears.

The main function in these sessions is to compare answers and to identify concerns. Another good example is 
found in the statement, "Disagreements usually are settled by one partner or the other giving in." When one says agree and the other responds by checking disagree, the pastor should be alerted to discuss this conflict. All statements must be read, answers compared, and dialogue entertained whenever and wherever necessary. When this inventory is concluded, the pastor should lead the couple into an open and frank dialogue on any aspects of the inventory which may still cause some concern. At the conclusion of this exercise the Preparing for Marriage Inventory is completed.

\section{Temperament Inventory}

Temperament Inventory is published by Andrews University Press and authored by two former professors at Andrews University, Drs. Robert Cruise and w. Peter Blitchington. This is not a clinical evaluation; it is an inventory of temperaments. The participant must answer "Yes" or "No" to eighty short statements. When completed, a prepared score card is placed over the answers enabling percentiles to be assigned to each temperament. The highest percentile identifies the temperament of the participant. "This test, the Temperament Inventory, is based on the four temperament theory. It has been scientifically researched, using a sample of over 4,500 people."1

${ }^{1}$ Peter Blitchington and Robert J. Cruise. Understanding Your Temperament (Berrien Springs, MI: Andrews University Press, 1979), 1. 
The four temperaments are: Sanguine, Phlegmatic, Melancholic, and Choleric. The Temperament Inventory "is one of the few scientifically validated four temperament tests in existence." "The couples are informed that there are no good or bad, wrong or right temperaments, but the temperaments are different. The purpose of this inventory is to educate the couple in understanding their temperaments and how they can impact their relationship. In short, the four-temperament approach is relevant to every part of their life. ${ }^{2}$

The couple is then led through the interpretive document. The strengths and weaknesses of each temperament are explored in four sections:

1. Emotional Characteristics

2. Relationship to others

3. Work and other Activities

4. Greatest Needs.

The Temperament Inventory is not the only way to understand human behavior, but it is a simple approach. No matter what their particular needs may be, it is anticipated that the couple will find this material practical and helpful. ${ }^{3}$

\footnotetext{
'Ibid.

${ }^{2}$ Ibid.

${ }^{3}$ Ibid.
} 
Fears of Marriage Worksheet

The Fear of Marriage Worksheet is exchanged between the two parties. The purpose of this exchange is to help the parties to see, sometimes for the first time, what is going on in their minds. I then ask one of them to begin to read the list while the other takes the time to express carefully and clearly that fear of marriage. After articulating the fear, I then ask the respondent to tell us what the other can do to alleviate or minimize this fear.

I have found this exercise to be extremely rewarding for both parties. I have heard responses like: "I didn't know you felt this way," "Why didn't you tell me this before?" "That's nothing for you to worry about." The outcome is always rewarding as information is shared from deep inside. Couples are absolutely honest in stating their innermost fears and the responses are kind, caring, and affirming.

\section{Remarriage Worksheet}

The couple who falls into the remarriage category shares meaning fully as we explore the following together:

1. The things appreciated in the previous marriage

2. The things not appreciated in the previous marriage

3. Things that caused the marriage to fail

4. What is being done to avoid these failures from recurring. 
There are two main benefits from this exercise. First, the divorcee or widowed is being affirmed because there were some positive aspects about the first marriage. The other party is being instructed. Second, the couple learns from the mistakes of the previous marriage. This worksheet can be meaningful and insightful as the information gleaned, positive and negative, is assimilated.

The inventories and worksheets should take four onehour sessions. If more time for sharing is needed, the pastor should feel free to accommodate this need or, if a professional is needed, make a referral.

In my premarital education, I have worked very closely with a Christian marriage counselor who specializes in individual, marriage, and family counseling. I have found his services to be extremely insightful to those referred. The couples have always expressed deep appreciation for this godly man.

Marriage License

At this point, I discuss with the couple the procedure for obtaining the marriage license. An information and application form is explored in detail. I suggest that the license be obtained a maximum of two weeks in advance. I recommend that the couple make that day special.

When the license is obtained, the couple usually gives it to me on the Sabbath following the last session or at the time of the rehearsal. There are two reasons for this: 
1. The license is safely stored in the church's files. on the day of the wedding there is no embarrassment. It is not lost; it is not forgotten.

2. The province of Ontario, Canada, requires the one performing the wedding to give complete information to the questions asked. Time must be allotted to complete the license accurately. When the license is properly documented, the couple checks the data, and along with witnesses, signs it and much precious time is saved.

\section{Session 9}

Rehearsa 1

At some point during the fifth through the eighth sessions, I give the couple photocopies of several wedding services. This gives them some flexibility in choosing an order of service and planning for the reception. When the couple appears for the rehearsal, they present a copy of the program to me. The reason for giving the copies early is twofold: first, to encourage the couple to pray about the ceremony, the reception, and the participants, and, second, to allow the pastor a chance to examine the document before it is printed. It is the pastor's responsibility to help make the service as joyous and professional as possible. The rehearsal is a time to allow the couple to be seen working together publicly. The couple verbalizes their intent and the coordinator implements the plan. When all of the participants are present, prayer is offered and the 
pastor explains briefly and clearly why these things are being done. In harmony with our previous discussion, I then instruct the couple to clearly inform the participants as to the order of the service, reminding each person of the duty to be performed. The pastor must insist that the entire bridal party be present and on time. Those who arrive late cause much anxiety and prohibit a smooth rehearsal. The complete party includes:

1. Bride and groom

2. Bridesmaids and groomsmen, including the Maid of Honor and the Best Man

3. Ushers (if different from groomsmen)

4. The one escorting the bride down the aisle

5. Flowergirls, junior bridesmaids

6. Ringbearers, Bible boy, junior groomsmen

7. Wedding coordinator

8. Musicians

9. Minister (s)

10. Unity candle participants.

After instructions are given to the participants, the pastor reminds them of their duty to attend to the bride and groom, then the coordinator executes his or her instructions. This is the couple's wedding and it is an honor to have been asked to participate. Too often the participants and parents try to force their own suggestions 
and values on the couple. The couple needs to have their suggestions tried and evaluated.

I shall never forget how terribly one family behaved when the couple decided to stick to their original suggestion in lieu of the one proposed by the family of the bride. The couple instructed the attendants to enter the sanctuary in a certain manner. The mother of the bride and her associates suggested something different. When the couple insisted on doing it their way, the mother rallied her troops and left the rehearsal in disgust. I spent a long time encouraging her to return and reminded her of her supportive role as a parent. The wedding was for the couple, not to boost her ego.

When instructions are clearly understood and everyone is positioned, the coordinator takes over until the couple is satisfied. At the end, we reassemble to confer with the couple as to their level of comfort. Do they need to add anything? Do they need to change anything? Are they completely satisfied? If answers are given in the affirmative, we then remind the participants to be punctual on the wedding day, to attend to and not command the couple and wear a bright smile. If they are not satisfied, we regroup and try other methods until the souple is satisfied. Prayer is offered in closing.

The last two sessions which follow are optional since attendance is subject to convenience. 
Session 10 (Group--Post-marital)

"After You Say 'I Do'" Video

A series of videos entitled "After You Say 'I Do'" is the companion to the "Before You Say I Do" series which was referred to in chapter 2 .

six months after the wedding, the newlyweds come together to view and discuss the topics presented. As with "Before You Say I Do," the presenters are identical. The contents are now focused on the married couple.

Section 1--H. Norman wright
A. Communication: Key to Your Marriage
B. Learning to Listen and Understand Verbal and

Nonverbal Communication
c. Speaking Your Mate's Language
D. Resolving Marital Conflict

Section 2--Larry Burkett

A. Setting Up a Family Budget

B. The Money Barometer: Economic Danger Signs in

Marriage

c. Establishing Long Range Financial Goals and Planning For the Unforeseen

D. Questions \& Answers on Finances

Section 3 - Dr. Tim \& Bev LaHaye

A. Questions \& Answers on Sexual Intimacy

B. Sexual Adjustment in Marriage 
c. Questions \& Answers on Sexual Adjustment in Marriage ${ }^{1}$

After each section, a period of time is allotted for discussion and questions. Much is achieved here since the couples are bringing fresh experiences to the discussion. At the end of the last session we contract for a date six months later.

Session 11 (Group--Post-marital)

Six months later the couples assemble for a rap session and an open forum. At this session, my wife and $I$ and three couples who are involved in family life as paraprofessionals are present. These persons assist me in the program. There is no set agenda, but discussion is always lively and the time spent together electrifying.

At some point in the session, the group is separated by gender for sharing. During this time the experienced facilitators answer questions and lead out in areas of felt needs.

At the end, a season of prayer is conducted for all the couples present and goodbyes are said. It must be mentioned that the newlyweds always request another session or two. But in place of the requested sessions, we recommend a very active club for couples at the Perth Avenue SDA Church. Many of those couples presently hold a membership there.

\footnotetext{
'Robert J. Good and Robert Ziegfeld, After You Say "I Do" (Garland, TX: Haughton Publishing Co., 1986).
} 
Following is a summary of the premarital sessions.

The Model

1. First Session

A. Marriage Information Questionnaire (Individual

Couple)

B. Guidelines for Wedding Ceremony/Reception,

Perth Avenue SDA Church

2. Second Session

A. Preparing for Marriage Inventory (Group

Session)

B. Fears for Marriage Worksheet

c. Worksheet--Remarriage

D. Temperament Inventory

3. Third Session

A. Professional Services (Group Session)

B. "Before You Say 'I Do'"

4. Fourth Session

A. Reading Assignment (Individual Couple)

B. Planning Your Wedding Guidelines

5. Fifth through Eighth Sessions

A. Discussing Inventories (Individual Couple)

B. Worksheets

C. Marriage License Form

6. Ninth Session

A. Rehearsal 
7. Tenth \& Eleventh--Postmarital (optional)

A. "After You Say 'I Do'" (Group Sessions)

B. Rap Session, Question-and-Answer Period

Toronto Perth Avenue Premarital

Education Evaluation

The completed evaluation that I developed ${ }^{1}$ was administered to ten couples who have been through the program. All the information from the evaluations was tabulated by myself.

The individuals were asked to reflect on the Premarital Education program and to circle the number that best indicates their response. The possible responses are as follows: 1--Extremely helpful; 2--Moderately helpful; 3--Neither helpful or unhelpful;;4--Moderately unhelpful; 5--Extremely unhelpful.

\section{Statement 1}

Statement 1 says: "The presentations by wedding resource professionals was . . ." of the 20 respondents, 14 said, "Extremely helpful" (70\%); 3 said "Moderately helpful" (15\%); 1 said "Neither helpful nor unhelpful" (5\%); and 2 gave no answer $(10 \%) .{ }^{2}$

'The evaluation was approved by Dr. Roger Dudley, who is a research specialist.

${ }^{2 A}$ "No" response could mean that the persons were absent when the presentations were made. 


\section{Statement 2}

Statement 2 says: "The video, "Before You Say 'I Do'" was . . " of the respondents, 13 said, "Extremely helpful" (65\%); 6 said "Moderately helpful" (30\%); and 1 gave no answer (5\%).

\section{statement 3}

statement 3 says: "The information gained from the Prepare for Marriage Inventory" was..." of the 20 respondents, 18 said "Extremely helpful" (90\%); and 2 said "Moderately helpful" (10\%).

\section{Statement 4}

Statement 4 says: "The Fears of Marriage Worksheet was - ." Of the 20 respondents, 11 said "Extremely helpful" (55\%); 6 said "Moderately helpful" (30\%); 1 said "Moderately unhelpful" (5\%); and 2 gave no answer $(10 \%) .1$

\section{Statement 5}

Statement 5 says: "The reading material was . . ." of the 20 respondents, 18 said "Extremely helpful" (90\%); 1 said "Moderately helpful" (5o); and 1 said "Extremely unhelpful" (5\%).

Statement 6

Statement 6 says: "The Temperament Inventory was

'No answer means that they had no fears. 
-. ." Of the 20 respondents, 15 said "Extremely helpful" (75\%); 3 said "Moderately helpful" (15\%); and 2 gave no answer (10\%).

\section{Statement 7}

Statement 7 says: "Guidelines for Wedding Ceremonies was..." of the 20 respondents, 14 said "Extremely helpful" (70\%); and 6 said "Moderately helpful" (30\%).

\section{Statement 8}

Statement 8 says: "The Wedding Prayers were..." of the 20 respondents, 13 said "Extremely helpful" (65\%); 5 said "Moderately helpful" (25\%); and 2 gave no answer (10\%).

\section{Statement 9}

Statement 9 said: "The Wedding Vows were..." of the 20 respondents, 16 said "Extremely helpful" (80\%); 3 said "Moderately helpful" (15\%); and 1 said "Neither helpful or unhelpful" $(5 \%)$.

\section{Statement 10}

Statement 10 says: "The Bride's Calendar was. . ." of the 20 respondents, 12 said "Extremely helpful" (60\%); 5 said "Moderately helpful" (25\%); 1 said "Neither helpful nor unhelpful" (5\%); and 2 gave no answer (10\%).

\section{Statement 11}

Statement 11 says: "The Groom's Checklist was . . ." of the 20 respondents, 11 said "Extremely helpful" (55\%); 6 
said "Moderately helpful" (30\%); 1 said "Neither helpful or unhelpful" (5\%); and 2 gave no answer (10\%).

After the eleven statements, a final question was asked: "What suggestions can you share for improving the premarital educational program?" Fourteen out of the 20 individuals $(70 \%)$ said to leave it just the way it is. The 6 other responses were: "It should be more than once a week." "Couples should practice what was discussed in the sessions." "Have some group sessions with other premarital couples." "All couples should have a session with a multicultural counselor." "Include more group discussions." "Include more information on financial planning."

\section{Summary of the Evaluation}

The statements were understandable and answerable and each participant completed the statements to the best of his or her ability.

It is obvious that the program is very useful since 17 out of 20 (85\%) responded helpful (extremely or moderately) to every statement. The evaluation gives a clear indication that couples find this premarriage education program useful. Since I have combined materials, both original and borrowed, there is reason to believe that couples are not concerned about originality. It seems to me that couples are basically interested in a good premarital program. No one has ever questioned the origin of any of the materials. 
99

From this study I have concluded that a premarriage education program is necessary for each couple. 
CHAPTER 5

CONCLUSIONS

I cannot overemphasize the fact that anyone who is preparing for marriage should be introduced to a premarriage program. Needless to say, from the research presented I think ministers do a disservice to couples who are married without exposure to a premarriage educational model. The benefits of this program, clearly confirmed by the evaluation, are too impressive to be overlooked.

Following are some conclusions as this project is summarized:

1. I recommend a maximum of twelve yearly weddings as a comfortable number for a district pastor who will be administering premarital education.

2. If a couple decided that they do not want to be involved in premarital education, a pastor should feel comfortable to say, "Sorry, I cannot marry you." Pastors must understand that they are not obligated to perform every wedding. Pastors need to be both comfortable and confident that the couple standing before them on the wedding day has been prepared for this lifelong responsibility. They must never compromise their integrity. 
101

3. A pastor who is involved in premarital education should have a general knowledge of marriage and family life. This information can be obtained from reading a variety of literature on family life and exposure to audio and visual materials.

4. A premarital educator must be open. In making the experience practical for the couples, the educator must make appropriate self-disclosure which will bring meaning and clarity to the picture.

5. As the pastor seeks to remain contemporary, he needs to update his premarital materials as new statistics and current data are released.

6. There must also be a desire to be creative. The educator must find ways to substitute and/or create worksheets, seminars, and other resources to meet felt needs.

7. Great care should be taken to ensure that the local church is not financially handicapped with this project. This program incurs photocopying, video rentals, purchasing of inventories, and other lesser monetary costs. I recommend that each couple be asked to give a monetary gift to the church at the conclusion of the sessions. This has worked superbly for the Perth Avenue congregation.

8. The educator must be trustworthy. The couple will make themselves vulnerable if they have complete trust in the educator. The pastor who is not trustworthy will not 
attract couples to enlist in his program. When a couple finds a trustworthy educator, they will refer others to him/her. Mistrust is a bad omen in premarital education.

9. An educator who has a full quota of couples preparing for marriage should feel free to refer other couples to another educator with a proven and tried program. No pastor should be overloaded with premarital assignments.

10. After reviewing the literature on premarital education, I feel confident that the program for the Perth Avenue SDA Church is adequate. I have also gleaned ideas from the literature which I know will enhance the program at the Perth Avenue SDA Church.

11. In retrospect, I see the developmental process of this program. In so doing, I am able to appreciate the growth that has made this project possible.

12. From the results of the evaluation, the couples have expressed their satisfaction with the entire program. Although the majority have suggested no changes, I must be constantly on guard for new and updated information in the area of premarital education.

13. It is necessary for every pastor to have an updated referral 1ist. Couples may present situations which the pastor cannot handle. That is the time for him to make a referral.

14. Pastors should attend the annual Family Life Workshop (held at Andrews University) and any other 
conventions to sharpen his/her skills and to broaden the intellect in family life matters.

15. Pastors who are working on a premarital program should attend at least two Marriage Enrichment Seminars. These seminars will broaden his/her horizon in the area of family life and allow him/her to come to grips with life's vulnerabilities.

The following are indications for ministry:

1. It cannot be overemphasized that married life is still a desired lifestyle by a majority of today's population. Since this is a fact, there will always be a need for premarital education. The pastor needs to develop or procure a program to meet the need for premarital education.

2. If the church mandated that each pastor must implement a course of premarital education before performing a wedding, pastors would prepare themselves for this task.

3. When pastors understand that it is as necessary to prepare for marriage as it is for baptism because of our theology of "preparation," they will take this responsibility more seriously.

4. A trustworthy pastor will make lifelong friends with couples. He has been instrumental in sharing with them joys and sorrows and has participated in one of their most joyous earthly experiences. He has been charged with the 
responsibility of being a confidante. Couples find in this minister a lifelong counselor.

5. The couples who have received premarital education have generally requested post-marital nurture and care. The Perth Avenue SDA Church gave birth to a Couples' Club five years ago. Since that time, several similar clubs have come into existence. This is realistic follow-up for a premarital program.

6. Conferences should sponsor training and workshops in helping pastors to be exposed to, and in developing their own such programs.

7. Conference Ministerial Directors can make pastors aware of the literature and resources in the area of premarital education.

8. As a follow-up to this project, a manual, similar to the church manual and the ministers' manual, could be developed. This "black book" type manual would have sessions similar to the many suggested sermons for weddings in the minister's manual.

9. The Seminary should teach at least one course in preparing ministers to do premarital education. It is anticipated that ministers will perform weddings as part of their pastoral assignments. Some, depending on their location, will be expected to conduct several weddings yearly. This is the reason why I believe that every 
seminarian should be exposed to a proven and tested program before graduation.

In conclusion, the pastor/shepherd must make sure that the sheep are well cared for. The pastor must find green grass and cool water for thirsty sheep. Thus the pastor must find methods and programs to nurture and nourish all of his sheep, including those sheep preparing for marriage.

If this focus of preparation is kept central in the pastor's thinking, he/she will become sensitized to preparation for the kingdom of heaven, and in so doing he/she will prepare people for aspects of their sojourn on earth, including marital preparation. 


\section{APQENDICES}

Reproduced with permission of the copyright owner. Further reproduction prohibited without permission. 
APPENDIX I

FIRST SESSION

Reproduced with permission of the copyright owner. Further reproduction prohibited without permission. 
MARRIAGE INFORMATTON

HIS NAMF:

ADDRESS:

TEI.EPHONE:

DATE OF BIRTH:

AGE:

LANDED IMMIGRANT: $\square$ YES $\square$ NO

CITUENSHIP:

PLACE OF BIRTE:

CHURCH AFFILLATION:

FATIIER'S VAMI:

FATHER'S RIRTHPLACE:

MOTIER'S MAIDEN NAMT:

MOTIIER'S BIRTHPL,ACE:

PRESENT STATUS: $\square \mathrm{M} \quad \square \mathrm{S} \quad \square \mathrm{D}$

OC.CIIPATTON:
HER NAME:

ADDRESS:

IELEPHONE:

DATE OF BIRTH:

AGE:

LANDED IMMIGRANT: $\square$ YES $\square$ NO

CITIZENSHIP:

PLACE OF BIRTII:

CHURCH AFFLIATION:

FATHER'S NAME:

FATIIER'S BIRTHPI.ACE:

MOTHFR'S MAIDEX NAME:

MOTHFR:S RIRTITPLACE:

PRESENT STATUS: $\sqsubset \mathrm{M} \square \mathrm{S} \square \mathrm{D}$ OCCUPATION:

PROPOSED DATE OF WEDDING:

PLACE OI WI:DIING:

REHERSAL DAIL:

TIME OF WEDDING:

PI ACF. OF RECE:TIUN. 


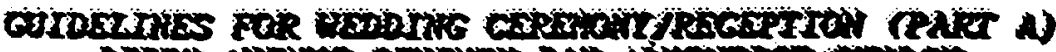

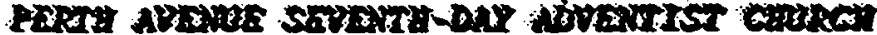

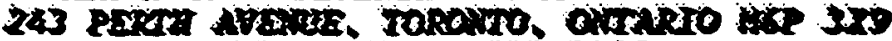 \\ retritive: $535-290$}

The Perth Avenue Seventh-Day church is please to offer its services and facilities for wedding ceremonies and receptions. This Church is dedicated exclusively to the service of God. As Seventh-Day Adventists, we believe in the sacredness of marriage and therefore approach the sanctuary and the service of the holy matrimony with a feeling of profound reverence and respect to God. We require that all couples and their guests abide by the guidelines set out in this form.

\section{REVERENCE:}

We especially caution against profanity, that is showing irreverence toward sacred things. Smoking and alcoholic beverages are specifically prohibited on church property. While we respect peoples' customs, the throwing of rice or confetti in the Church will not be permitced. Wedding gowns and the atcire of those in the wedding party should be modest to reflect the sacrediness of the Church and the service. Head gears worn by males must be removed before encering the church. The music should be of a sacred nature. The use of nails, tacks, scotch tape or clamps on woodwork or furniture is prohibited.

\section{CLEAN-UP:}

1. That the couple make the necessary arrangements to ensure that the premises (sanctuary, lower hall and kicchen) be cleaned after the function.

2. Tables and Chairs - that the tables and chairs set up, be put away after use.

\section{FINANCIAL ARRANGEMENTS:}

Non-members of the Perch Avenue S.D.A. Church will pay:-

1. Rent for use of Sanctuary $\$ 200.00$

2. Custodian fee (cleaning and waiting

cime for 4 hours)

$\$ 100.00$

3. Use of lower hall and accessories $\$ 300.00$

4. Damage and clean up deposit $\$ 100.00$

(100\% refundable if no damage is incurred)

and the clean up is done

5. Excra facilities (audio recording)

Fee will vary

Grand TotaI

$\underline{\$ 700.00}$ 


\section{Church Members will pay:-}

1. Fee for Sanctuary

2. Custodian fee

3. Lower hall

4. Damage and clean up fee (100\% refundable if no damage is incurred) and the clean up is done

Grand Total

$\$ 100.00$

$\$ 100.00$

$\$ 200.00$

$\$ 100.00$

\section{Note:}

(Church members are expected to support the church with tithes and offerings.)

Church Board

Perch Avenue S.D.A Church

MAY 1992

Reproduced with permission of the copyright owner. Further reproduction prohibited without permission. 
APPENDIX II

SECOND SESSION

Reproduced with permission of the copyright owner. Further reproduction prohibited without permission. 


\section{PREPARING FOR MARRIAGE INVENTORY}

A Questionnaire for Engaged Couples

\section{Instructions}

- Without consulting your fiance(e) fill in the assigned section(s) as completely as possible.

- Don't be concerned with the "rightness" or "wrongness" of your answers. Your personal opinion and viewpoint is what counts.

- Be as thorough and honest as you can.

(C) 1985

Home and Family Services

General Conference of Seventh-day Adventists 


\section{PART I-SEECTING A LIFE PARTNER}

1. Do you Agree or Disagree with the following? (Circle your answer) Key: $S D=$ Strongly Disagree; $D=D i s a g r e e ; N S=N o t$ Sure; $A=A g r e e ; S A=5$ trongly Agree.
a. There should not be a great difference in age between marriage partners.
b. A couple facing marriage should get advice from their parents regarding the new couples' hopes and plans.
c. In selecting a marriage partner an important question to ask is "Will this marriage increase my love for God?"
d. A good way to determine the character of a prospective husband is to consider his relationship with his mother.
SD D NS A SA
SD D NS A SA
e. Every wife should be trained in some business whereby, if necessary she could earn a living.
SD D NS A SA
f. Physical appearance should be a determining factor in mate selection.
SD D NS A SA
SD D NS A SA
SD D NS A SA

2. List several reasons why you have selected your fiance(e) as your prospective wife/husband.
a.
b.
c.
d.

3. Identify some qualities that you are bringing to your marriage that will be assets to it.
a.
b.
c.
d. 
4. Identify some qualities that your fiance(e) is bringing to your marriage that will be assets to it.
a.
b.
c.
d.

5. Some ways you and your fiance(e) are different are:
a.
b.
c.

6. Some ways you and your fiance(e) are alike are:
3.
b.
c.

7. Some weaknesses already existing in your relationship are:
a.
b.
c.

8. Some areas where you are really strong are:
a.
b.
c.

\section{PMI 3}

Reproduced with permission of the copyright owner. Further reproduction prohibited without permission. 
9. Rate yourself by circling the number that best applies to you:

\begin{tabular}{|c|c|c|c|c|c|c|}
\hline & & $\begin{array}{l}\text { Very } \\
\text { False }\end{array}$ & False & Undecided & $\begin{array}{l}\text { Very } \\
\text { True }\end{array}$ & True \\
\hline a. & $\begin{array}{l}\text { He/she is physically attrac- } \\
\text { tive to me. }\end{array}$ & 1 & 2 & 3 & 4 & 5 \\
\hline b. & $\begin{array}{l}\text { I don't feel defensive or } \\
\text { embarrassed by his/her physical } \\
\text { characteristics. }\end{array}$ & 1 & 2 & 3 & 4 & 5 \\
\hline c. & $\begin{array}{l}\text { We agree on the things } \\
\text { worth sacrificing for in life. }\end{array}$ & 1 & 2 & 3 & 4 & 5 \\
\hline d. & $\begin{array}{l}\text { We are both committed } \\
\text { Christians. }\end{array}$ & 1 & 2 & 3 & 4 & 5 \\
\hline e. & $\begin{array}{l}\text { I have known him/her long } \\
\text { enough and well enough that } \\
\text { I have discovered our in- } \\
\text { evitable points of disagreement. }\end{array}$ & 1 & 2 & 3 & 4 & 5 \\
\hline f. & $\begin{array}{l}\text { I respect his/her mental } \\
\text { ability. }\end{array}$ & 1 & 2 & 3 & 4 & 5 \\
\hline g. & $\begin{array}{l}\text { I will need to help my partner } \\
\text { change in some ways after } \\
\text { marriage. }\end{array}$ & 1 & 2 & 3 & 4 & 5 \\
\hline h. & $\begin{array}{l}\text { I am confident that our marriage } \\
\text { will be a happy one. }\end{array}$ & 1 & 2 & 3 & 4 & 5 \\
\hline
\end{tabular}

10. Have you ever wished you had not become engaged? (Circle your answer)

Never Once Occasionally Frequently

If so, why?

PMI 4 


\section{PART I-VALUES AND GOALS}

1. Write dowl. five things in life that you value very much, in the order of their importance to you.
a.
b.
c.
d.
e.

2. In the context of the following categories outline the goals you have for your marriage. Be as specific as you can.

a. Education/Training

b. Job/Career

c. God/Religion

d. Church

e. Money

f. Possessions

g. Family/Children

PMI 5

Reproduced with permission of the copyright owner. Further reproduction prohibited without permission. 

h. Leisure
i. Other (Specify)

3. The above categories of goals were listed randomly.

a. Relist them by categories according to your priorities.
1.
2.
3.
6
4.

b. Relist them by categories according to the way you think your fiance(e) would list them:

1.

2.

3.

4.

5.

6.

7.

8.

4. Choose one of the above categories. Write your selection here:

a. What specific plans will be necessary to reach it?

b. How soon do you think the goal should be reached? (Circle your answer) Immediately Within I year Within 5 years Within 10 years 10 years or more

c. How do you think you will feel if plans do not work out to reach the goal when and how you had hoped? 


\section{PART III-LOVE AND FEELINGS}

1. Do you Agree or Disagree with the following? (Circle your answer) Key: $S D=$ Strongly Disagree; $D=D i s a g r e e ; ~ N S=N o t$ Sure: $A=A g r e e ;$ SA $=$ Strongly Agree.
a. Open expressions of love tend to show the weaker side of one's character, and it is thus better to be more reserved.
SD D NS
A SA
b. Love once expressed need not often be repeated as long as it is understood between marriage partners.
c. A sacred circle surrounds each married couple and one or the other should not share the confidences of their marriage with those outside of it.
d. Love is a feeling.
e. Good Christians don't get angry.
SD D NS A SA
SD D NS A SA
SD D NS A SA
SD D NS A SA

2. State several things that you are going to do after marriage to help the love between you and your partner to grow.
a.
b.
c.

3. List the things that you would like your partner to do to show his/her love for you.
a.
b.
c.
d.

4. Complete:

"Sometimes I just want to be left alone. Usually that is when 


\section{Complete:}

"Some diversions or escapes I use in my life are

6. Complete:

"When I am hurt, I would appreciate it if you

7. Complete:

"When you are hurt, I would appreciate it if you

8. Circle the answers that best describe your feelings:

A. I am hurt most when you

1. pay more attention to your work and studies than to me.

2. don't keep up your appearance.

3. are careless about money.

4. embarrass me publicly.

5. do all the talking.

6. leave everything up to me.

7. don't listen to me.

8. go out too much with your "fiiends."

9. nag me.

10. when you want too much from me physically.

11. use slang or swear words in your conversation.

i2. don't share the same spiritual values that I share.

B. When I am hurt I tend to

1. withdraw from you.

2. do something to hurt you.

3. get angry at you.

4. play the "martyr."

5. talk it out gently.

6. get in a mood.

7. keep myself busy.

9. Complett:

"If in their marriage a couple found their love to be waning they should 
10. Recall some instances when you were angry.
a.
b.
c.

11. When you are angry, what do you do? (Check the answer which best describes your usual response.)

a. Try to keep it under control.

b. Get it off my chest--explosively!

c. Ignore it; try to pretend I'm not.

d. Acknowledge my feeling and seek to rationally work out the difficulty.

12. Pinpoint the thing or things in life that cause you to worry the most.
3.
b.
c.

13. List several things that make you feel worthwhile.
a.
b.
c.
d.

14. List several things that make your fiance(e) feel worthwhile.
a.
b.
c.
d.

PMI 9 


\section{PART IV-RELIGIOUS BELIEFS AND EXPECTATIONS}

\section{Complete:}

"Marriage is a fitting symbol of the relationship between Christ and His church because

2. Circle the answer(s) which you feel are appropriate:

The Bible describes a man and a woman in a marriage relationship as being "one flesh." This means that:

a. the woman loses her individuality.

b. the man loses his individuality.

c. they are to unite sexually.

d. they complement each other.

e. they have the same feelings about things.

f. they are to make a lifelong commitment to each other.

g. they are joined into a new entity by God.

h. none of the above.

3. Do you Agree or Disagree with the following: (Circle your answer) Key: SD=Strongly Disagree; $D=$ Disagree; NS=Not Sure; $A=A g r e e ;$ SA=Strongly Agree.
a. Husband and wife are equal.
$\begin{array}{lllll}\text { SD } & D & \text { NS } & A & \text { SA } \\ \text { SD } & D & \text { NS } & \text { A } & \text { SA }\end{array}$
b. The husband should lead in family worship.
SO D NS A jA
c. Marriage is a permanent relationsiip.
SD D NS A SA
d. A good order of priorities in a home would be God first, the church second, marriage third and family fourth.
e. Husbands and wives have individual rela- tionships with God, so it is not really important that they pray together.

$\begin{array}{lllll}\text { SD } & D & \text { NS } & \text { A } & \text { SA } \\ \text { SD } & D & \text { NS } & A & \text { SA } \\ \text { SD } & D & \text { NS } & A & \text { SA }\end{array}$
9. A couple should expect growth in marriage $\quad$ SD $D$ NS A SA to continue for a lifetime. 
4. List some ways that you think the church can be helpful to your marriage.
a.
b.
c.
d.

5. Complete:

"Spiritually, I expect from you (my prospective wife/husband)

6. Describe in a few sentences your belief about Jesus Christ.

7. Complete:

"The times when I feel good about myself are

8. Complete:

"The times when I feel unsure, discouraged, not so valuable are

9. Things my fiance(e) can say and do that lift my sense of personal worth:
a.
b.
c.
d.

PMI II

Reproduced with permission of the copyright owner. Further reproduction prohibited without permission. 
1. Do you Agree or Disagree with the following? (Circle your answer) Key: SD=Strongly Disagree; D-Disagree: NS=Not Sure; $A=A g r e e ;$ $\mathrm{SA}=$ Strongly Agree.

a. Since the wife is assigned the subordinate position in marriage, she is not on an equal basis with man.

b. Doing "woman's work" robs a husband of status.

$\begin{array}{lllll}\text { SD } & D & \text { NS } & \text { A } & \text { SA } \\ \text { SD } & D & \text { NS } & A & \text { SA } \\ \text { SD } & D & \text { NS } & A & \text { SA } \\ \text { SD } & D & \text { NS } & \text { A } & \text { SA }\end{array}$

d. The husband and father is head of the household.

e. Husband and wife should never criticize each other's plans or question each other's

SD D NS A SA
judgment in the presence of others.

f. Marriage means that usually one partner or the other will have to sacrifice his individuality to some degree.

g. A wife may combine a career and homemaking.

h. Some jobs in a household are definitely SD D NS A SA ferminine, others definitely masculine.

2. List several ways in which you treat your partner as your equal.

a.

b.

c.

3. Complete:

"To me Ephesians 5:22-25 means 


\section{PART VI-COMMUNCATION AND CONFUICT RESOLUTION}

1. Do you Agree or Disagree with the following? (Circle your answer) Key: $5 D=S t r o n g l y$ Disagree; $D=D i s a g r e e ; ~ N S=N o t$ Sure: $A=A g r e e ;$

$\mathrm{SA}=$ Strongly Agree.
a. Married couples should keep no secrets from each other.
SD D NS A SA
SD D NS A SA
b. Disagreements usually are settled by one partner or the other giving in.
SD D NS A SA
c. Most marriage communication problems are caused by the couple not taking time to be with each other.
d. If a couple should discover themselves mismated and miserable they ought still to make the best of their situation.
e. Both husband and wife should be willing to yield his or her way or opinion.
SD D NS A SA
f. Usuaily the husband should make the final decision when he and his wife cannot agree upon a decision that must be made.

$\begin{array}{lllll}\text { SD } & D & \text { NS } & \text { A } & \text { SA } \\ \text { SD } & D & \text { NS } & A & \text { SA } \\ \text { SD } & D & \text { NS } & A & \text { SA }\end{array}$

2. Some things we don't seem to be able to communicate about are:
a.
b.
c.

3. Complete:

"important decisions in our marriage will be made

4. Circle the answer you think is best:
a. Do you wish your fiance(e) would listen to you more?
Always Sometimes Seldom Never 
b. When talks to you, do

Always Sometimes Seldom Never you try to make him or her think you are paying attention when you are not?

c. Can you feel comfortable for your fiance(e) to have ideas on certain Always Sometimes Seldom Never subjects that do not agree with yours?

5. Multiple choice:

"When I pray I

a. share openly and honestly with God.

b. feel uncomfortable and anxious.

c. take time to listen.

d. feel comfortable and relaxed.

e. other

6. If you and your future wife/husband get involved in a disagreement, argument or conflict, what will you do to resolve it?

7. After a disagreement who initiates the first move to make up?

8. Some things my fiance(e) and I disagree about are:
a.
b.
c.

PMI 14 


\section{PART VII-DHAWS}

1. Describe your parents' attitude toward your marriage.

Favorable Unfavorable I'm not sure

2. Describe your future in-laws' attitude toward your marriage.

Favorable Unfavorable I'm not sure

3. Do your parents and your fiance(e)'s parents like each other?

Yes No If "No," explain how you will relate to this.

4. What are some of the wishes of both families which you intend to include in your wedding plans?

5. If you felt your in-laws were "meddling" in your lives what would you do?

(Check your reponse, whether or not you think it is ideal)

\begin{tabular}{ll} 
Move away \\
Tell them off \\
Become very defensive \\
Not speak to them \\
Get angry \\
Try to reason with them \\
Just accept it \\
Not visit them anymore \\
Pray about it \\
Talk to them honestly and forthrightly \\
\hline-
\end{tabular}

6. Do you Agree or Disagree with the following? (Circle your answer) Key: $S D=$ Strongly Disagree; $D=$ Disagree; $N S=$ Not Sure: $A=A g r e e ;$ SA=Strongly Agree.
a. It is appropriate for in-laws to live with their married children.
SD D NS A SA
b. A couple should get advice periodically from their in-laws.
SD D NS A SA 
c. Equal amounts of time should be spent

SD

D NS A. SA with the in-laws at vacation time.

d. It's all right to accept money from

SD

D NS A SA in-laws.

e. Marriage partners should do what brings happiness between them even if it disturbs

SD D NS A SA their parents' happiness.

7. Describe two things about your future mother-in-law and father-in-law that you really like.

Mother-in-law

a.

b.

Father-in-law

a.

b.

8. Describe two things about your future mother-in-law and father-in-law that you do not like.

Mother-in-law

a.

b.

Father-in-law

a.

b.

9. What do you plan to do about the items mentioned in \#B above?

10. Complete the following statements:

"In-laws

11. "If I should become a mother-in-law/father-in-law

PMI 16 
5. Will you use contraceptives?

Yes No Uncertain

6. Do you plan to have children?

Yes No Uncertain

7. How does your future wife/husband feel about your plans for children?

$\begin{array}{ll}\text { a. } & \text { Strongly Disagrees } \\ \text { b. } & \text { Disagrees } \\ \text { c. } & \text { Not Sure } \\ \text { d. } & \text { Agrees } \\ \text { e. } & \text { Strongly Agrees } \\ \text { f. } & \text { Other }\end{array}$

8. How many children would be ideal for you?

9. When do you plan for your first child to be born?

Your Second?

Others?

10. Complete the follo ving to include your beliefs and feelings:

"Abortion is 


\section{PART $X \rightarrow$ HEALTH AND HABITS}

1. Do you Agree or Disagree with the following statement:

The state of one's health has little to do with marital happiness.
Agree
Disagree
Uncertain

2. How would you rate your present overall state of health?

$$
\text { Poor Fair Good Above Average Excellent }
$$

3. In which of the following areas have you ever experienced ill health?

$\begin{array}{cl}\text { a. } & \text { Physical } \\ \text { _b. } & \text { Mental } \\ \text { c. } & \text { Emotional } \\ \text { d. } & \text { Spiritual } \\ \text { _e. } & \text { None of the Above }\end{array}$

4. Complete the following: (use reverse side for added space)
a. I feel best physically
b. I feel worst physically
c. Mental health
d. Meal preparation
e. My prospective spouse's health
f. To improve my health I will
9. My fiance(e) can help me in my emotional development by

5. Does your fiance(e) have any habits that are annoying to you? Yes No Uncertain If "Yes," list them and indicate how you
plan to relate to these 
6. Do you think you have any habits that are annoying to your fiance(e)?

Yes No Uncertain

If "Yes," list them and indicate what you plan to do about these.

PMI 22

Reproduced with permission of the copyright owner. Further reproduction prohibited without permission. 


\section{PART XI-FAMI Y BACKGROUND}

1. On the continuums below place an $(x)$ to rate the family atmosphere of the home in which you grew up.

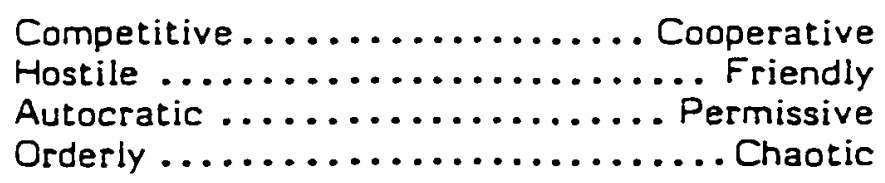

2. Check the appropriate column regarding the home in which you grew up:

\section{Always Usually Sometimes Never}

We worked things out together.

It was o.k. to share feelings.

There was freedom to make choices and learn from mistakes.

I felt listened to.

All family members were treated as equals.

Everyone's ideas were important.

I was allowed to do pretty much as I pleased.

I was afraid of my father.

I was afraid of my mother.

I was in conflict with someone.

I felt "put down."

3. Rate the following according to the way they were felt about in your family.

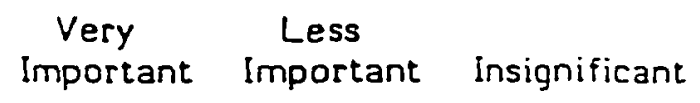

\section{Athletics/physical fitness}

Academic achievement

Music

Money

Accumulating goods

Hard work 
Education

Very
Important Important Insignificant

Power

Control

Winning

Religion

Cleanliness

Respect for others

Forgiveness

4. In my family I was: _eldest, _ _second, _middle, _youngest, the only child.

5. Describe what your relationship with your father was/is like.

6. What similarities are there between you and your father?

What differences?

7. Describe what your relationship with your mother was/is like.

8. What similarities are there between you and your mother? 
What differences?

9. Describe any similarites and differences you see between your fiance and your father/your fiancee and your mother.

What differences?

10. What similarities will exist between the family you came from and the family you will be establishing?

What differences?

PMI 25

Reproduced with permission of the copyright owner. Further reproduction prohibited without permission. 


\section{PART XII-PREPARING FOR REMARRIAGE}

1. List the key reasons why you have decided to marry again:
a.
b.
c.
d.

2. Some things I learned about myself from my previous marriage:
a.
b.
c.
d.

3. Describe any changes which have come about in your life since the time of your previous marriage.
a.
b.
c.
d.

4. What similarities exist between the expectations you had for your previous marriage and those you have for your next marriage?
a.
b.
c.

What differences?

a. 
b.

c.

5. About my prospective marriage my children feel

6. Indications I see in my life that healing of the hurt and pain brought about by the ending of my first marriage is taking place:
a.
b.
c.

7. Some challenges I will face in a new relationship because of carry-overs from the past are:
a.
b.
c. 
List any fears you have as you prepare for marriage.

1.

2.

3.

4.

5.

6.

7.

8.

9.

10. 
1. Things I appreciated in my previous marriage.

(a)

(b)

(c)

(d)

(e)

2. Things I did not appreciate in my previous marriage.

(a)

(b)

(c)

(d)

(e)

3.

Why I think my marriage failed?

(a)

(b)

(c)

(d)

(e)

4.

What I plan to do to avoid these failures from recurring.

(b)

(c)

(d)

(e) 

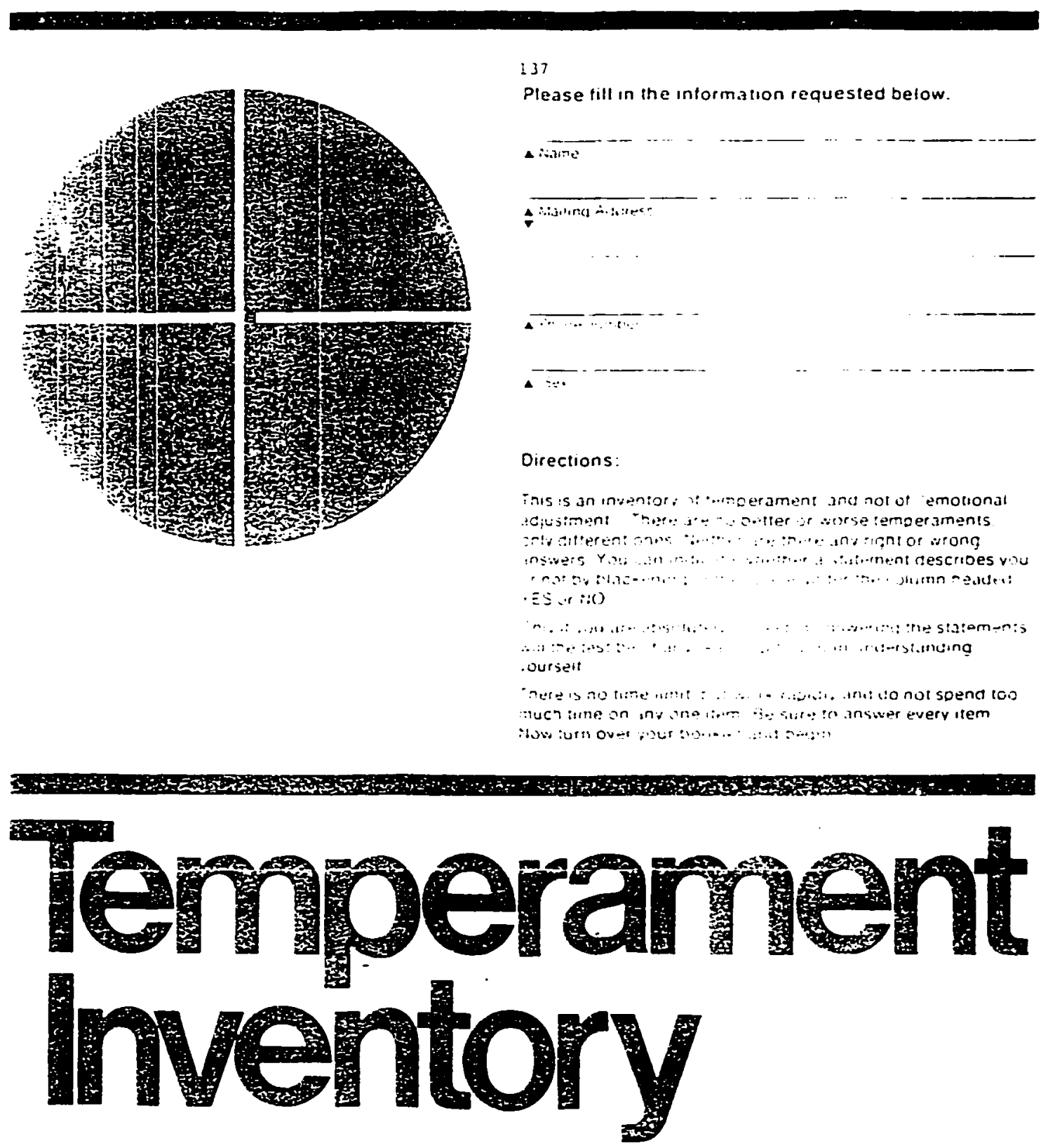

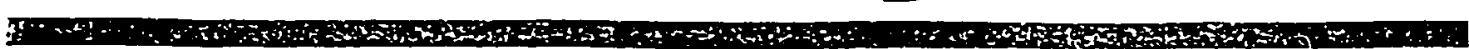

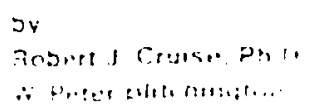

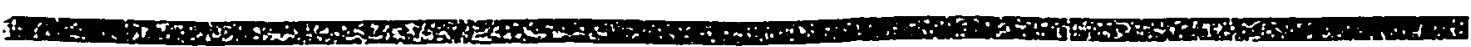

Reproduced with permission of the copyright owner. Further reproduction prohibited without permission. 
APPENDIX III

THIRD SESSION 


\section{Before You Say "I Do"...}

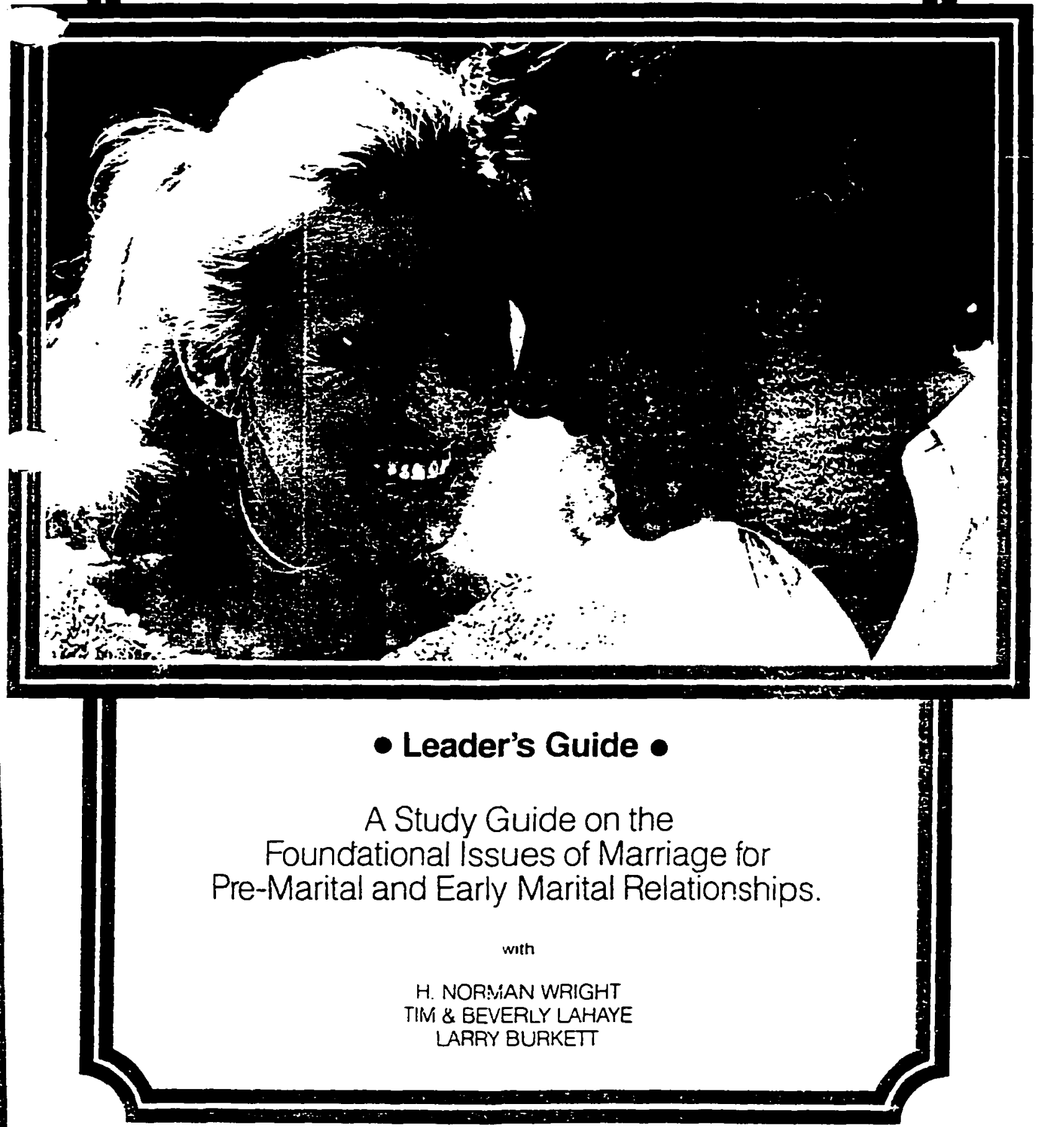

Reproduced with permission of the copyright owner. Further reproduction prohibited without permission. 
APPENDIX IV

FOURTH SESSION

Reproduced with permission of the copyright owner. Further reproduction prohibited without permission. 


\section{BIBLIOGRAPHY FOR NEWLY WEDS}

THE ACT OF MARRIAGE

Iim \& Beverley Lattaye

IF ONLY HE KNEW

Gary Smalley

ANSWERS TO YOUR FAMILY'S FINANCIAL QUESTIONS

Larry Burkett

TO HAVE AND TO HOLD

Nancy Van Pelt

COMMUNICATION: KEY TO YOUR MARRIAGE

H. Norman Wright

THE SEXUAL WOMAN

Mary Ann Mayo \& Joseph L. Mayo

ENERGIZE YOUR LIEE THROUGH TOTAL COMMUNICATION

H. Norman Wright

INTENDED FOR PLEASURE

Ed Wheat \& Gaye wheat

THE COMPLETE FINANCIAL GUIDE FOR YOUNG COUPLES

Larry Burkett

THE MARRIAGE YOU ALWAYS WANTED - BUT NEVER THOUGHT YOU COULD HAVE Ed Anderson

GOOD MARRIAGES DON'T JUST HAPPEN

O. Dean Martin

THE BIRTH ORDER BOOK

Dr. Kevin Leman

IF ONLY HE RNEW

Gary Smalley

SOLVING MARRIAGE PROBLEMS

JaY E. Adams

MARRIAGE TAKES MORE THAN LOVE

Howard \& Jeanne Hendricks

UNDERSTANDING THE MALE TEMPERAMENT

Tim Lat iaye

FOR BETTER OR FOR BEST

Gary Smalley

THE FIRST YEARS OF FOREVER

Ed Wheat

Reproduced with permission of the copyright owner. Further reproduction prohibited without permission. 
WEDOING PRAYERS

TRADITIONAL

1. Heavenly Father, we ask for Thy divine sanction on tris sarvice which has ; conducted in Thy name. May Thy blessing rest on and as ther face life together and with Thee. May their home be Duilt according to :r: divine pattern and may their love be a "little bit of heaven." For we arz : in Jesus' name, Amen.

2. Heavenly Father, Thou source of all true love and devotion, wilt Thou ble this couple as they take their vows of fidelity to each other. Nilt Tho's keep them true to each other and to Thee. Witt Thou Jless them in their Christian life and their Christian service; and wilt Thou lead then gently through their trials and Derolexities of life. May the Spirit ever be their companion and guide, in Jesus' name we ask, Amen.

3. Heavenly Father, Thou sourse of all love and happiness, wilt Thou seal with Thy Divine olessing the vows that have been made in Thy presence. Wilt Thou guide and in their lives together that they may find fulfillment. companionship and satisiying service. May this new chapter in their lives be written iull of beauty and meaning. May the grace of God and love of Christ and the fellowship of the foly Spirit be theirs now and forever more. Amen.

4. Our heavenly Father, you ordained the holy estate or marriage, and two of your own, and have come to this church to give thenselves to each other. We ask, now, your blassing upon their lives as they begin their li ie together. Ne orav, Father, that strong cords of love may bind them to each other, ihat in all of life's experiences they may de as one.

Give ro risis marriage, we oray, times of raal hasoiness and occasions of deep joy. Mav their liós ackncwledge with praise that sucn noments are gifts from Your hend.

We know, our father, that all of life cannot je pleasant. But we aiso know that your grace is sutficient, and that it is always availaole to vour caildren. Create is inis narriage a spiritual reservoir from anich each can craw when the inoleasant comes and when life seems to be unreasonable. ive give them now is your care. Nurture their love for eact, otner, and for you.

These things we ask in the name of Jesus Etrrist, our Lara. Amen.

इ. Sur -olv and righreous heavenly Father, cefore whom these jol em: yows si love

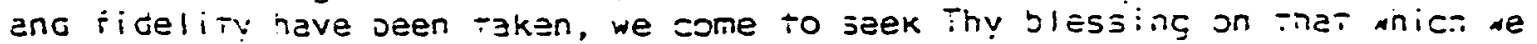
nave Jone in thv name. is he founieticns of jnother Ghristizr home heve zes?

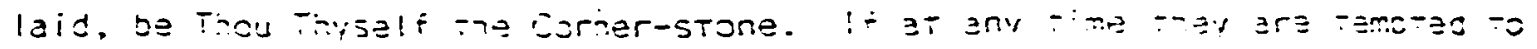
iorget thee, or to becsme inditferent to each other, Jear Eather, taveal ra them thy rasiraining love. Euide them by Thy soirit and uonole riem by thy grace. imen. 
5. Our holy and righteous heavenly Father, before whom these solemn vows of love and fidelity have deen taken, we come to seek Thy blessing on that which we have done in Thy name. Look Thou in love and tenderness upon these Thy children. As the foundations of another Christian home have been laid, be Thou Thyself the unseen Guest at every meal, the Companion in every experience. If at any time they are tempted to become careless in Thy service or indifferent to the needs of each other, then dear Father, reveal Thyself to them in all Thy restraining love and kindly correction. Guide them by Thy spirit and bring a revelation of Thy love to other hearts and homes. And through their united ministry of love may they extend the knowledge of the Saviour. Keep their eyes heavenward looking ever, for the soon return of Jesus their Lord and Saviour. And give them at last a welcome home into the eternal kingdom of Thy light and love. These things we ask through Jesus Christ our Lord. Amen.

7. Our holy and righteous heavenly Father, before whom these solemn vows of love and fidelity have been taken, we ccme to seek Thy blessing on that which we have done in Thy name. Look thou in love and tenderness upon these Thy children. As the foundation of another Christian home has been laid. be Thou Thyself the unseen Guest, The Companion in every experience. If at any Time they are tempted to forget Thee or to become indifierent to each other, then, dear Father, reveal Thyself to them in all Thy restraining love. Guide them by Thy Soirit and uohold them by iny grace. Keed their eyes ever heavenward, lock:ng ior the return of Jesus their Lord and Saviour.

O periect love, 311 human thought transcending,

Lowly we kneel in srayer jefore Thy throne.

That theirs may be the love wion knows no ending, whom thou forevermore cost join in one.

O perfect Life, be Thou ineir full assurance

of tender charity anc sieadfast faith,

of zatient hooe, and wuiet, orave encurance.

with child..like rust that iears nor pain, nor deat?.

Brant inem ine jov wnich orignienos eartnly sorraw;

Grant them the peace wnich calms all earthly strite;

And to $1 i$ íe's day the glorious unknown morrow

That Jawns uoon eternal love and life. Amen.

3. Most merciful and gracious God, bestow upon these Thy servants the seal of

Thine aporoval, and Thy iatnerly benediction, granting unto inem graca to isifill, with sure and sieadiasi devotion, the covenant iney have mace jefore Thee. Guide them rogetner, we oray thee, in the way of righteousness and secce, that loving and serving thee with one heart and nind, 311 the Jays of ineir life, they may be zoundantly enricheo with the tokens gi ine divine love. Amen. 
9. We invoke Thy blessing, sur Father, unon these who have this day oledged their 10:e one to the other. We pray Thee to make their love strong, holy and deathless, so that nothing may guench the heavenly light that no glows within them.

Grant them soder eyes to look beyond these joyous days to the years of service and the ages of eternity. May the transforming power of love ricen and ennoble their lives, and may the home here established be a light in the worid. Amen.

10. O God of love, to Thee we box, And pray for these before thee now. That closely knit in holy vows They may in Thee be one.

When days are filled with oure jelight, When paths are olain and skies are bright, walking oy izith and not by signt, May they in Thee be one.

When stormy winas suliill iny wi!!

And $\exists 11$ their gocd seems -urned to i!l

Then, irusting Thee scmolerelv still,

May they in Thee be cne.

Whate'er in lite snall be rneit share

of quickening jov or zurzening zare.

In sower to do and grace to jear.

In Dower to do and grace is bear,

tay rney in Thee be one.

Etorial Love, with rnem azise:

1.: Thee forever nav iney ni

For even Jeeth gannot givise

Those wnom inc manest ine. imen.

il. 3rid are saunting on you! They are zware thet rou will hot let Fiem Jown. BuT, in a world where the sacreoness ot -ne home is jast disas-

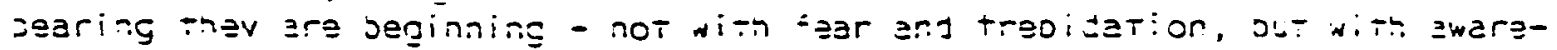
-ess that xitrout your assistance heir cnances ji slcsess ara slim. tarj,

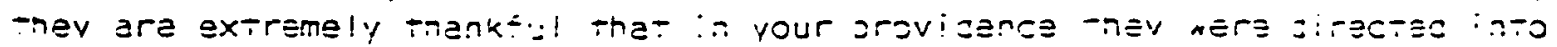

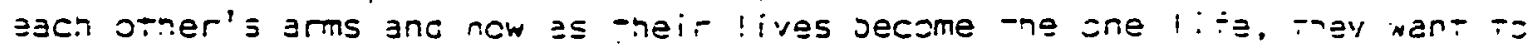
live so to live that ri.s rome wil! ye continual rest:mony gi rianktuiness. se request your nelo -or them rnat: Their love wiil se sa-ient znc kine. nct jealcus and bcasti-ii, nor arrogant and rude that theit love will hot insist on having its own wav - not de enivable and resent-ijl. Jut that their love will oear a!l things, delieve all inings, ncde for all inings,

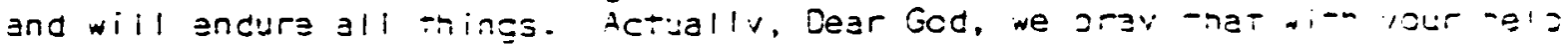
-neir love wiil never ans. In christ imen. 
12. "O God of Love. Thou hast established marriage for the wel fare and hapoiness of mankind. Thou has said. 'It is not good for man to be alone. I will make a help meet for him." Now our joys are doubled since the hapoiness of one is the happiness of the other. Our burdens now are nalved since when we share then we divide the load.

3less this husband. Bless him as provider of nourishment and raiment and sustain him in all the exactions and pressures of his battle for bread. May his strength be her protection, his character be her boast and her pride, and may he so live that she will find in him the haven for which the heart of a woman truly longs.

Bless this loving wife. Give her a ienderness that will make her great, a deep sense of understanaing, a great faith in Thee. Give her that inner beauty of soul that never fades, that eternal youth that is found in holding fast the things that never age.

Teach them that marriage is not living merely for each other: it is two uniting and joing hands to serve Thee. Give them a great spiritual purpose in life. May they seek first the kingdom of God and His righteousness, and the other rnings sinall be added unio Them.

May they not expect the sertection of eacn other that delongs along to Thee. May they minimize eacn other's weaknesses, be swift to oraise and magnify each other's zoints of scmliness and strength, and see each other through a lover's kind and patient eyes.

Now make such assignments to them on the scroll si Thy will as will oless them anc develOD ineir snaraciers as They walk togerner. Give rnem enough tears to keep them tender, enougn huts to kees inem humane, enough of tailures to keeo their hands clencned igntly in Thine, and enough of success to make inem sure iney walk with Goc.

May they never take each other's love ior granted, Jut always experience that oreatnless woncer inat exclaims, "Out of all this worla vou have cnosen me."

When life is Jone and the sun is setting, nay thev be surs then as now still nano in hano, still thanking God for each orher. Nay they sarve Thee nadoily, iaithfully, together, until at last one snall lay the other into the arms of God, or until jesus comes.

Tine Lord bless thee and keep thee: the Laro make ris ilace to sine yoon thee and be gracious unto inee. The Lor $1 i$ it tis countanance doon thee and give thee beace, now and ever more. Amen.

13. Dear God: In the nacoiness of this moment we come to ycu incividually-ais and sted out, not as they came into your oresence this atrernoon, DUT now as "one"--joined together not by man and is laws and zustams, Jut zy you. They nave not rusied into this relatiorsnis their jersonalities have become known to each other. They see their Jif ierance as well as their similarities. They also recocnize their need ist cepencence uoon vou. Their jltimate joal is heaven--not for the gai.? it will bring, out for the exoerience ot raunion with ycu. Juide them in ever! experience of 1 ìe, is ny orzver, rnrougn Jesus birist. Amen. 
if. Jear Goo: Two hearts we present to you this afternoor. rearts tilled wirn love for sach other, icr you and otners. and

are not oi ind, Lord to the potential hazarjs of life 35 nusband and vite, but neither are they about to coubt or despeir with uncertainty for the future. They are determined to make, thouç your aid, their sossibilities and zotential, realities, they have endeavored to open themselves to each other--allowing each to see their individual strengthis and weaknesses. They see similarities and differences in temperment and personality, but they have already begun to make adjustments in their own lives which with their dependence upon Your interest in them they feel will insure the success of their partnership and success in experiencing eternal cartnership with You through Jesus Christ, Amen. 


\section{Tradiflonal}

1. And now, that you cake this women, , to be your lawfully , do you solemily and sincerely declare wedded wfe, to love and to cherish her from this day forward, in sickness or in health, in adversity or in prosperfty and forsaking all other, will keep yourself wholly wro her, so long as you borh shall live?

And do you, you take this man, , solemnly and sincerely declare that , to be your lawfully vedded husband, to love an t to cherish hin from this day forward, In sickness or in health, in adverstey or in prospertey, and forsakting all orhers, wlll you keep yourself wholly unco him so long ag you boch shall llve?

2. And now, - do you solemaly promise before God and these wirnesses that you will cake to be your lawfully wedded wife, to live cogether after God's holy ordinance in the sacred estace of macrtmony as long as you boch shall live?

And now do you, , take this man, to be your lawiully wedded husband, to live cogether after God's holy ordinance in the sacred estate of satefmony so ong as you both shall live?

3. Solemily promising before God and in the presence of these winesses, wilt thou, , have this vomen, to be thy wedded whe, to live cogether after God's ordinance in the sacred estace of sacrimony? Wilc thou love her in sicksess and in health, in prosperity or adverstey and forsaking all other, and the thought of all orher, keep thee only unco her as long as je borh shall live? Do you so declare?

W11t thou, - have chis nax, to be thy wedded husband, to live together arter God's ordinance in the sacred estate of matrimony? Wilt thou love, honor, and cherish him, In stckness and in healch, in prosperity or adversi=7; and, for saking all others, and the thought of all others, keep thee only unto him so long as ye both shail live? Do you so declare?

4. Wile thou, , have chis woman, to be thy wedded wife, to live together in the holy estate of matrimony? rile thou love her, comfort her, honor and keep her, in sickness and in healch; and forsaking all other, keep thee only unto her, so long as ye bork shall live.

iile stiou, - have tis an. , so be thy wedded husband, to live together in the holy escace of nacrimony? Wilt thou love htm, comfort him, honor and keep him, in sickness and in health; and Eorsaking all others, keep thee oniy unco inin, so long as ye boch shall live? 
5. , do you take this women you hold by the hand to be your lawfully wedded wife? Do you solemily promise before God and these witnesses that you will love, honor, and cherish her in sickness and in health, in prosperity or in adversity, and forsaking all orhers, keep yourself only unto her so long as you both shall live?

, do you take this man whom you hold by the hand to be your lawfully weded husband? Do you solemaly prowise before fod and these Hinesses caat you will love, honor and cherish him and in health, in prosperity or in adversity, and forsaking all others, keep yourself only unto him so long as you both shall live?

6. And now, solemily promising before God and in the presence of these witnesses w111 you, , have this woman, to be your wedded wife, to llve together after God's ordinance in the sacred escace of matrimony. Will you love her in slckness and in health, In prosperity or in adversicy and forsaking all orher, keep you only unco her as long as you borh shall live? Do you so declare?

And will you, , have chis man, to be your wedded husband, 50 live cogether afrer God's ordinance in the sacred escare of matrimony. Will you love, honor, and cherish him, in sickness and in health, in prosperity or in adversicy; and corsaktas all ocher, keep you only unto his as long as you both shall live? Do you so declare?

7. Solemnly pronising before God and in the presence of these Eriends and loved ones, rill you , have =his yonan,

to be your $; i$ ie, to Live cogether accord1ag to God's plan in che sacred estace of natrimony? Will you love, honor, and cherisi her in sickness and in heaith, in prospericy or adversity, and Eorsaking 31 orhers, kaep yourself only unto her as ong as you both shall live? Jo you so declare?

Will you, , have shis man, to be your husband, to live cogether accordiag to God's plan ia the saczed escace of zarzinony? Will you love, honor, and cherisi idin, in sickness and in health, in prospericy or adversicy, and forsaking ail orhers, keep yourself only unto her, so long as you both siall live? Do you so declare?

8. - do you solemnly promise berore God and ziese wicnesses that you ril iove, honor, and cherisi is sickness and in healch, in prospericy or in adversiey, and jorsaking all ochers, keep yourself only unes her, so long as you boch siall live? Do you so declare?

- do you promise - whose hand you hold and bejore chese wiznesses, and bejore God that you will jaithrully and diligenty keep yourself unto him as his lawtul wife, and honor and reverence ill as your husband; to cheertully share rith hil all that the live wisti iles bejore you boch nay have in score--sickness or healch, poverty or wealch, sunshine or shadow, to be all things what God designs a wike so be, God helping you? Do you so declare? 
9. - do you take this woman to be your lawiully wedded wife? Do you solemnly promise before God and these witnesses that you will love; honor, and cherish her in sickness and in health, in prosperfty or in adversity, and forsaktag all others, keep yourself only unto her so long as you both shall live?

' do you rake this man to be your lawiully wedded husband? Do you solemaly promise before God and these witnesses that you wll love, honor, and cherish him in sickness and in bealth, in prospericy or In adverstey, and Eorsaking all others, keep yourself only unto him so long as you both shall live?

10. Do you, witnesses, solemly declare that you will cake, to be your lawful wedded wife, to live cogether affer God's holy ordinance In the sacred estate of matefmony-to have and to hold, to live and to cherish. Erom. this day forward; in sickness or in health, in adversity or in prosperfty, and forsaking all ochers, to keep yourself wholly unto her as long as you both shall live?

Do you, , before God and in the presence of these witresses, solemily declare that you wil take, to be gour lawful wedded husband, to live cogerher afeer God's holy ordiance in the sacred escace of watrimong-to have and to hold, to live and to cherfsh, from this day forward; in sickness or in health, in adversity or In prosperity, and forsaking all ochers, co keep yourself wholly unco hin as long as you boch shall live?

\section{Variacion of Tradictonals}

11. do you choose to rake. to be your wife? To have her lodge with you wherever you lodge. to take her friends as your friencis? Do you trust her as your best earthly friend and rromise to love, to cherish. and to procect her in sickness and in iealth, in prosperity and in adversicy, to be considerace to her happiness in all your plans, and in all things to seek her velfare as your own? Do you pledge yourself to be her husband and so live in all things according to the principles of the gospel of Christ. Do you so promise?

co je your husband? To lodge zith him wherever he lodges, to cake his irlands as your frlends? Do you trust him as your best earthly friend and promise so love, to cherish, and to procect hin in sickness and in health, in prospericy and In adversicy, co be considerace of his happiness in all your plans, and in all things to seek his welfare as your own? Do you pledge yourself to be his rife and so live in all things according to the principles of the gospel of Christ. Do you so promise? 
12. do you solemaly promise bejore God and these witnesses that you will love, honor, and che rlsi in sickness and in health, in prospertigy or in adversicy, and forsaking all orhers, keep yourself only unco her, so long as you both shall live? Do you so declare?

, do you pronfse whose

hand you hold and before these witnesses, and before God that you will falthfullly and dilfgenty keep pourself unto him as his lawiul wife, and honor and reverence him as your husband; to cheerfully share with him all that the Ilfe which lies before you both way have in store--sickness or healch, proverty or wealth, sunshlne or shadow, to be in all things what God designs a wife to be, God helping you? Do you so declare?

13. Do you, , cake loving wife. Do you promise to love and sustain her in the bonds of narrlage from this day forward in stckness and in health, in plenty and in want, efll deach shall pare you, according to God's holy ordinance. Do you pledge this =0 ?

Do you, cake husband, your friend, and your love. Do you promise co love and sustain him in the bonds of marriage from this day Eorward, in sickness and in health, in plenty and in wank, in joy and in sorrow-Eor wisere he goes, you will go, were he ilves you will live, his people will be your people and where he dies you will die. Do you respond and pledge this to ?

\section{: Yon Tradictonals}

14. - Co you cake =his woman, choosing her alone izon all sie world, to je your lawiul and redied wize, and forsaking all orher, keep thee only ever inco her? Do you trust her as your jest earrhIy iziend. and you promise to love, to chertsh, and to procece her in sickness and in health, in prosperity and in adversicy, to be considerace of her happiness in all your plans, to culetvate for her sake all naniy virsues, and in all irings to seek her welfare as you see your own? Do you piecge yourself thus honorable to her, to be her husjand in good faich, and so to live all rhings according to the principles of the jospel of Christ, 50 long as the providence of Goc sinall spare you to eaci other? Do you thus promise.

In like mancer, - do you receive this man to be your lawîl wedded husband? Do you choose him alone, irom all the world, as he has chosen you, and forsaking all others, keep yourself only and ever to him, as your best earthly Eriend? Do you promise to love, to comrort, and honor hin, in sickness and in health, in prosperiey and in adversity, so culizvace for his sake all zonaniy jrace, =o juart his zepucalton, =0 assist $\mathrm{hi}=$ in all his lifework, and in all chlngs to esceen his hapolness as your own? Do you give yourself chus crustfully to him, to be his vile in good Eatth, and so to live in ail things as long as the providence o: God shall spare you so each ocher? Do you rhus promise. 
15. do you take to be your wedder wife, and in the presence of God and these witnesses, do you vow that you wll do everything in your power, with God's help, to make your love for her a growing part of your life? W1Il you be devored and true to her whenever God leads you in His service? W1ll you stand beslde her through whatever life wight bring, will you bend your every energy to sirengthen her towards the kingdom, and you keep her alone as your companton, as long as you both shall Ifve? WILI IOU MARE IHESE PROMISES FAIIHIFULII TO BER?

, do you take to be your wedded husband, and in the presence of God and these witnesses, do you vow that you wll do everything in your power, with God's help, to make your love for him a growing part of your I1fe? W11l you be devored and actentive to him wherev God leads you, wth him, in als service? WIll you stand beside him through whatever life wight bring, Wll you bend your every energy to make him the happy and successful minister that God wants him to be, and wlll you keep him alone as your companion as long as you boch shall live? WIIL YOO MAKE IIESE PROMISES FAITERULIT IO HIM?

16. , you have chosen

as your husband

and our of the concext of 's pledge to you, and in the spirit of this same love, along with your desire to help as his wife escablish this home where you both can concentrace on each ocher' needs, as well as the needs of other people. Do you accept his pledge to you, and do you desire to give to him-cocal self, a verg cender love, a patience that calns, thoughteulness $\mathrm{in}$ word and deed and a vast amount of understanding. Do you respond and pledge this to him?

- you have chosen to be your wife and in the spirit of the 3 fbllcal description of love, do you desire to establish a Christian home, where you can learn to weet 's needs for arfection and love and have your own needs met, where ocher persons. both young and old, can derece serenity and respect. Do you pledge at this time your cocal sel E to be her husband-oto be tender to her in moments of stress and grtef, patient iz tizes of stzain, thoughtzul in small things as well as large, and to endeavor to understand the many facets of your lives and experiences. Do you pledge this to ?

\section{Saying to Each Other}

17. I, , do solemly and sincerely declare that I take you, to be mowiully uedded wife, to love and to chertsin, from this day forfarj, in sickness or in health, in adversity or in prosperis: and forsaking all others, Hill keep mself wholly unco you, so long as we both shall live, and thereto pledge wy word.

I, - do solemly and sincerely declare that I cake you, to je wy Lawrilly wedded husband, to love and $=0$

cherisi from ehis day forward, in sickness or in health, in adversity or in prosperticy, and forsaking all others, will keep myself wiolly unco you, so long as we.both shall live, and chereto I pledge ny word. 
18. I. , do solemnly and sincerely declare that I take

you, , to be my lawtully wedded wife. I promise to love and cherish you from this day forward, in sickness or in health, in adversity or in prosperity. I promise to keep myself wholly unco you, so long as we both shall live.

I, , do soleming and sincerely declare that I cake you, , to be my lawfully wedded husband. I promise to love and cherish you from this day forward, in sickness or in healch, in adversicy or in prosperify. I promise to keep myself wholly unto you so long as we both shall ilve.

19. I, , cake you, to be my loving wife, I promise to love and suseafo you in the bonds of marriare Erom this day Eorward in sickness and in health, in plency and in want, t1ll death shall part us according to God's holy ordinance.

I, , cake you, , to be wy husband, wy Friend, and my love. I prowlse to love and suscain you in the bonds of marriage from this day forward, in sickness and in healch, in plenty and $i n$ want, in joy and in sorrow-for where you go, I will go, where you live I will live, your people will be my people and where you die, I will die. To this end I give you my faith.

20. In the presence of God and our frtends, I take you, to be my wife. In the spizis of the 3lblical descizption of love, I desire to establish a home where I can learn to love you as Christ loved us. I will cherlsh and love you through rhatever life will bring us. I pledge myself to be tender, parient, and thougneful in swall things as weli as large. My greacer desize is that we wight spend ecenity cogecher. I want to be the type of husband to make this possible.

1: $:$ makes me very happy to take you as $2 y$ husband.

God rade you a Find, stzong nan and I tzust you as my jest earthiy Erlend and promise to cherish and love you. I promise co stand beside you - through whatever life mighe bring us and consider your happiness in all ny plans. I rill serfve co bring you hali the happiness that you have brougit ay life already. Nith God as ay helper, I will endeavor to make our home a place where you can cacch a jorecaste of heaven. Wirh a joyful hears I accept your pledge to ane and willingly give you my heart. 


\section{WEDDING INFORMATION FOR THE MINISTER}

1. Wedding Coordinator

2. Audience Stand During Bridal Processional

Yes

No

3. Minister's Clothes

Suit

Robe

Tuxedo

4. Wedding Colors

5. 'Who Gives" Response
a. "I Do"
c. 'We Her Parents"
b. "Her Mother and I Do"
d. Other

6. Vows Number Other

7. Vows
a. Minister says
b. Couple Repeats after Minister
c. Couple says

8. Unity Candle Ceremony

Yes

No

9. Introduction
a. To both parents
b. Couple only
Bride's parent's names
c. Other
Groom's parent's names

10. Prayer Number Other

11. Announce Reception

Yes

No

Place 


\section{Bride's calendar}

A besutiful lomal wedding ukes a minr mum of six monuns to arrange. The follow ing list is cesigned to guide you in taking eare of all details at the oropor time.

\section{SIX MONTHS BCFOAE:}

Discuss wedaing oudget with yout arents. Sulect the tyos of wedating you went.

Decide on moding and reepotun sites.

Determine the number of gueste you ean acsemmodate at both stas.

See elergy member or judge with hanes. plan pecaption. maxa reservations. Croose end ordar your dreas. acesasories. Solect and rogisser enine. sitvor, te. gegin guest lise have tanes do hta. Choose artencanta.

Plan now home. begin shepoing tor it

Send lor honoymoon brochures. consult a travel agent for ideas.

THREE MONTHS BEFOAE:

Comoiete your guest ist.

Orser invitamons and announceminta.

3egin snopping lor trousseau.

Acoress invieavons une innouncement (allow enres to lour weens tor engram ing).

Set cate to orear atrencana' drmasen.

Select a pormut photogradner.

Make an aopointment witn gynocologist to examine you. alscuse sirn centrol.

Make youp noneymoon :eservations.

Plan ceromany. receotion cotals with organise. Honst. eaterne, otc.

\section{ONE MONTH BEFORE:}

Juy ine groom's wedeing silk

Vett your invitations. bu

Crcer Howers for medcing. :eceonon.

tave tinal eress and nescolecs fitung.

-ave corrat taxen.

zioose gits lor your anencants.

Jroer groom's nng.

irrange locging for out-ottown guesta.

Plan your oncesmaics' lunemeon.

Wake olans tor tne renearsal sinner.

Nrite thank-you notes tor gits.

trrange for innouncement in newsoapers.

FNO WEEKS 3EFORE:

Somplete your troussuau.

Jo with your fance 'op maenage lieense.

sirange to transoort atronaanes to crures.

stecx on ceirvery of all ourciasee.

jene announcements to newseader.

Wake an appoinument with natroreser.

Juy your :ugeage: souste enecx noney moon reservauons.

\section{ONE WEEK 3EFORE:}

jogin your noneytrioon sacxing.

-inisn writing your announcements to mast on your recoung =ay.

Jive 3 tinat sstimate of the numoer of -eceotion zuests io tne caterer.

Sive dno/ or arena =ncesmajos' iunceseon.

drrange ronearsal. :all ine weocing jarry.

Dreex on finat cetalls witn Honst. onotogapner. musictans, tic.

Aprange to move osiongings :0 new nome.

<eeo ud with jitt jexnowleogements.

\section{Groom's check list}

The groom coesn't have as many wedding preparastons as the orice. out his duties are imponane the list below spans a six. month period-ine minimum amount of dime needed to plan a formal wedding.

\section{SIX MONTHS BEFOAE THE WEDDING:}

Order bride's engagement. wedding rings. Start maxing out your guest list

Arrange a visit with etergy member. judge.

Discuss with youp lanete how many ushers you'll need (about one for wery so gueses) and oegin to saices them.

Discuss nonoymoon plans with your fiancto und start making transportation and cceommodation resenstion.

If you are traveling abroad. Be sure to up date oasseorts. amenge for visas and check on inoculetions.

THREE MONTHS BEFORE THE WEDOING:

Comblete guest list: grve it to fiances.

Consult tiancen: orcer weding amtr.

Decrde wnom you went as your oest men and usners: invite thom to pordeioats.

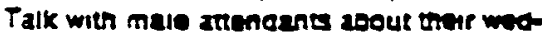
ging andre.

Comolete honoymoon glans: buy tlekete.

ONE MONTH BEFORE THE WEDOING:

Decice on ende's souquet and going-away corsage: caecx wath tiances on coutonnieres for men in the wecoing parry ane notners" earsages.

Piex uo once's nng: eneex engraving.

Arrange lodging tor retatres and usners trom out of town.

Salec: gitt to your sride. amencants.

Make sure recessary cocuments-inal. meateal. anc raligious-ire in srear.

Orcer jloves. ntes. ascots ior all yout atiencants.

Haxe sure iney've orcered inerr own arare.

FWO WEEKS BEFORE THE WEOOIMG:

Maxe a cate wits yout hances :o get the mamage license. (You migm make it a moro festrve oceasion Jy taxing her :o lunea at ner tavonie restaurant)

Checx on arrangements lor ine oacnetor sinner if you are giving it).

drrange witn your =est הan sor transeor:ation :om ins eceotion ine siroor or trom mnerover you are stanning to 'seve on your nonoymoon!.

Douole enecx noneymoon reservations.

\section{ONE WEEK BEFORE THE WEDOING:}

Present gits :o youp atrencants (at the sacnotor sarty).

2amine your oest nan and usners of the ienestsal umo sne jrace. und fill inem in on ronearsat ainner cotalis.

Exolain anv scoc:at seating arrangomonts :o the neac usner.

D.jt the minisier 3 ar iugas s ree in a sealed envelooe and jive it :o je jest man. He will Jenter :e,

Get your joing-3way c:cines ready so you can saance arter the nceotion.

osex tor your soneymoon.

trrange o move serongirgs to new nome.
WHO PAYS FOR WH

THE BRIDE

1. Groom s wecieing eing. if is s touble ring ser

2. Wadding gif ior the groom.

3. Presents for the artendents.

4. Accommodations for her artendents from out =

5. Porsonal storionery

6. Her medicel exeminotion.

7. If the bride wishes. she may assume ony re bilities that bolong treditionally to her family.

\section{THE GROOM}

1. Martroge lieanse.

2. His medical exominotion.

3. The brides engagement and wedding nngs.

4. Gift for the onde.

5. Brees bouquep and going awor corsage ithe fomily moy want to soy ior inisl.

b. Beutonnieres for ine men of the woding ser

7 Flowers ior the nwo mothers.

3. Gioves seseots. or thes cor the men in the n

Q. Gifrs :or ushers snd best man.

10. Acesmmocotions for his besi man and usher

ii. Oorionol: scenelor sinner.

12. Foe for the elergyman.

13. The wodding rio.

\section{BRIOE'S FAMILY}

1. Bnees wedeing smire and sersonal trousseal

2. Necting -nvirorions snd snnounements.

3. The engegement and wealng snorogreon

1. Reniel ior steures, if sav

5. Fyes tor the orgenist. soloist snd sexron.

b. Aisie carser and senoov.

7 :owers :or enures.

3. Bricesmaids sovowers.

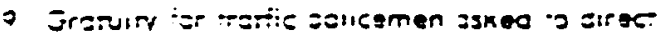

10. irsnsecriemon ior grical serv trom the -

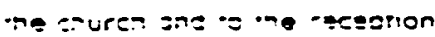

il Er:cesmaras iuncrieon.

i2. Renearsal sinner :if grooms amiv soes no: 13. Entre cest of ine receorion: -enret ji zluo. sesemmocestions: nusie: jowers: food: sil sel ises is jroiessional hero.

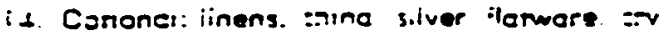
zrner housenolo necsssimes :sr he sree sne jis 15. Corronal: zecxcges =i j: or juests $0:=x \in 0$ jream sn

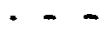

2. Any roveling expenses cno horel auls ior -ree

3. Neccirg jiti ior ine csuole.

t Oononcr:-aneorsor =inner

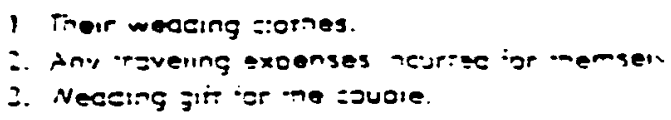

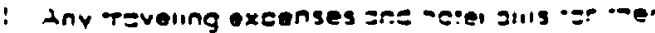

i. veceirs gites o one suote 


\section{BRIDE'S DETAILED CEEC:ZIST}

\section{GE: THESE IHINGS DONE RIGHT AWAY.}

A. Set dace plus some alcernaces for the wedding.

B. Decide on seyle and approximate size of wedding.

C. Reserve wedding chapel or church.

1. Find out all restrictions.

2. Secure a aice dressing zoom for bridesmaid and you - phocos caken heze.

II. ENGAGING IRE SERVICES EOR YOUR WEDDING WIII IAKE A GOOD DEAL OE TIYE - allow plenEY

d. Engage procograpier.

Be sure you can "zork" with him! Let hin know what you do and do not rant.

B. Engage baker.

1. Decide cake style and Elavor. Be sure vegecable shorcenizg is used.

2. Choose cop piece Eo= cake.

3. Kake suze he vill leave a box jor bride's layer.

4. See if the jaker lisarzes ext=a jor Sunday ueddiags - jome do.

c. Engage İorise.

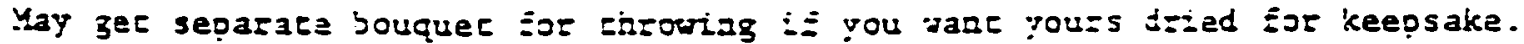

ग. Eagage niniscez.

Let him know rikat you do or do cot vant is the cerenony.

E. Eagage गrzaniss.

Give sais jerson an idea oj rial kind of ausis you vane so have. 3e sure

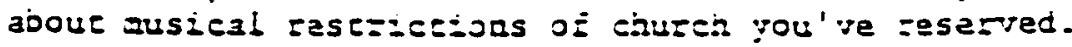

E. Resezre secepciso iali.

Decide on eacs anc nusil tusizg the recept:=on.

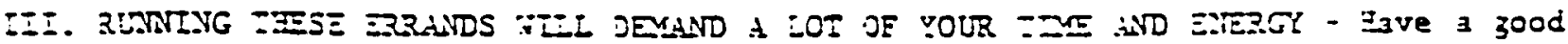
Eziend help rnezo possijle.

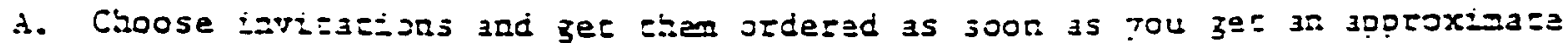

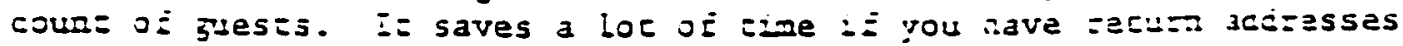

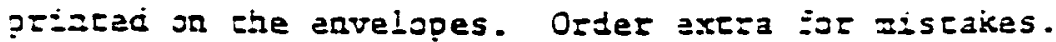

3. Lisc zares and acidesses in 3 注ie jox.

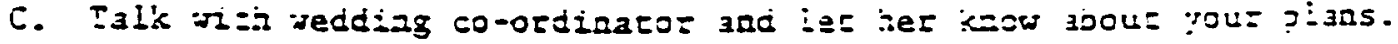

J. Purajase reddizg dress and reil.

三. Choose zowns நor jridesmaids.

E. Gloose zuras ís nee.

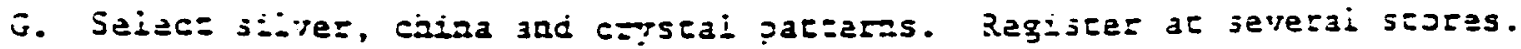

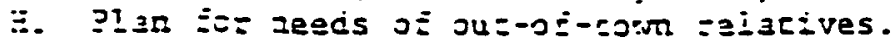

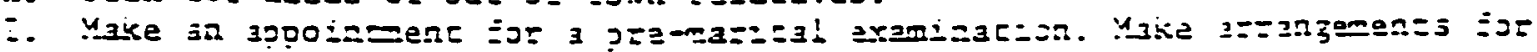

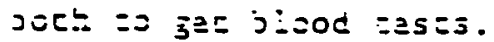

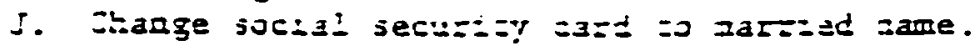

$\because$ Change name on your driver's li=ense.

i. Joen 3 jack accounc iz rour zew same.

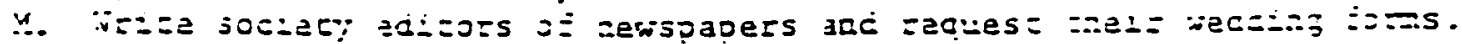

$\checkmark$. Ger zarz:3ge $\vdots$ izense.

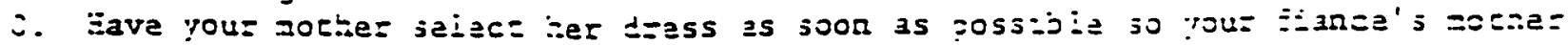
$23 \pi$ zor jers.

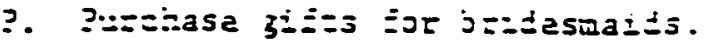

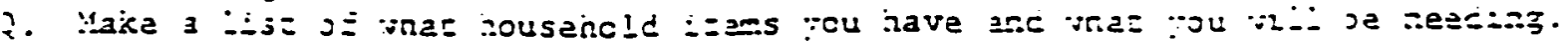

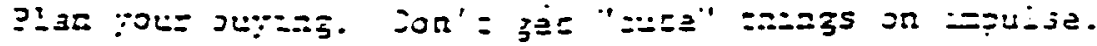


APPENDIX V

FIFTH THROUGH NINTH SESSIONS

Reproduced with permission of the copyright owner. Further reproduction prohibited without permission. 


\section{CHOLERIC}

\section{Emotional Charncteristics \\ Confident in decision-making \\ Strong-willed \\ Determined \\ Optimistic \\ Self-sufficient \\ Fearless and bold}

\section{Relationship to Others}

Does not expect anyone eise to do

Not easily discouraged

Strong leader

Goou judge of peopie

Exhorter

\section{Work and Other Activities}

Good organizer and promoter

Decisive

Quick and bold in emergencies

Keen, quick mind

Great capacity for action

Does not vacillate

Very practical

Stimulates others to work

Thrives on opposition

Sets goals and reaches them

Agenda-oriented something be/she can't do

Motivator of others

Rarely daunted by circumstances
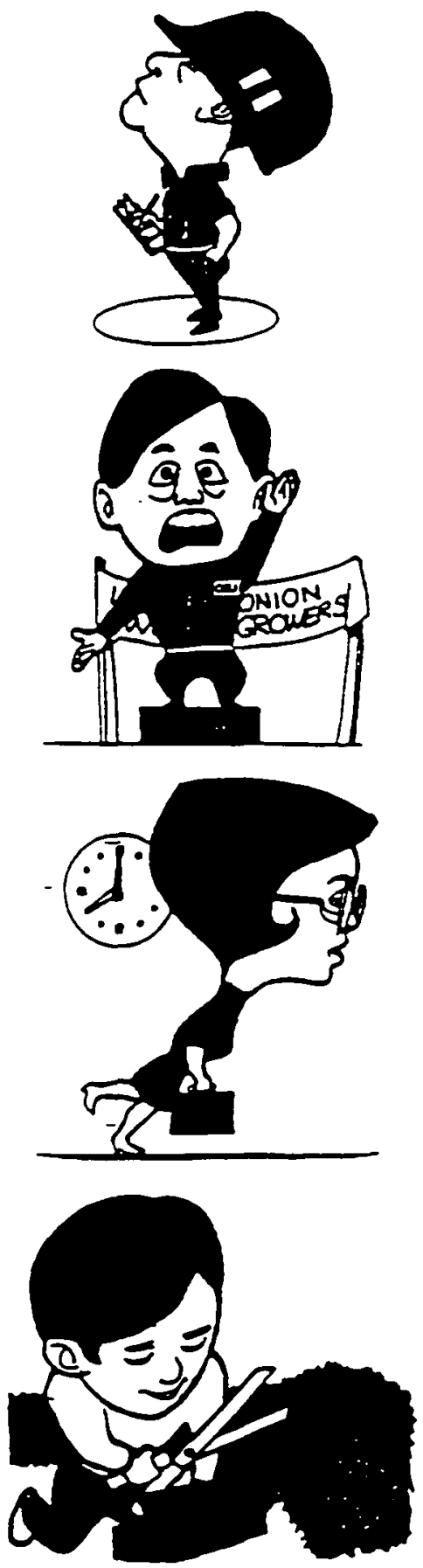

\section{Greatest Needs}

To become sensitive to the needs of others

To confess angry spirit and seek forgiveness of God and others

To be forgiving and toierant of others

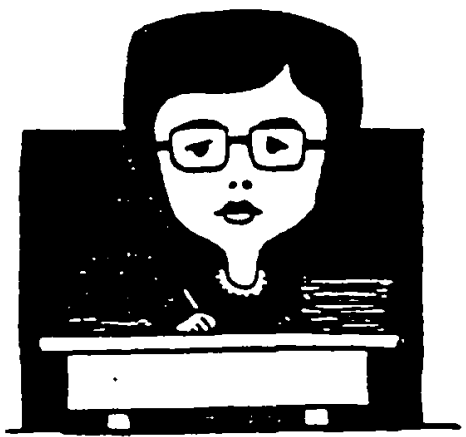

Anger problem which may become violent

Insensitive to needs of others

Unemotional and cold

Litule appreciacion for aesthetics

Unsympathetic and harsh

Disgusted by tears

Lack of compassion

Makes decisions for others

Can be cruel, blunt and sarcastic

Tends to dominate group

Arrogant and bossy

Uses people for own benelit

Unforgiving and revengeiul

Prone to prejudice, bigotry

Haughty and domineering

Overiy self-consident

Crafty

Bored by details, non-anzintical

Opinionated

Forces others to agree to plan of work

Tiresome and hard to please

Only time for own plans or projects

Does not communicate his/her agenda to others

Frustrated when agenda cannot be completed

To develop inner streagth and beaury by quiet hours spent read. ing the Bible and praving

To be more communicative about ideas and plans aith collezgues and companions 


\section{MELANCHOLY}

Emotional characteristics

Loves music and ant

Rich, sensitive nanure

Analytical ability

Emotionally responsive

Deep, reflective thinker

Great appreciation for aesthetics

Empathy for others

\section{Relationship to Others}

Dependable friend

Self-sacrificing friend

Faithful and loyal friend

Makes friends cautiously

Deep feeling for friends

Keepers of memories

Builders of family traditions

Responsive listener

Deeply suirred by ochers' pain

\section{Work and Other Activities}

Strong perfectionist tendencies

Likes detail work

Self-disciplined: finishes what he/she undertakes

Fitted for creative, incellecrual work

Conscientious and thorough

Gifted; genius-prone

Knows own limitations

\section{Greatest Needs}

To overcome critical spirit

To be delivered from self-absorption

To become occupied in loving service for ochers

To develop a thanksgiving spirit
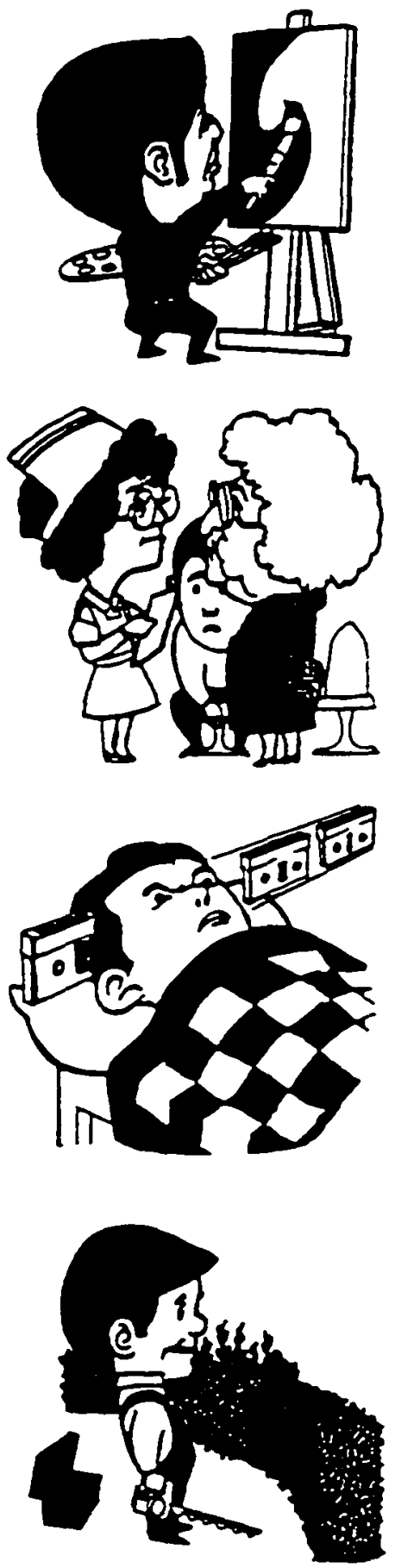

To live a balanced life that includes adequate rest, exercise and a good diet

To consistently spend time in study, meditation and prayer
Moody and gloomy
Pessimistic, frequently looking on the negative

Likes to suffer, martyr

Hypochondriac

introspective to the point of being harmful

Depression

Proud

Critical of other's imperfections

Searches for perfection and judges everything according to own ideas

Fearful of what others think

Suspicious of others

Can erupt into violent anger arer prolonged animosity

Often deeply hurt by others

Will carry a grudge and be revengeful

Dislikes those in opposition

Indecisive

Theoretical and impractical

Tures easily

Hesitant to start a new project

Too much anaiysis; leads to discouragemeat

Gets moody over creations

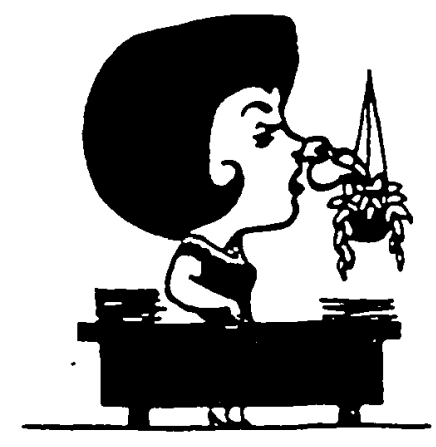

Reproduced with permission of the copyright owner. Further reproduction prohibited without permission. 


\section{PHLEGMATIC}

\section{Emotional Characteristics \\ Calm and dependable \\ Good-natured and casy to get along with \\ Cheerful and pleasant even if doesn't bave much to say \\ Kind-bearted \\ Peace-loving}

\section{Relationship to Others}

Pleasant to be with

Has many friends

Dry, witty sense of bumor

Sofiening and conciliating effect upon others

Constant and faithful

Diplomacic and peacemaker

Good listerer

Faithful friend

Gives advice only when asked

\section{Work and Other Activities}

Works well under pressure

Praccical easy way of working

Conservative

Neat and proficient

Plans work before beginning

Stabilizing influence

Dependable worker

\section{Greatest Needs}

To over come passivity and become involved

To learn to give of self to others
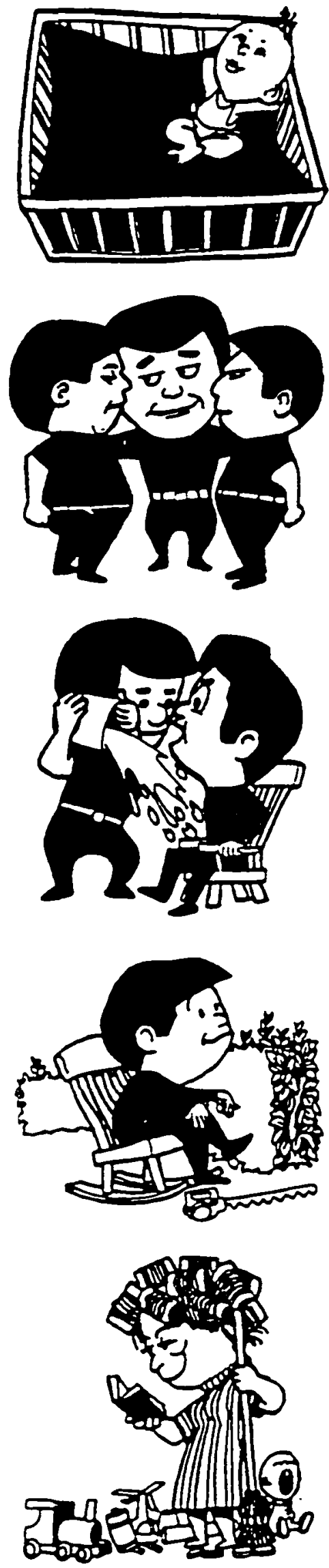

Lacks confidence in self

Pessimistic and feariul

Worrier

Rarely laugas aloud

Passive and indiffereat

Compromising

Self-righteous

Doesn't allow self to get involved Selfish and stingy

Studies people with indifference

Unenchusiastic

Stubbora

Indifferent about others

Teases ochers who annoy himber

Not too openiy cordial

Aritude of superiority

Calm, sereae, uninvolved spectator in life

Slow and lazy

Relucrant leader

Lack of motivation

Indecisive

Overprotects seif from involvement Discourages creativity of others

Opposes change of any kind

To recognize fearfulness as a problem and learn to trust in God with concerns. 


\section{SANGUINE}

Emotional Characteristics

Warm and lively

Charisma

Talkative - never at a loss for words

Carefree - never worries about the future or frets about the past

Great storyteller

Lives in present

Conversation has an infectious quality

Unusual capaciry for enjoyment

Relationship to Others

Makes friends easily

Responsive to people

Enjoyable and optimisuic

Always friendly and smiling to others

Easy to apologize

Tender and sympathetic

Converses with genuine warmth

Shares other people's joys and sorrows

\section{Work and Other Activities}

Makes good first impression

Not bored because living in the present

Gifted in caring for the sick

Easily engages in new plans or projears

Breeds enthusiasm

\section{Greatest Needs}

To be more reliable and dependable

To develop a greater self-disciplined life
Cries easily

Emocionally unpredictable

Restless

Sponraneous anger

Exagerates the truth

Appears phony

Lacks self-control

Emotional decisjons

Impuisive buyer

Naive and childlike

Comes on too strong

Imperuous

Dominates conversacion

Not attentive

Weak-willed and little conviction

Seeks credit and approval

Enjoys people and then forgets them

Makes excuses for negligence

Talks too often about self

Forgets promises and obligations

Disorganized

Undependable: late

Undisciplined

Wastes time talking when should be working

Many unfinished projects

Easily distracted

Falls short of goal

To cultivate genuine humility

To thint before speaking 


\section{City of Toronto}

\section{MLARRIAGE LICENCE REQITREMENTS}

PLEASE NOTE:

1. A mamiage Licence can be issued only to the bride and/or gromm.

2. Both parties MUST sign the Marriage Licence application form.

3. When issuing a Marriage Licence to only the bride or groom, we require a BIRTH CERTIFTCATE OR PASSPORT for the absent person. NOTE: Photocopies are NOT acceptable.

4 Proot of zye is required for all applicants under 21 years of age.

5. There are NO residency, medical, or citizenship requiremer:Ls.

0. If you tave heea divorced within Canda, we require the ORIGNAL or CERTIFiED copy of the Decree Ahsolute or Certificate of Divorce. NOTE: These documents will NOT tre retumed.

1. If you are divorced outside of Canada, piease see the receptionsi tor a FREIGN DIVORCF, KIT.

3. Sixteen and seventeen year olds require both parents consent. Please see receptionist for FORM 6.

9. LICENCE FEE: $\$ 53.00$ (CASH OR CERTIFIED CHEQUE ONIYY payable to City Treasurer)

10. HOURS ISSUED: 8:30 a.m. to 4:15 p.m. (weekdays only)

i1. A Marriuge Licence is valid for use anywhere in Ontario for a penod of three (3) months from the date of issue. A marriage may not be solemnized earlier than the third day following the chate of issuce.

12. Civil ceremonies may he arranged through the Provincial Court, 00 Quien Street West. Romm 14. Toronto. Ontario. Tel: $327-5826$.

NOTE: APPOINTMENTS MUST BE BOOKED IN PERSON IVITH YOUR MARRIAGE LICENCE. 


\section{APPENDIX VI}

\section{TENTH SESSION}

Reproduced with permission of the copyright owner. Further reproduction prohibited without permission. 
WEDDING CEREMIONY

$$
\text { of }
$$

CHERYL-ANN ALICIA ST. IILLAIRE

W'AY'NE OLIVER IVILLAMIS

Sunday July 19.1992 a1 $2.00 \mathrm{pm}$.

Kingsview Village S. D. A. Church

Prelude

Processional

Cannon

Bridal Processional

The Prince of Denmark's Mlarch...

Lighing of Candles

Solo

Scripinre

Gen. 2:24

Col. 3:12.14

1 Cor. 13:4-7, 13

Prayer

Homily (Dedicased 10 Cheryl)

Homily (Dedicased 10 Wayne)

Exchange of wedding vow

Solo... Lord's Prayer

Ligluang of Unity Candles

"From This Day on, We are One."

\section{Prayer of Consecruion}

Signing of Register

Musical Selection

All I Ask of You Duertimbito

P'rescintation of Mir. \& Alrs. Willllams

\section{Recessional}

Wedding htarch... Mendeleshonn

Alan Forde

Madge Corbin

Marie Lyder

Pasior Earl Cameron

Pasior Earl Cameron

Pasior Brian Juriansz

Pastor Steve Cassimy

Pastor Brian Juriansz

Marie Lyder
BRIDAL ENSAAIBLE

Minlsiers

Pastor Brian! Juriansz

Pasior Earl Cameron

Pastor Steve Cassimy

Pastor Frankie Lazarus

IARLNTS

Cluire St. Hillaire

Narvello St. Hillaire

Afads' Corbin

Mald of llunour

Leslie Lawrence

Bridesmaids

Eslyn Siewar

Carolyn Corbin

Ayaruia Lanbern

Indira Ranuaj

Sesl Man

Gary Mlurray

Groomsmen

Wally Lyder

Neil St. Hillaire

Richard Siewart

Chris St. Hillaire

Flower Girls

Alicia Si. Hillaire

Rence Ali

Bible Boy

Ryan St. Hillaire

Allendants

Carmelita St. Hillaire Suzelle Hall

Lesa Lawrence

Mtusiclans

Man Forde

Mrarie Lyder

Diverumento

Tu our beloved fiamily and Friends We thank you each and every one for joining us this day

you've added 10 our huppeness

In a very special way

And as the years shall come and o'o

Our dreams will give us pleasure

And bring you back 10 us again

In memories to treasure 

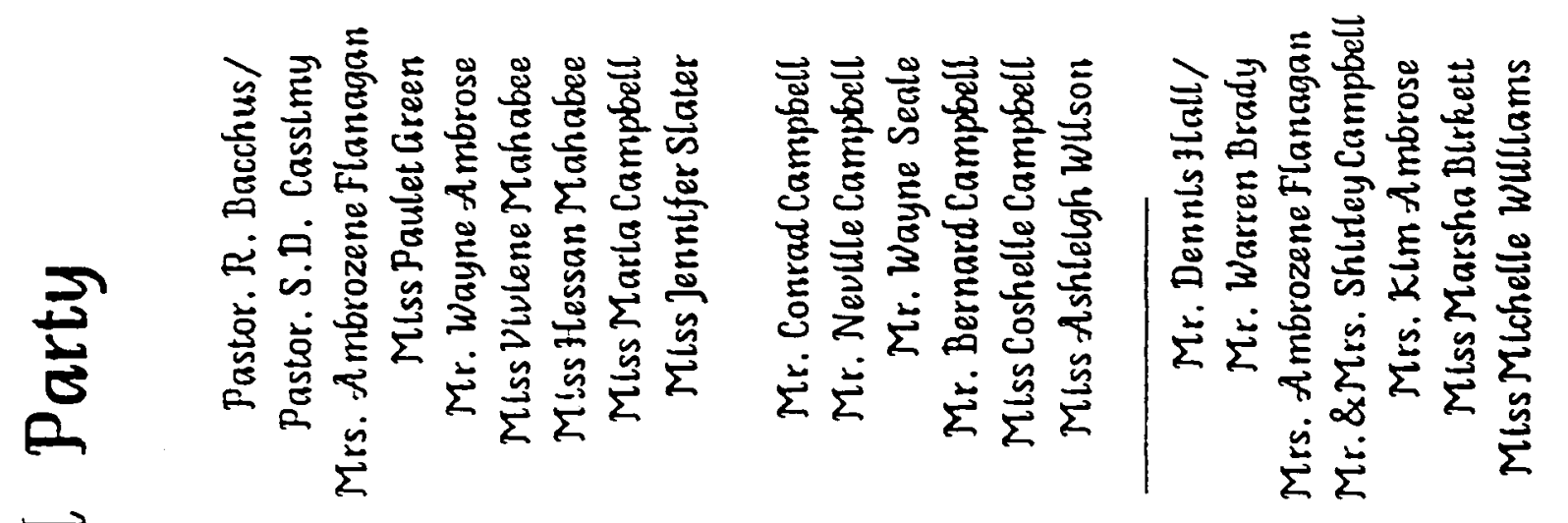

它
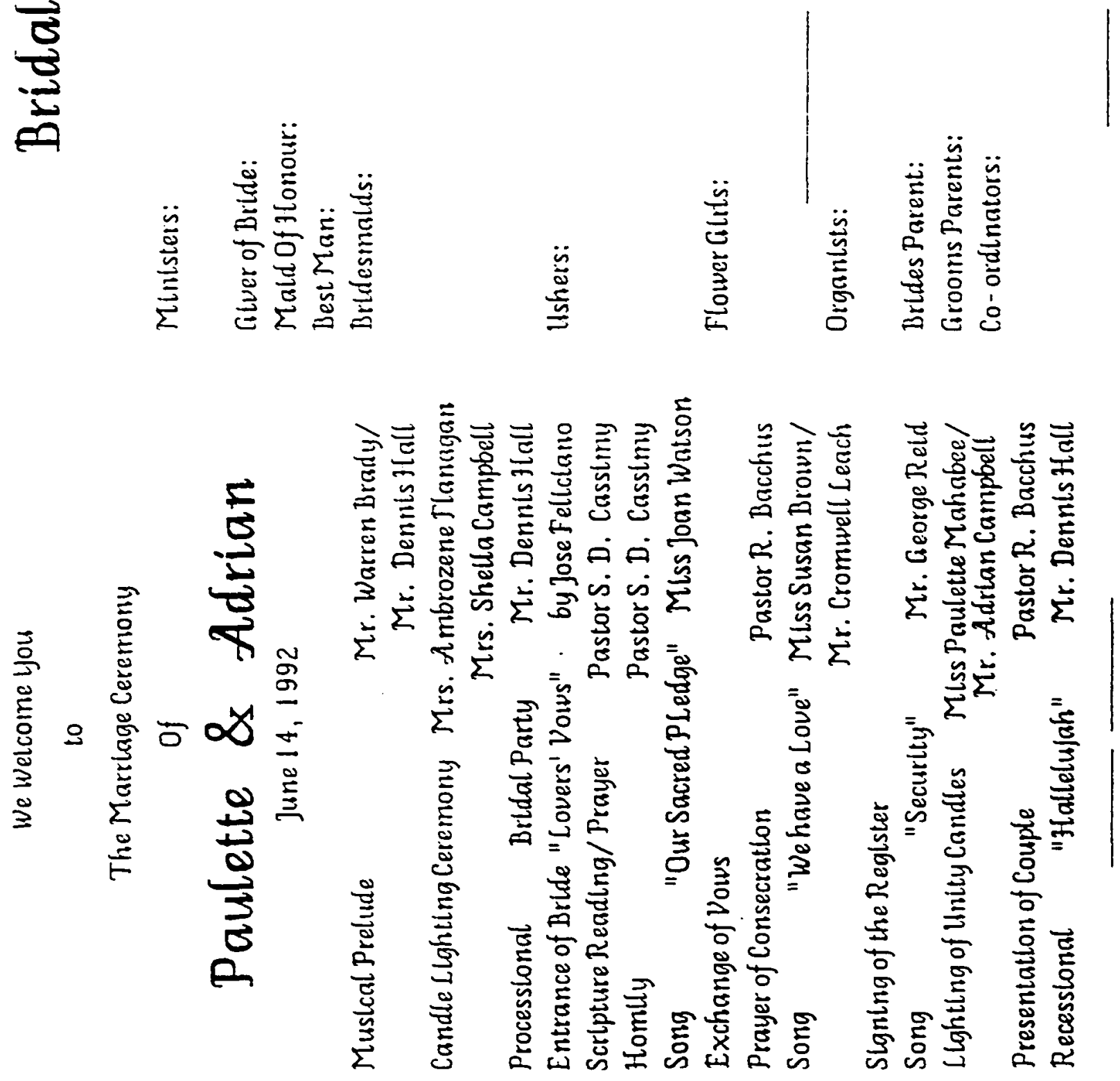
This Wedding Service is

\section{dedicated to the late}

\section{Mr. Elton Noel}

\section{(father of the Groom)}

Officialing Ministers
Groom's Morher
Bride's Uncle
Moid of Illunour
Uesiman
Organist
Vocatist
Co-orvinalur
Rung Bearct
Ushers

\section{OHIER (ON SLRVICL}

Crigan firclude

Procissiondat

Ne lisulthe Inombuts

II nare nulthng"

Mlumenil of silense in Mlenumb

uf the Ialle MIr. I.llun Nuel
Pasior SIeve Cassimy Passor Wayne Marlin

Mrs Persis Noel

Mr. Ilillon Hisutus

Miss Marie Ihomas

Mr Grallam Reis

Mr. Franhic Limmans

Miss Client Josepin

Mrs. Cherre. Ann Nuci

Mr. Darren lisun

Mr. Decion Joseph Mi Jason Nocl
Pl.uslur Marin!

Pisslur Mintllon

Pintur (ansiil)

IIIIde A Ginnin

Vomen bl lave

fintur cassing

Mr Iranbic I:minum

Mercssium.1

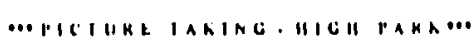

Sie M.p. Iinilused

RECEITION

Misiress ol Ceremonics

linirance of Bridal Panty

Intıo of Brive's lamuly

Iniro of Grouni's lanilly

Dinner l'(s)er

UINNEK

Musical Selecinun

lousl to Bride

luasi 10 Circum

luast to Bride \& Groum

Gither Toasis

Clusing Toust

Cullung of the Cahe

Opening Lance

Ihrowing of the Itouquel

Ganter Sheduing \& Throwing
Miss Carla Tlounas

- llere and Now.

Mr. Ilillon 'Thumas

Mrs l'enis Noel

I'aslur Wayne Martin

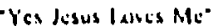

Mrs. l'eras Noc

Mr. Girsham Reid

Well Wislicis

Mr. Andy Noel

-When I liall In love

Poner of luve" 


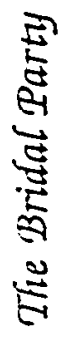
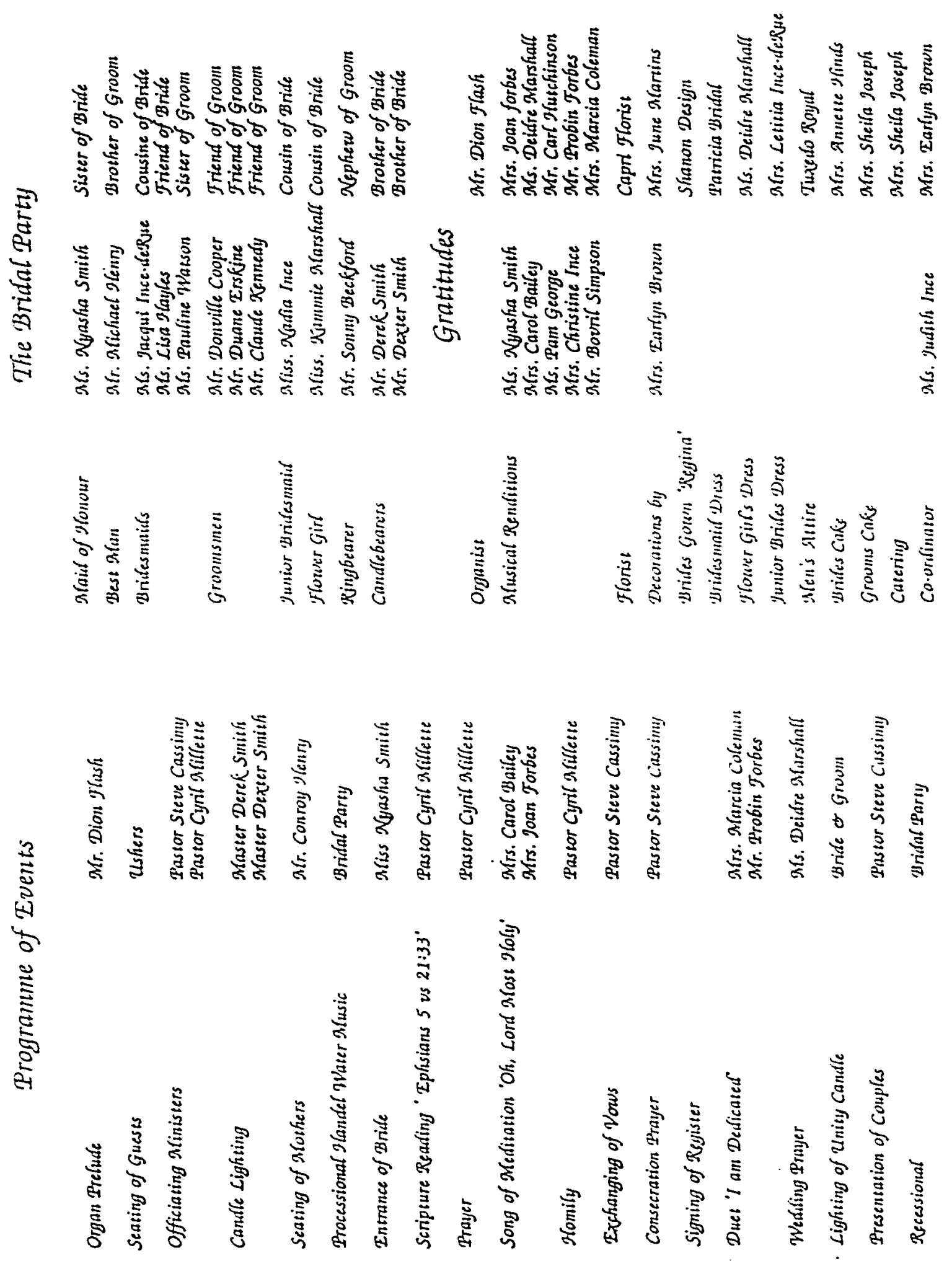


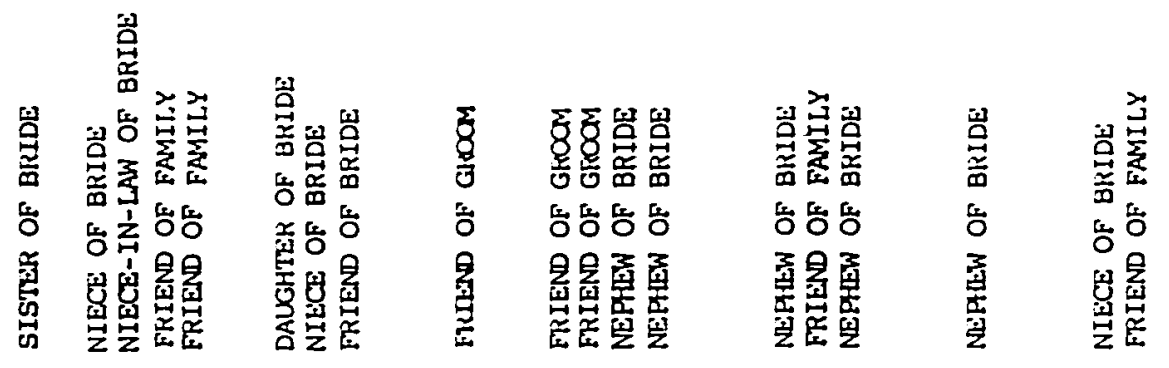
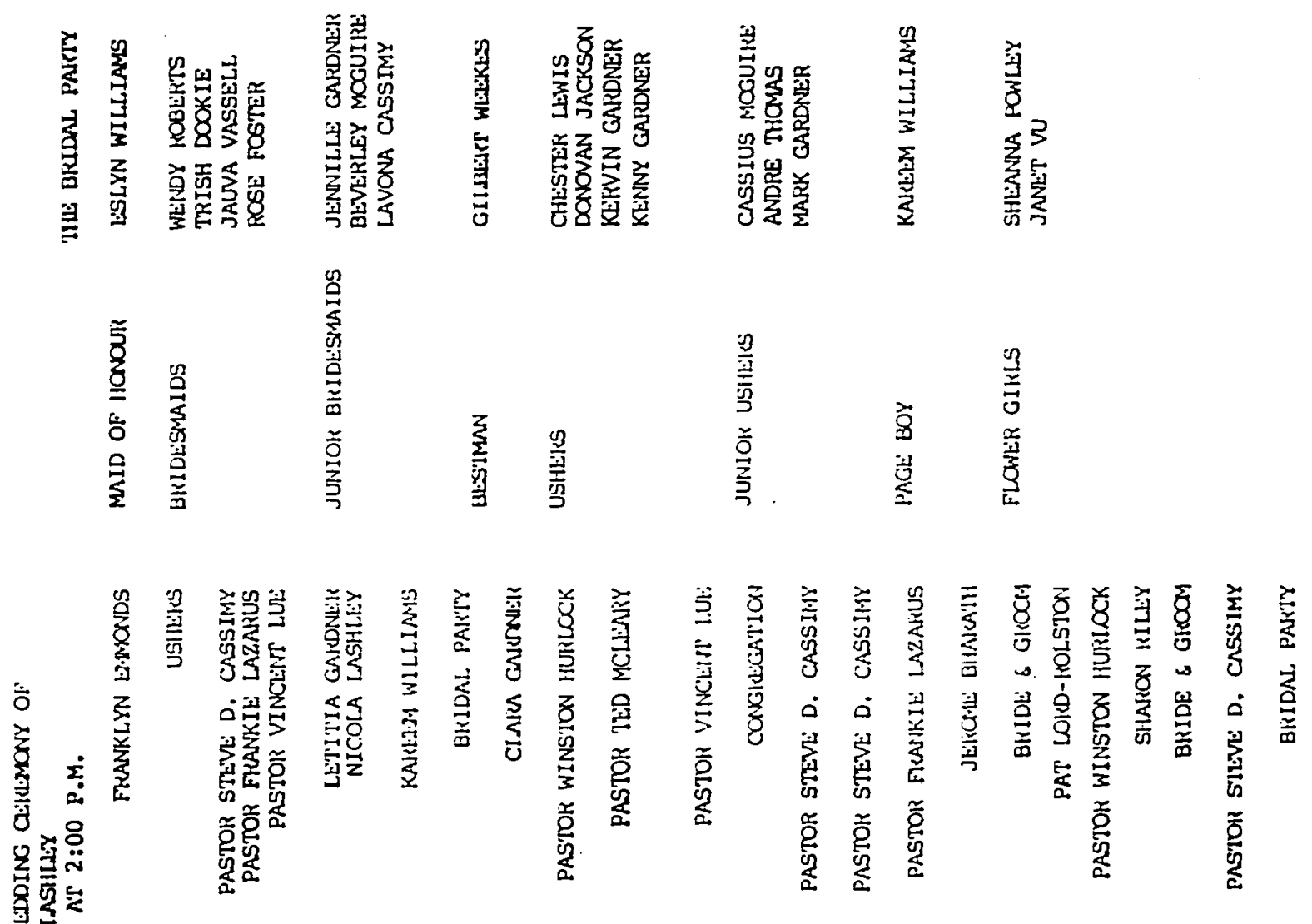

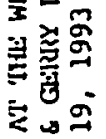

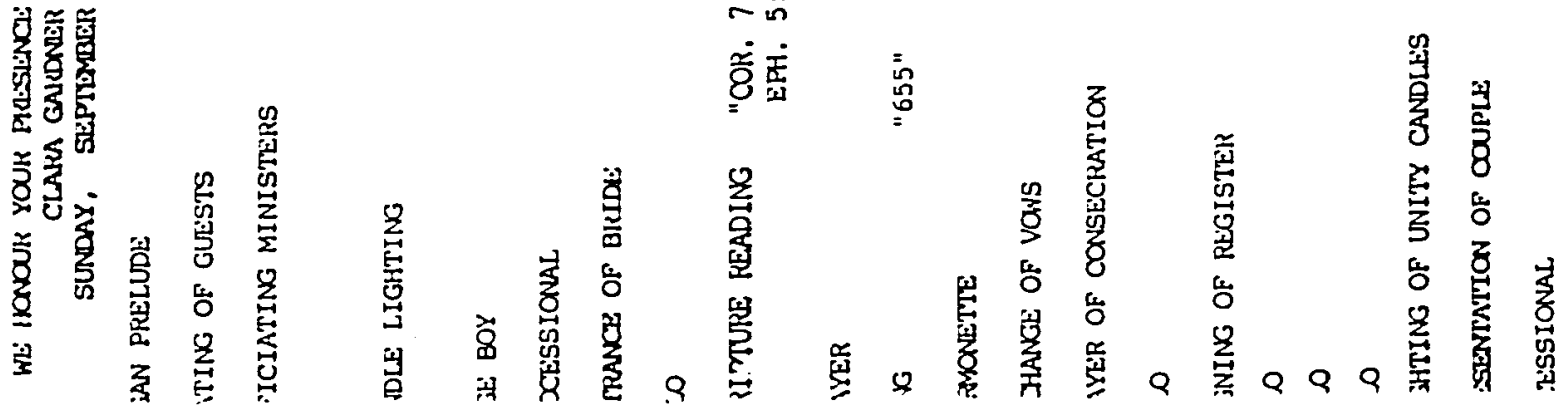


APPENDIX VII

ELEVENTH SESSION

Reproduced with permission of the copyright owner. Further reproduction prohibited without permission. 
APPENDIX VIII

Reproduced with permission of the copyright owner. Further reproduction prohibited without permission. 


\section{A QUESTIONNAIRE FOR METRO TORONTO SDA PASTORS PREMLARITAL EDUCATION}

1. About how many weddings do you perform yearly?
Circle a number
$123+56789101112$

2. Do you have a definite marriage preparation program for your congregation?
Check one answer
Yes $\square \quad$ No $\square$

3. When do you begin your marriage preparation?
Check one: 6 mths before
4 mths before
2 mths before
1 mith before
not at all
inths betore
$\square \quad$ later

4. How many interviews do you conduct before the marriage?

Circle one number $\quad 123+5673910$

5. How much time do you spend in each of the marriage preparation interviews?

$\begin{array}{llll}\text { Check one answer } & \text { more than } 2 \text { hrs } \square & 2 \text { hrs } \square & \text { l's hrs } \\ & 1 \text { hr } \square & 1 \leqslant \text { hr } \square & \text { less } \square\end{array}$

6. Do you feel that the church has a detinite responsibility in prepariny people tor marriage?

- Check one answer Yes $\square$ No $\square$

7. Do you feel it is necessary as a pastor that you conduct a program of premarital education?
Check one answer
Yes $\square$
․o $\square$

8. What do you consider as the most important iopics to be discussed in the intervicivs?

Please circle the numbers chosen

$\begin{array}{ll}\text { 1. } & \text { Selecting a life partner } \\ 2 . & \text { Values } \\ 3 . & \text { Love } \\ \text { 4. } & \text { Religious beliefs } \\ \text { 5. } & \text { Roles and responsibilities in marriage } \\ 6 . & \text { Communication } \\ \text { 7. } & \text { Conflict resolution } \\ \text { 8. } & \text { Goals } \\ \text { 9. } & \text { Feelings } \\ \text { 10. } & \text { Expectations } \\ \text { 11. } & \text { In laws } \\ \text { 12. } & \text { Finances } \\ \text { 13. } & \text { Sexuality } \\ \text { 14. } & \text { Family planning } \\ \text { 15. } & \text { Health and habits } \\ \text { 16. } & \text { Family background } \\ \text { 17. } & \text { Remarriage }\end{array}$

\begin{tabular}{|c|c|c|c|c|c|c|c|}
\hline Vot neces & ssary & & & & & sol & \\
\hline 1 & 23 & 4 & 56 & 7 & $s$ & 9 & 10 \\
\hline 1 & $=3$ & 4 & 56 & 7 & $s$ & 9 & 10 \\
\hline 1 & 23 & 4 & 56 & 7 & 8 & 9 & 10 \\
\hline 1 & 23 & 4 & 56 & 7 & 8 & 9 & 10 \\
\hline 1 & 23 & 4 & 56 & 7 & 8 & 9 & 10 \\
\hline 1 & 23 & 4 & 56 & 7 & 8 & 9 & 10 \\
\hline 1 & 23 & 4 & 56 & 7 & 8 & 9 & 10 \\
\hline$i$ & 23 & 4 & 56 & 7 & $S$ & 9 & 10 \\
\hline 1 & 23 & 4 & 56 & 7 & 8 & 9 & 10 \\
\hline l & 23 & 4 & 56 & 7 & 8 & 9 & 10 \\
\hline & 23 & 4 & 56 & 7 & 8 & 9 & 10 \\
\hline$!$ & 23 & 4 & 56 & 7 & 8 & 9 & \\
\hline 1 & 23 & 4 & 56 & 7 & 8 & 9 & 10 \\
\hline 1 & 23 & 4 & 56 & 7 & 8 & 9 & 10 \\
\hline 1 & 23 & 4 & 56 & 7 & & 9 & \\
\hline 1 & 23 & 4 & 56 & 7 & & 9 & \\
\hline 1 & 23 & 4 & 56 & 7 & 8 & 9 & 10 \\
\hline
\end{tabular}




\section{TORONTO PERTH AVENUE \\ PREMLARITAL EDUCATION EVALUATION}

As you reflect on your Premarital Evaluation, please circle the number that best indicates your response.

$$
\begin{aligned}
& \text { 1 - Extremely helpful } \\
& 2 \text { - Moderately helpful } \\
& \text { 3- Neither helpful or unhelpful } \\
& \text { 4- Moderately unhelpful } \\
& \text { 5- Extremely unhelpful }
\end{aligned}
$$

1. The presentations by wedding resource professionals.

2. The video, "Before You Say I Do."

3. The information gained from the Inventory.

4. The Fears of Marriage Worksheat.

5. The reading materiais.

$123+5$

6. The Temperament Inventory.

$1 \div 3+5$

7. Guidelines for Wedding Ceremonies.

8. Wedding Pravers.

$123+5$

9. Wedding Vows.

$123+5$

10. Bride's Calendar.

$123+5$

11. Groom's Checklist.

$123+5$

12. What suggestions can you share for improving the premartal educational prouram? 


\section{BIBLIOGRAPHY}

Reproduced with permission of the copyright owner. Further reproduction prohibited without permission. 


\section{BIBLIOGRAPHY}

Barber, Ray E. Marriage and the Family. 2d ed. New York: McGraw-Hill Book Co., 1953.

Blitchington, Peter, and Robert J. Cruise. Understanding Your Temperament. Berrien Springs, MI: Andrews University Press, 1979.

Bullock, Henry M. The Pastor's Manual for Premarital Counseling. Nashville: Abingdon Press, 1958 .

Christensen, H. T. Handbook of Marriage and the Family. Chicago: Rand-McNally, 1964.

English, O. Spurgeon, and Gerald H. J. Pearson. Emotional Problems of Living. New York: W. W. Norton, 1955.

Estadt, Barry K. Premarital counseling. Englewood cliffs, NJ: Prentice-Hall, 1983.

Eyrich, Howard A. "A Premarital Counseling Manual." D.Min. project, Western Conservative Baptist Seminary, 1976.

Flowers, Ron. "Good Marriages Don't Just Happen." Ministry, March 1982 .

. "Togetherness, Oneness, Joy." Insight, June 1979 .

- Unpublished manuscript. Silver Spring, MD: Department of Christian Ministry, General Conference of Seventh-day Adventists, January 1994.

General Conference of Seventh-day Adventists (Washington, DC), Minutes of Meetings of Annual Council Committee, October, 1978 .

General Conference of Seventh-day Adventists (Washington, DC), Minutes of 1984 Annual Council of the North American Division, 55.

Good, Robert J., and Robert Ziegfeld. After You Say "I Do". Garland, TX: Haughton Publishing Co., 1986. 
"Guidelines for Wedding Ceremony." Unpublished Ms, Perth Avenue Seventh-day Adventist Board, rev. ed., May 1992 .

Hill, Gerald Kingsbury. "Premarital Counseling Practices and Attitudes Among Ministers of the Methodist Church." Ed.D. dissertation, Columbia University, 1969 .

Morris, J. Kenneth. Marriage Counseling, A Manual for Ministers. Englewood Cliffs, NJ: Prentice-Hall, 1965.

Murray, Don. "Adventist Engaged Encounter Continues at Andrews." Insight, September 1981.

Murray, Don, and Sue Murray. "Witnessing Projects and Their Resources Seminar." Unpublished manuscript, Andrews University, June 1992.

Olson, David H., David G. Fournier, and Joan M. Druckman. Prepare Enrich Counselor's Manual. Minneapolis: Prepare-Enrich, 1982 .

Osborne, Elliot. "Development of Coping Mechanism Seminar for Single Parents Within a Seventh-day Adventist Context." D.Min. project report, Andrews University, 1989.

Rutledge, Aaron L. premarital Counseling. Cambridge, MA: Schenkman, 1966.

Seventh-day Adventist Church Manual. Washington, DC: General Conference of Seventh-day Adventists, 1990.

Seventh-day Adventist Manual for Ministers. Washington, DC: Review and Herald Pub. Assn., 1977.

Stahmann, Robert F., and William J. Hiebert. Premarital Counseling. Lexington, MA: Lexington Books, D. C. Heath \& Co., 1980.

Standish, Colin D. "The Pastor and Premarital Counseling." Ministry, March 1976.

Tingue, Arthur M. "The Minister's Role in Marriage Preparation and Premarital Counseling." Marriage and Family Living 20 (February 1958).

Truxel, Andrew G., and Francis E. Merrill. Marriage and the Family in American culture. New York: PrenticeHall, 1953 . 
White, David H. "Development of the Participant's Manual for a Divorce Recovery Seminar." D.Min. project report, Andrews University, 1986.

White, Ellen G. Adventist Home. Washington, DC: Review and Herald Publishing Association, 1980.

- Child Guidance. Washington, DC: Review and Herald Pub. Assn., 1982.

- Messages to Young People. Washington, DC: Review and Herald Pub. Assn., 1958.

- Ministry of Healing. Mountain View, CA: Pacific Press Publishing Association, 1942.

Wright, H. Norman. Premarital counseling: A Guide for the Counselor. Rev. ed. Chicago: Moody Press, 1982. 